\title{
Role of Central Insulin-Like Growth Factor-1 Receptor Signalling in Ageing and Endocrine Regulation
}

\author{
Lorna Moll, Johanna Zemva and Markus Schubert \\ Center of Endocrinology, Diabetes and Preventive Medicine
}

Germany

\section{Introduction}

Insulin-like growth factors (IGFs) are, besides other mechanisms, controlled by growth hormone $(\mathrm{GH})$ secretion and there are at least two different IGFs: IGF-1 and IGF-2. IGFs regulate various cellular processes e.g. survival, differentiation and proliferation (McMorris et al. 1986; McMorris \& Dubois-Dalcq 1988; Mozell \& McMorris 1991).

Growth hormone, which induces IGF-1 secretion from the liver, is generated in the anterior pituitary and regulated by the hypothalamus via growth hormone releasing hormone (GHRH) and growth hormone inhibiting hormone (GHIH) (Jansson et al., 1985; Carlsson \& Jansson 1990). IGFs in the brain are synthesised de novo or transported across the blood brain barrier (BBB) and seem to induce a variety of effects on the central nervous system (CNS). So far, the exact transport mechanisms of IGFs into the brain are not fully understood (Duffy, Pardridge, and Rosenfeld 1988).

In the rodent brain, IGF-1 is mainly expressed in neuron-dense regions like the hippocampus, striatum, thalamus, hypothalamus and olfactory bulb (Rotwein et al. 1988; Bondy et al. 1990; Garcia-Segura et al. 1991). Accordingly, the insulin-like growth factor-1 receptors (IGF-1Rs) are mainly found in the olfactory bulb, cerebellar cortex and granule cell layer of the dentate gyrus (Rotwein et al. 1988; Bondy et al. 1990; Bondy and Lee 1993; Werther et al. 1990). However, the function of IGF-1R mediated signals in the central nervous system (CNS) is still under investigation.

After binding of IGF-1 to the IGF-1R, a signalling cascade is activated which leads to recruitment and subsequently phosphorylation of intracellular adaptor proteins, the so called insulin receptor substrates (IRS) (Jacobs et al. 1983; Rubin et al., 1983; Sun et al. 1991; Lavan et al. 1997; Lavan et al., 1997). Via these adaptor proteins, the MAP kinase (MAPK, mitogen activated protein kinase) cascade, as well as the phosphatidylinositide(PI)3-kinase signalling pathway, is turned on leading to protein kinase B (PKB/AKT) activation, which phosphorylates forkhead box $\mathrm{O}$ transcription factors (FoxO) causing their nuclear export (Stokoe et al. 1997; Alessi et al. 1996; Partridge \& Bruning 2008). FoxO mediated transcription is involved in cell proliferation, differentiation and oxidative stress defence (Clark et al. 1993; Brunet et al. 1999; Dijkers et al. 2000; Dijkers, Medema, Pals et al. 2000; Medema et al. 2000) suggesting a function of FoxO during development and cellular stress response. 
Recently, the function of the IGF-1R signalling pathway in neurons has been investigated using different model organisms like worms and flies as well as conventional and conditional mutagenesis in mice. These experiments revealed possible functions of IGF-1 mediated signals in endocrine regulation, longevity, protein turnover and in the pathogenesis for ageing-associated diseases e.g. Alzheimer's Disease (AD). The current article discusses the mechanisms of regulation and the physiological as well as a possible pathophysiological role of IGF-1 mediated signals in the CNS.

\section{The GH/insulin-like growth factor system}

\subsection{The somatotropic system}

Growth hormone (GH, somatotropin) is produced in the anterior pituitary by certain specified cells and regulated via the hypothalamus by the growth hormone releasing hormone (GHRH, somatoliberin), the growth hormone inhibiting hormone (GHIH, somatostatin), but also by suppression of the short loop negative feedback of GH itself (Jansson, Eden, and Isaksson 1985; Carlsson and Jansson 1990).

The GH-producing cells of the anterior pituitary, also called somatotropes or somatotroph, form $30-40 \%$ of the anterior pituitary (Gage et al. 1996). These cells require transcription factors of the POU-family (Mullis 2010) including the homeoproteins Pit-1 and Prop-1 (prophet of Pit-1) for normal embryonic development and differentiation (Mullis 2005) as well as for GH expression. The expression of these transcription factors and therefore the differentiation of the somatotroph are controlled by GHRH producing neurons of the hypothalamus. Additionally, GH-release in the pituitary is inhibited by serum IGF-1 and enhanced by serum ghrelin (Wortley et al. 2005; Zigman et al. 2005) (Figure 1).

In the periphery, GH mainly influences growth and development via IGF-1. IGF-1 and IGF-2 can act endocrine, paracrine and autocrine (Cohick and Clemmons 1993; Stewart and Rotwein 1996; Mohan, Baylink, and Pettis 1996; Butler and LeRoith 2001). Additionally, there is a truncated form of IGF-1, Des(1-3)IGF-1, which lacks the tripeptide Gly-Pro-Glu at the N-terminus probably resulting from post-translational cleavage of IGF-1. Des(1-3)IGF-1 is mainly expressed in brain and active in lower concentrations than un-truncated IGF-1 (Ballard et al. 1996; Francis et al. 1988; Carlsson-Skwirut et al. 1989; Ogasawara et al. 1989). Studies on hypoxic-ischemic brain injuries in rats suggest that the tripeptide fragment has neuroprotective properties and influences neuronal activity (Guan et al. 1999).

Circulating IGF-1 is mainly produced in the liver, but both IGF-1 and IGF-2 are expressed in many non-hepatic tissues (Cohick and Clemmons 1993; Stewart and Rotwein 1996; Butler and LeRoith 2001). The most important effects of IGFs are cell proliferation and differentiation, skeletal growth and mineralisation as well as the development and function of the reproductive organs and the central nervous system (CNS) (Duan and Xu 2005).

GH is secreted pulsatile in rodents as well as in humans (Jansson, Eden, and Isaksson 1985; Frohman and Jansson 1986; Giustina and Veldhuis 1998) and follows a circadian pattern with one major peak after falling asleep. There is a sexual dimorphism in GH secretion, which is more dominant in rodents than in humans (Jansson, Eden, and Isaksson 1985; Tannenbaum and Martin 1976). In females, the GH secretory pattern seems to be less regular compared to males (Giustina and Veldhuis 1998), with higher basal interpulse GH levels, more frequent but lower amplitude pulses and a lower major nocturnal GH pulse (Jaffe et al. 1998; Jessup et al. 2003). Spontaneous and GHRH-stimulated GH secretion is suppressed more efficiently by IGF-1 in men than in women (Ohlsson et al. 2009) suggesting that also 
sex steroids interfere with GH secretion (Veldhuis et al. 2008, 2009; Leung et al. 2004). Body growth is influenced more efficiently by GH if it is applicated in a pulsatile fashion than applied continuously (Jansson, Eden, and Isaksson 1985; Clark et al. 1985). This might be due to a higher induction of IGF-1 expression in growth plates and skeletal muscles by pulsatile GH, whereas continuous GH secretion stimulates liver IGF-1 expression and serum IGF-1 levels at least as well as a pulsatile GH release (Isgaard et al. 1988; Bick et al. 1992). Therefore, liver-derived IGF-1 is not essential for body growth itself. This effect might be achieved by locally produced IGF-1 and/or other factors (Ohlsson et al. 2009).

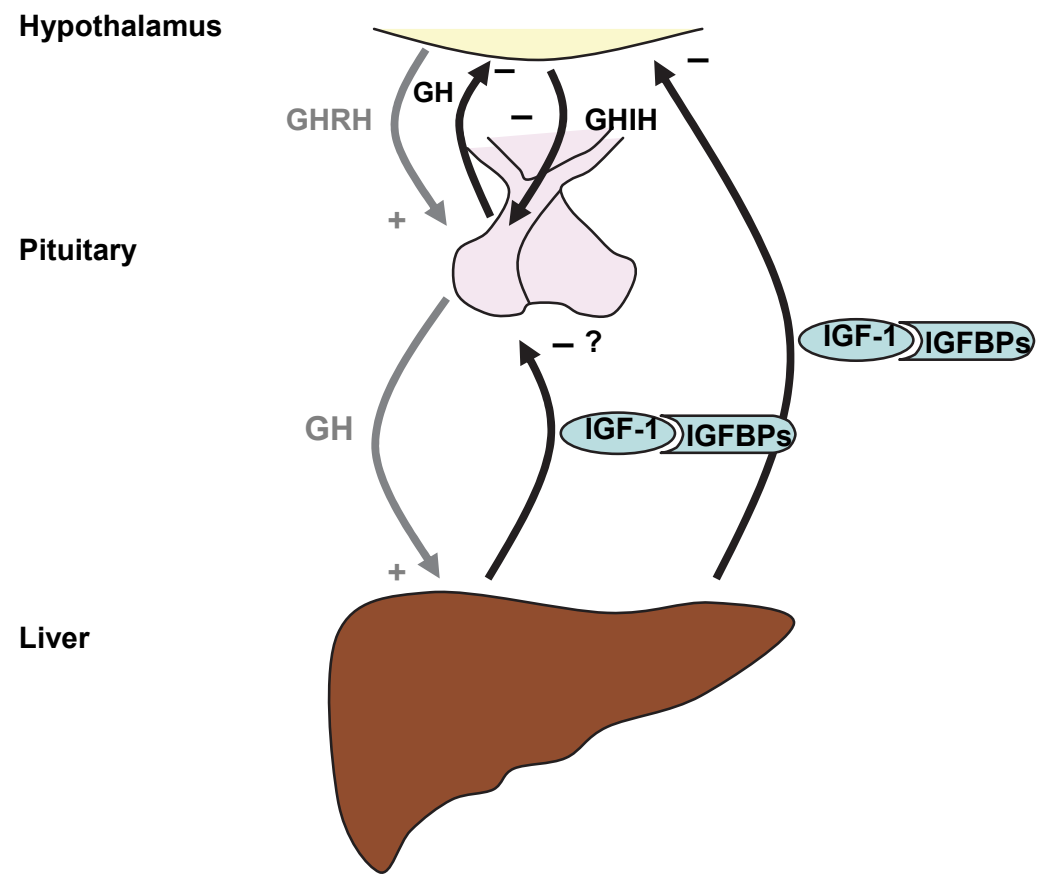

Fig. 1. GH/ IGF-1 system

Growth hormone releasing hormone (GHRH) and growth hormone inhibiting hormone (GHIH) are produced in neurons of the hypothalamus and transported via the hypothalmopituitary portal vein system to the anterior pituitary where they regulate growth hormone (GH) secretion and expression. GH stimulates insulin-like growth factor-1 (IGF-1) production in the liver. In addition, free IGF-1 serum levels are regulated by binding to the insulin-like growth factor binding proteins (IGFBPs). A short negative feedback loop of GH, as well as a negative feedback mechanism of IGF-1 on the hypothalamus and possibly on the anterior pituitary, determines serum IGF-1 levels.

Mouse models with tissue specific IGF-1 inactivation indicate that normal longitudinal bone growth is maintained by local bone-derived IGF-1 (Sjogren et al. 1999; Yakar et al. 1999). However, several other phenotypes, for example the one observed in the liver IGF-1 
deficient (LID) mouse, suggest that locally derived IGF-1 cannot fully replace liver-derived IGF-1 function and vice versa.

A lacking negative feedback of liver-derived IGF-1 on GH secretion leads to a compensatory increase in serum GH levels in mice (Yakar et al. 1999; Sjogren et al. 1999) and also in humans (Veldhuis et al. 2001). Hence, the phenotype of the LID mice might either arise directly or is mediated by the elevated GH-levels. LID mice show an increased expression of pituitary GHRH- and ghrelin-receptors indicating that at least some action of up-regulating GH secretion influences the pituitary (Ohlsson et al. 2009). However, the target sites of IGF-1 for regulating $\mathrm{GH}$-release remain unclear and might either be located in the hypothalamus and/ or the pituitary. Recently, a cell-specific knockout mouse in which the IGF-1 receptor (IGF-1R) was ablated from the somatotroph, the so called somatotroph IGF-1 receptor knockout (SIGFRKO) mouse, has been generated (Romero et al. 2010). The phenotype of the SIGFRKO mouse includes increased GH expression and secretion as well as increased serum IGF-1 levels (Romero et al. 2010). Feedback mechanisms in the hypothalamus resulted in decreased GHRH and increased GHIH mRNA levels (Romero et al. 2010). Furthermore, decreased growth hormone releasing hormone receptor (GHRH-R) expression was observed in the anterior pituitary (Romero et al. 2010). However, these changes were not able to reduce GH secretion in the SIGFRKO mouse indicating a role of IGF-1R signalling in the pituitary in addition to the hypothalamus in regulating GH secretion (Romero et al. 2010). IGF-1 influences glucose metabolism directly, e.g. by inducing insulin-like effects on glucose-uptake in tissues expressing IGF-1-receptors, but also by suppressing the GHrelease from the pituitary. GH is known to have diabetogenic effects (Yakar et al. 2004) by decreasing insulin-sensitivity in skeletal muscle, liver and fat. Consequently, LID mice show an impaired insulin-sensitivity. At the same time, those mice are protected against the increase in body fat mass that occurs in older age (Sjogren et al. 2001; Tang et al. 2005). This might be explained by elevated GH-levels in these mice (Ohlsson et al. 2009) as decreased $\mathrm{GH}$ secretion in both rodents and humans has been proposed to contribute to age-related obesity (Sonntag et al. 1980; Rudman et al. 1990).

The inactivation of IGF-1 or its receptor during early development reduces brain size including a reduction of the granule cell layer in the dentate gyrus and the number of oligodendrocytes and myelinated axons (Beck et al. 1995; Holzenberger et al. 2001; VicarioAbejon et al. 2003) demonstrating the importance of IGF-1 signalling during brain development. LID mice show a milder phenotype with reduced exploratory activity (Svensson et al. 2005; Bohlooly et al. 2001), as well as impaired spatial learning and memory, suggesting that liver-derived IGF-1 enhances brain functions (Svensson et al. 2006). Circulating IGF-1 is essential for mediating exercise induced effects on the adult brain by promoting the numbers of newly generated neurons in the adult hippocampus, brain vessel growth, spatial learning and reducing anxiety (Trejo, Carro, and Torres-Aleman 2001; Trejo, Llorens-Martin, and Torres-Aleman 2008; Lopez-Lopez, LeRoith, and Torres-Aleman 2004). Additionally, liver-derived IGF-1 might enhance the clearance of brain amyloid- $\beta$ (A $\beta$ ), whose aggregation is one of the hallmarks of $\mathrm{AD}$ (see 5.1).

\subsection{IGF-binding proteins}

Only a small amount of IGF-1 ( 1 \%) circulates "free" within the blood. The remaining $99 \%$ are bound to IGF-binding proteins (IGFBPs). IGFBPs are a family of at least six proteins (IGFBP-1 to IGFBP-6), which bind IGF-1 with high affinities that are equal to or greater than 
those of the IGF-1 receptor (Duan and Xu 2005). Additionally, there are several proteins with lower IGF-1 binding affinity, called IGFBP-related peptides (IGFBP-rPs), which have significant structural homologies with the amino(N)-terminal region of high-affinity IGFBPs (Rechler 1993; Kelley et al. 1996; Rajaram, Baylink, and Mohan 1997; Kim et al. 1997; Poretsky et al. 1999; Baxter 2000). So far, the functions of the IGFBP-rPs, also referred to as IGFBP- 7 to 10, are not known (Mohan and Baylink 2002). Approximately $75-80 \%$ of IGF is present as a $150 \mathrm{kDa}$ complex, which consists of IGF-1/IGF-2 plus IGFBP-3 (70-75 \%) or IGFPB-5 (5-10 \%) and an acid-labile subunit (ALS) (Baxter, Meka, and Firth 2002). ALS is mainly produced in the liver (Baxter 1988; Baxter and Martin 1989; Baxter, Martin, and Beniac 1989) and its gene disruption leads to a reduction of circulating IGFs of $80 \%$ (Boisclair et al. 2001). The ternary complex of IGF-1 or -2/ IGFBP-3 or -5/ ALS extends the half-life of IGFs to 15-20 h, compared to a half-life of 20-30 min for free IGF-1 in circulation (Guler, Zapf, and Froesch 1987) suggesting a reservoir function of this complex, which cannot cross the vascular endothelial barrier (Rajaram, Baylink, and Mohan 1997; Baxter 2000). 20-25 \% of the IGFs bind to IGFBP-1,2,-4 or -6 to form a complex, which is able to cross vascular endothelium (Baxter 2000; Rajaram, Baylink, and Mohan 1997). Thus, the endocrine actions of IGF-1 in serum are regulated by the IGFBPs determining how much IGF is bio-available to the local tissues.

Furthermore, IGFBPs are located in the extracellular matrix or on the cell surface where they either inhibit (mainly IGFBP-4 and -6) or potentiate (mainly IGFBP-3 and -5) IGF-1 binding to its receptors (Rajaram, Baylink, and Mohan 1997; Mohan et al. 1995; Qin et al. 1998; Jones and Clemmons 1995; Firth and Baxter 2002; Rechler and Clemmons 1998). Functions of the IGFBPs might vary indicated by the inhibiting or potentiating effect of IGFBP-1, $-2,-3$ and -5 on IGF-1 action depending on the experimental conditions (Yin, $\mathrm{Xu}$, and Duan 2004).

The actions of IGFBPs are, in turn, modulated by IGFBP proteases that are further dependent on activators and inhibitors (Mohan et al. 2002). Those IGFBP proteases are able to cleave IGFBPs, thereby reducing their affinity for IGF-1. Some of them are relatively specific for a given IGFBP. For example, pregnancy-associated plasma protein-A (PAPP-A), which is produced by a variety of cell types, cleaves specifically IGFBP-4 (Lawrence et al. 1999; Byun et al. 2001; Conover et al. 2001), whereas complement C1s (Busby et al. 2000) and a disintigrin and metalloprotease-like (ADAM)-9 (Mohan et al. 2002) were identified to be relatively specific for IGFBP-5. Additionally, a number of other serum proteases were shown to be capable of cleaving IGFBPs, e.g. plasmin, cathepsin D and prostate specific antigen (Conover 1995; Fowlkes et al. 1995; Rajah et al. 1995; Rajaram, Baylink, and Mohan 1997; Maile and Holly 1999). Therefore, the binding affinity and hence the bio-availability of IGF-1 is regulated via the degradation of IGFBPs through the IGFBP protease system.

IGFBPs also have IGF independent functions, for example IGFBP-2 and -3 can induce direct cellular effects (Firth and Baxter 2002; Oh et al. 1993; Yamanaka et al. 1999; Schutt et al. 2004) and it has been shown that IGFBP-3 at least partially mediates these effects by binding to the cell surface, possibly to specific receptors (Mohseni-Zadeh and Binoux 1997; Rechler and Clemmons 1998). IGFBP-2, -3 and -5 contain sequences for nuclear localisation (Schutt et al. 2004; Radulescu 1994; Schedlich et al. 1998; Hoeflich et al. 2004) and might as well influence gene expression.

\subsection{The insulin- and insulin-like growth factor-1 signalling pathway}

Insulin and IGF-1 receptors are receptor tyrosine kinases. Receptor tyrosine kinases contain a membrane-bound domain with tyrosine kinase activity which phosphorylates tyrosineresidues of downstream signalling proteins. Typical members of the receptor tyrosine kinase 
family are the epidermal growth factor receptor (EGFR), the nerve growth factor receptor (NGFR) and the insulin receptor (IR). The IR was discovered in 1974 and its tyrosine kinase was found in 1982 (Kasuga, Karlsson, and Kahn 1982; Kasuga et al. 1982). Later, in addition to the IR, the insulin-like growth factor-1 receptor (IGF-1R) was discovered as a tyrosine kinase activity containing receptor (Jacobs et al. 1983; Rubin, Shia, and Pilch 1983).

The IR and IGF-1R are heterotetrameric structures. The different subunits are linked by disulfide bonds. The a-subunits are exclusively localised extracellular (Van Obberghen et al. 1981; Ullrich et al. 1986). The $\beta$-subunits consist of a short extracellular part, a transmembrane domain and an intracellular part with ATP-binding motifs, autophosphorylation sites and tyrosine-specific protein kinase activity, which is activated after binding of insulin or IGF-1 to their receptors (Chou et al. 1987).

The insulin receptor gene consists of 22 exons and 21 introns (Seino et al. 1989). Alternative splicing of exon 11, which codes for 12 amino acids, causes two different isoforms: A, which lacks the 12 amino acids, and B. This alternative splicing does not exist for the IGF-1 receptor, because this receptor contains no equivalent to exon 11 of the IR. The A- and Bisoforms both bind to insulin with similar affinity (McClain 1991). The A-isoform has a higher affinity to IGF-1 (Yamaguchi et al. 1991) and IGF-2 (Frasca et al. 1999) compared to the B-isoform. The A-isoform is expressed in hematopoietic cells, fetal tissue and the adult nervous system. The B-isoform of the IR is mainly present in liver, adipose tissue and muscle (Seino and Bell 1989; Moller et al. 1989; Goldstein and Kahn 1989; Mosthaf et al. 1990). The selective binding of insulin or IGF-1 is also dependent on the assembly of the receptors (Pandini et al. 2002). The hybrid of IGF-1 receptor and the A-isoform of the IR binds IGF-1, IGF-2 and insulin with similar affinity. The hybrid of the IGF-1R and the Bisoform of the IR only binds IGF-1 (Louvi, Accili, and Efstratiadis 1997).

\subsubsection{Insulin receptor substrates}

The binding of IGF-1 or IGF-2 to the IGF-1R causes a conformational change of the receptor, which induces autophosphorylation. This leads to the recruitment of insulin receptor substrates (IRS) to the autophosphorylated receptor tyrosine kinase, which in turn phosphorylates the tyrosine residues of the IRS proteins (Figure 2). The IRS protein family consists at least of four proteins, IRS-1 to IRS-4 (Sun et al. 1991; Lavan et al. 1997; Lavan, Lane, and Lienhard 1997).

The IRS proteins show different expression patterns. IRS-1 and -2 are ubiquitously expressed, but IRS-3 is only present in rodent adipose tissue. IRS-4 mainly occurs in thymus, hypothalamus, kidney and heart. All IRS proteins share the same structural characteristics and have similar functions (Giovannone et al. 2000; Schubert et al. 2003).

The four IRS family members contain an N-terminal pleckstrin homology (PH) domain, a phosphotyrosine-binding (PTB) domain and a C-terminal tail containing multiple tyrosine phosphorylation sites. The phosphotyrosine motifes of the IRS proteins are binding sites for Src homology(SH)2 domain-containing proteins (Yenush and White 1997). The PH domain binds to lipids and with high affinity to phosphoinositides (Fruman, Rameh, and Cantley 1999). The PTB domain of IRS binds to phosphotyrosine residues of other proteins including the IR and IGF-1R. In more detail, the PTB domain binds to the phosphorylated NPXP motif at the juxtamembrane domain of the receptor after binding of insulin or IGF-1. Following binding to this motif, the IRS proteins are tyrosinephosphorylated (Cheatham and Kahn 1995; White 2002). 
Only IRS-2 contains a domain which binds to the phosphorylated kinase regulatory loop of the $\beta$-subunit of the IR. This domain is called the KLRB domain (Sawka-Verhelle et al. 1997; Sawka-Verhelle et al. 1996). However, the physiological function of the KLRB domain of IRS-2 remains unclear.

Insulin induces tyrosine and serine phosphorylation of IRS-1 (Gual, Le Marchand-Brustel, and Tanti 2005). These phosphorylations lead to specific regulation of downstream signalling. The phosphorylation of serine residues of IRS-1 contribute to positive or negative regulation of IRS-1 action (Weigert et al. 2005; Weigert et al. 2008). Important for this regulation are the particular phosphorylation sites (Herschkovitz et al. 2007) as well as the timing of phosphorylation (Weigert et al. 2005; Weigert et al. 2008). Currently, the serine phosphorylation sites with positive effect on IRS-1 action are regarded to be phosphorylated at first to support IRS-1 activity protecting from phosphorylation at residues with inhibitory effect (Weigert et al. 2005; Weigert et al. 2008; Gual, Le Marchand-Brustel, and Tanti 2005; Luo et al. 2007). In addition, serine phosphorylation with activating effect might prevent the association of IRS-1 with tyrosine phosphatases (Luo et al. 2005). The serine residues with inhibitory effect are located near the PTB domain. These residues are phosphorylated later than the residues with positive effect upon insulin stimulation or other signals. The phosphorylation of serine sites near the PTB domain causes disruption of the binding between IRS-1 and the IR followed by degradation of IRS-1. The phosphorylation of inhibitory serine residues in the C-terminus of IRS-1 disturb their interaction with the phosphatidylinositide (PI)3-kinase (Figure 2) (Gual, Le Marchand-Brustel, and Tanti 2005; Boura-Halfon and Zick 2009). Serine sites with inhibitory effect are phosphorylated by serine kinases like the mammalian target of rapamycin (mTor), PKCzeta and p70S6 (S6K) kinase (Boura-Halfon and Zick 2009; Herschkovitz et al. 2007; Gual et al. 2003). Insulin and IGF-1 resistance might be induced via kinases like c-Jun N-terminal kinase (JNK), mTor/S6K, inhibotory-кB kinase $\beta$ (IKK $\beta$ ), SIK-2 and extracellular signal regulated kinases (ERK) promoting the phosphorylation of the inhibitory sites of the IRS proteins (BouraHalfon and Zick 2009; Herschkovitz et al. 2007). The IRS-2 serine phosphorylation sites are still under investigation. It is known that JNK phosphorylates Thr348 of IRS-2 which is located near the PTB domain (Solinas et al. 2006) and might cause disruption of the binding between IRS-2 and the receptor. Furthermore, JNK phosphorylates Ser488 of IRS-2 promoting the phosphorylation at Ser484 by glycogen synthase kinase (GSK)-3 $\beta$ and thereby inhibiting the signalling pathway (Sharfi and Eldar-Finkelman 2008).

\subsubsection{PI3K signalling}

The mammalian phosphatidylinositide(PI)3-kinases are subdivided into three classes, class I-III. Class I is further divided into Ia and Ib (Vanhaesebroeck et al. 2005). These classes catalyse the phosphorylation of the 3'hydroxyl position of phosphatidyl-myo-inositol lipids. The PI3K of the insulin and IGF-1 signalling pathway belongs to the class Ia kinases (Fruman, Meyers, and Cantley 1998). These kinases display a heterodimeric structure containing a catalytic subunit of $110 \mathrm{kDa}$. This subunit is non-covalently associated with a $50-, 55-$ or $85 \mathrm{kDa}$ regulatory subunit. Following activation of the insulin receptor and IRS binding, the PI3K is recruited to the membrane via the p85 regulatory subunit. Other recruited factors are the growth factor receptor binding protein (GRB)-2 and the $\mathrm{SH} 2$ Phosphatase(SHP)2 (Figure 2).

The activated PI3K, in turn, phosphorylates phosphatidylinositide-diphosphate $\left(\mathrm{PI}_{4,5} \mathrm{P}\right)$ to produce phosphatidylinositide-triphosphate $\left(\mathrm{PI}_{3,4,5} \mathrm{P}\right)$. This event is reversible by PTEN (the 
phosphatase and tensin homolog deleted on chromosome ten). The generation of $\mathrm{PI}_{3,4,5} \mathrm{P}$ causes activation of the downstream signalling proteins like phosphoinositide-dependent protein kinase (PDK) and protein kinase $\mathrm{B}(\mathrm{PKB}, \mathrm{AKT})$. PDK is present in two isoforms, PDK-1 and PDK-2. PDK-1 phosphorylates AKT at Thr308, which partially activates AKT. To completely activate AKT, phosphorylation of Ser473 is necessary (Alessi et al. 1996; Lawlor and Alessi 2001; Stokoe et al. 1997). AKT is a serine/threonine kinase with a size of $57 \mathrm{kDa}$. It contains a PH domain and there are three isoformes, AKT-1, AKT-2 and AKT-3. These isoforms display a conserved domain structure: a kinase domain, a PH-domain at the $\mathrm{N}$ - as well as a regulatory subunit at the C-terminus (Hresko, Murata, and Mueckler 2003). AKT phosphorylates tuberin 2 (TSC-2). TSC-1 and -2 form a heterodimer with GTPase activity that inhibits the GTPase RHEB (RAS homolog enriched in brain). The phosphorylation via AKT causes the accumulation of the RHEB-GTP complex which activates mTOR (Astrinidis and Henske 2005; Hay and Sonenberg 2004). Furthermore, S6K is activated by phosphorylation of PDK-1 and mTOR (Figure 2). The regulation of protein synthesis via IGF-1 occurs through controlling the intrinsic activity and/or binding properties of specific translation initiation and elongation factors called eIFs and eEFs. mTOR phosphorylates 4E$\mathrm{BP}$ (4E binding protein). This causes the release of eIF4E (eukaryotic initiation factor $4 \mathrm{E}$ ) to form an active complex, which promotes translation initiation and also activation of S6K. S6K phosphorylates the eEF2 (eukaryotic elongation factor 2) kinase which releases eEF2 and initiates elongation (Figure 2) (Nojima et al. 2003; Oshiro et al. 2004).

Other proteins, which are regulated via IR and IGF-1R signalling, are the glycogen synthase kinase(GSK)-3 $\beta$, a major tau kinase, and BAD (Bcl-2/Bcl-X-associated death promoter), a proapoptotic factor. These proteins are inactivated via the IR/IGF-1R signalling cascade (Song, Ouyang, and Bao 2005). BAD interacts with the apoptosis suppressors Bcl-2 and more intense with Bcl- $X_{\mathrm{L}}$ (Yang et al. 1995). BAD directly binds to Bcl- $\mathrm{X}_{\mathrm{L}}$ with its $\mathrm{BH} 3$ homology domain (Zha et al. 1997). This interaction is regulated by the phosphorylation state of BAD. Therefore, the IGF-1R signalling is a potent inhibitor of neuronal apoptosis (Schubert et al. 2003).

\subsubsection{Forkhead box 0 transcription factor}

AKT phosphorylates the Forkhead box O transcription factors (FoxOs). This induces the binding to 14-3-3 and nuclear exclusion of FoxOs and thereby inactivation of FoxOmediated transcription. FoxOs regulate transcription of genes, which are involved in apoptosis, metabolism, growth, ageing and development (Partridge and Bruning 2008).

The mammalian FoxO protein family consists of 4 members: FoxO1, FoxO3a, FoxO4 and FoxO6. These transcription factors contain a conserved DNA binding domain, the forkhead domain (FKHR) (Clark et al. 1993). FoxO1 and FoxO3a are ubiquitously expressed, whereas FoxO6 is exclusively found in the brain, and $\mathrm{FoxO} 4$ has yet not been detected in the brain (Furuyama et al. 2000; Jacobs et al. 2003). The expression pattern of the different FoxOs in the adult mouse brain is distinct. FoxO1 is predominantly expressed in the striatum, dentate gyrus and ventral hippocampus and FoxO3a in the cortex, cerebellum and hippocampus. FoxO6 is expressed in amygdala, hippocampus and cingulite cortex (Hoekman et al. 2006).

The FoxO transription factors are regulated by post-translational modifications. One major modification is the phosphorylation of the FoxOs. FoxO1 is phosphorylated by AKT at Thr24, Ser256 and Ser319 (Biggs et al. 1999; Brunet et al. 1999; Kops et al. 1999; Rena et al. 1999; Tang et al. 1999). Phosphorylation triggers binding to 14-3-3 and subsequently 
translocation out of the nucleus terminating FoxO mediated transcription (Figure 2) (Brunet et al. 1999). Additionally, FoxOs are phosphorylated by other kinases depending on the stimulus (Huang and Tindall 2007). Furthermore, FoxOs are regulated by ubiquitylation. Ubiquitylation is dependent on phosphorylation of Ser256 of FoxO1 via AKT (Huang et al. 2005). FoxO1 and FoxO3a need to be polyubiquitylated for degradation. In contrast, FoxO4 requires monoubiquitylation to be degraded (van der Horst et al. 2006). Another regulatory mechanism for FoxO transcription is acetylation. CBP and p300 with their associated proteins, for example CBP- and p300-associated factor (PCAF), display intrinsic histone acetyl-transferase activity. These proteins promote transcription via histone acetylation and they directly regulate transcription via acetylation of particular transcription factors ( $\mathrm{Li}$ et al. 2002). It has been shown that CBP acetylates FoxO transcription factors and inhibits their action (Daitoku et al. 2004). Silent information regulator 1 (SIRT1) is a nicotinamide adenine dinucleotide(NAD)-dependent histone deacetylase, which forms a complex with acetylated FoxOs upon stress stimuli and deacetylates the transcription factors (Brunet et al. 2004; Kitamura et al. 2005) to regulate FoxO mediated transcription.

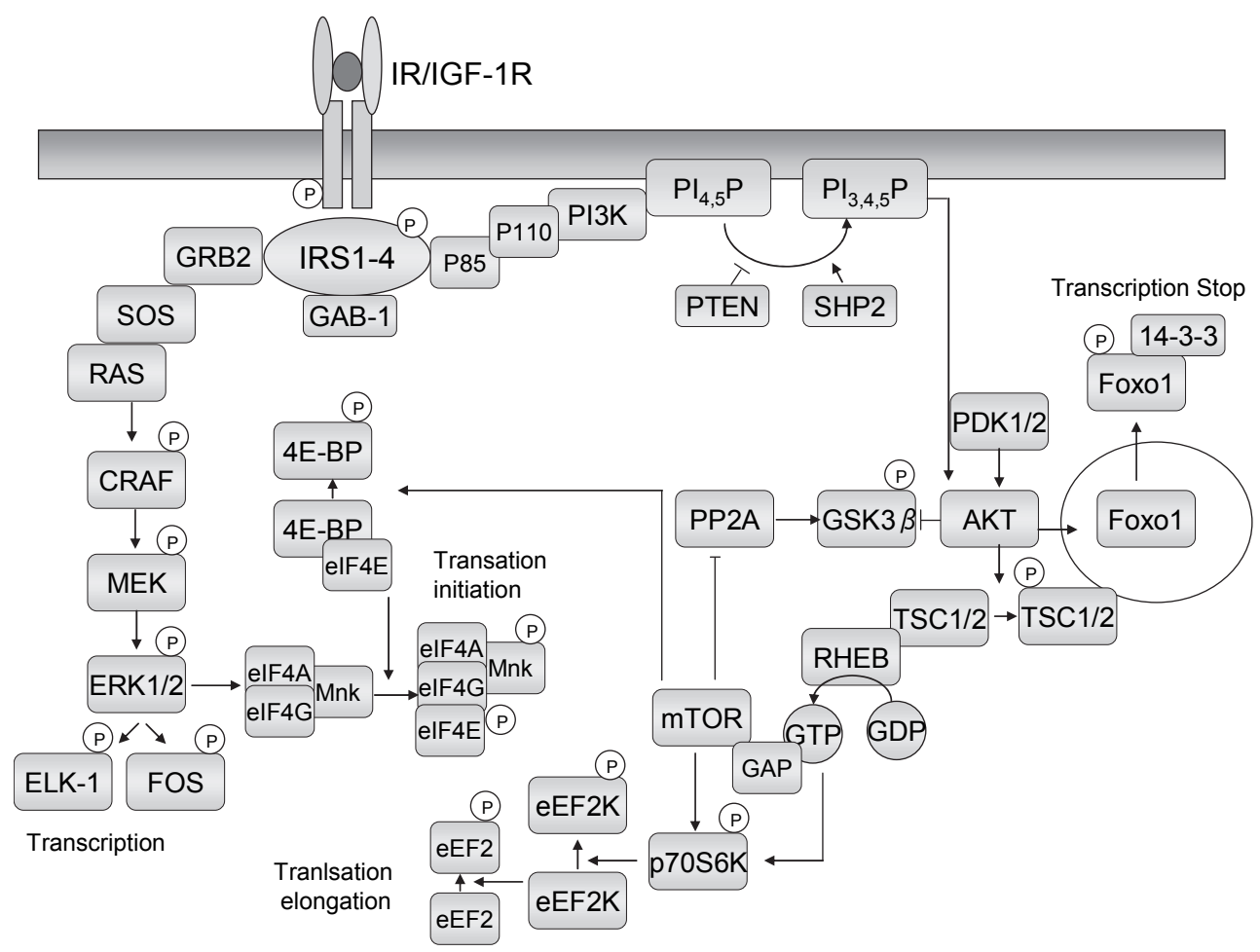

Fig. 2. IR/IGF-R signalling

The binding of Insulin or IGF-1 to the IR/IGF-1R causes autophosphorylation and activation of the receptor. Insulin receptor substrates (1-4) are recruited to the activated receptor and IRS phosphorylation results in activation of the MAP kinase (MAPK, mitogen activated protein kinase) and phosphatidylinositide(PI)3-kinase (PI3K) pathway. 


\section{IGF-1 signalling in the brain}

\subsection{IGF-1's transport across the blood brain barrier}

In the brain, present IGFs arise either by de novo synthesis or by transport from the blood into the brain. So far, the exact mechanisms of how IGFs cross the blood-brain barrier (BBB) are not fully understood. Early in vitro studies by Duffy and colleagues on isolated human brain capillaries showed that the affinity of IGF-2 to isolated human brain capillaries was approximately twofold higher than the affinity of IGF-1 binding and binding of both IGFs was nonsaturable over the range of 1 to $200 \mathrm{ng} / \mathrm{ml}$ IGF suggesting that there is a very efficient endocytosis mechanism (Duffy, Pardridge, and Rosenfeld 1988). Insulin displaced binding of IGF-1 (50\% inhibited by $2 \mu \mathrm{g} / \mathrm{ml}$ Insulin) and IGF-2 ( $50 \%$ inhibited by $0,5 \mu \mathrm{g} / \mathrm{ml}$ Insulin). Furthermore, binding was largely inhibited by adding human serum, which was assumed to be due to the presence of IGFBPs (Duffy, Pardridge, and Rosenfeld 1988). Subsequent studies suggested that there might be a high capacity transport system across the BBB, which is influenced by the IGFBPs (Pan and Kastin 2000). Tores-Aleman and coworkers found that via the choroid plexus epithelium, circulating IGF-1 is transported into the CSF through a mechanism involving the multicargo protein tranporter low-density lipoprotein receptor related protein 2 (LRP2), and concluded that increasing levels of IGF-1 in the CSF, as a result of increasing IGF-1 levels in the serum, might be explained via this transport mechanism (Carro et al. 2000; Carro et al. 2005). LRP1, another membrane cargotransporter, was suggested as targeting platform for the circulating IGF-1/IGFBP-3/ALScomplex (Nishijima et al. 2010). LRP1 is abundantly expressed in brain endothelium and seems to be a cellular receptor for IGFBP-3 (Huang et al. 2003). Recently, it has been demonstrated that neuronal activity increases the permeability of the BBB for IGF-1 through neurovascular coupling (Nishijima et al. 2010). Therefore, serum IGF-1 might influence brain processes like synaptic plasticity and cognition. Furthermore, neurovascular coupling was proposed to locally change cerebral blood flow leading to activation of matrix metalloprotease 9 (MMP9) through diverse mediators (arachdonic acid derivates, ATP, etc.). MMP9 is an IGFBP-3 cleaving protease, which is released in response to neuronal activity (Michaluk and Kaczmarek 2007) and might link neuronal activation to the transport of serum IGF-1 via a LRP1 depending mechanism across the BBB (Nishijima et al. 2010). Hence, neurovascular coupling might result in neurotrophic coupling explaining the neuroprotective effects of physical as well as mental exercise and active social life on brain function (Carro et al. 2000; Fratiglioni, Paillard-Borg, and Winblad 2004).

\subsection{Brain IGF receptors}

IGF-1 and to less extend IGF-2 bind and therefore activate the type 1 IGF-receptor (IGF-1R) (Rubin and Baserga 1995; White and Kahn 1994; LeRoith 2000). Several IGF-1R subtypes have been reported, for example the hybrid IGF-1Rs, which are hybrid dimers of the insulinreceptor (IR) and the IGF-1R (see 2.3) binding insulin as well as IGFs with similar affinity (Soos and Siddle 1989; Soos et al. 1990; Siddle et al. 1994; Moxham, Duronio, and Jacobs 1989; Pandini et al. 2002). The physiological significance of these receptor subtypes is still unclear (Russo et al. 2005).

Additionally, there is a type 2 IGF-receptor (IGF-2R) with a short cytoplasmic domain lacking a tyrosine kinase harbouring a higher affinity for IGF-2 than the IGF-1R (Sakano et al. 1991; Oh et al. 1991; Dore, Kar, and Quirion 1997; Braulke 1999; Kiess et al. 1994). This IGF-2R is a cation-independent mannose-6 phosphate (M6P) receptor binding not only IGF- 
2 but M6P-containing ligands. This receptor functions in the mediation of endocytosis and lysosomal enzyme trafficking and regulation of apoptotic/ mitogenic effects (Morgan et al. 1987; von Figura and Hasilik 1986; Ghahary et al. 2000). Recent studies have demonstrated that IGF-2 influences memory enhancement via the IGF-2R suggesting that the IGF-2R might transmit some intracellular signalling (Chen et al. 2011).

\subsection{IGF receptor expression in the brain}

IGF-1R mRNA is widely expressed in the developing CNS and persists at high levels in the mature brain especially in neuron-rich regions such as the olfactory bulb, the granule cell layer of the dentate gyrus and cerebellar cortex (Rotwein et al. 1988; Bondy et al. 1990; Bondy and Lee 1993; Werther et al. 1990). Glia cells have a lower IGF-1R expression than neurons and therefore regions mainly containing those cells, like white matter zones, show low IGF-1R mRNA levels (Bondy and Lee 1993). Some neurons, which are still in the process of developing, express increasing IGF-1R mRNA levels postnatal until they have reached maturity, for example Purkinje cells (Bondy et al. 1992). In the adult brain, high expression levels of IGF-1R mRNA are also found in the choroid plexus, meninges and vascular sheaths (Bondy et al. 1992; Bohannon et al. 1988; Werther et al. 1989; Matsuo et al. 1989; Marks, Porte, and Baskin 1991).

The IGF-2R is abundantly expressed in the CNS, especially in the pyramidal cell layers of the hippocampus, the granule cell layer of the dentate gyrus, olfactory bulbus, choroid plexus as well as in the microvasculature, retina, pituitary, brainstem and spinal cord (Hawkes and Kar 2004; Couce, Weatherington, and McGinty 1992; Wilczak et al. 2000; Valentino, Ocrant, and Rosenfeld 1990).

In addition to the IGF-1R and the IGF-2R, IR and IGF-1R hybrids are expressed in the brain, through which IGFs and insulin induce intracellular signalling. IRs are mainly expressed in regions that are linked to olfaction, appetite and autonomic functions, such as the olfactory bulb, limbic system and hypothalamus (Werther et al. 1987; Unger, Livingston, and Moss 1991) and seem to play a key-role in controlling feeding, body weight and reproduction (Bruning et al. 2000). Furthermore, IR expression is also present in remarkable concentration in the choroid plexus, circumventricular organs and brain microvessels (van Houten and Posner 1979, 1981; Werther et al. 1987) suggesting the IRs might contribute to the transport of insulin and possibly IGF-1 across the BBB.

\section{IGF-1 action in the developing brain}

\subsection{Brain growth and myelination}

Different mouse models indicated the essential actions of IGF-1 signalling for normal brain development. Homozygous IGF-1 knockout mice (IGF-1/-), homozygous IGF-2 knockout mice (IGF-2-/-) as well as doubly deficient mutants are viable but have small brains (Beck et al. 1995; Liu et al. 1993). The majority of homozygous IGF-1/- mice die perinatally and those which survive $(<5 \%)$ demonstrate severe growth retardation with reduction in brain weight of $38 \%$ distributed evenly over all major brain areas (Beck et al. 1995). However, certain cell-types and brain-regions were especially affected by the IGF-1 gene disruption such as white matter, striatum and hippocampus (Beck et al. 1995). The reduction of white matter was due to a net loss of axons and an additional shift from myelinated to unmyelintated fibres indicating the role of IGF-1 in axonal growth and/or maturation and its effect on the amount of oligodendrocytes and axon-myelination (Beck et al. 1995). These findings are in line with many in vitro studies, which demonstrated a stimulating effect of 
IGF-1 on oligodendrocyte survival, development and proliferation (McMorris et al. 1986; McMorris and Dubois-Dalcq 1988; Mozell and McMorris 1991). In addition, formation of hippocampal granule cells and striatal parvalbumin-containing neurons was reduced in IGF-1/- mice and therefore seems to require IGF-1 (Beck et al. 1995). Most dentate granule neurons as well as the myelination of axons are generated during postnatal development (Altman and Bayer 1990, 1990; Morell et al. 1972; Matthieu, Widmer, and Herschkowitz 1973) suggesting that IGF-1 plays a more important role during late embryonic and postnatal development. Intrauterine development was analysed in detail in single and combined homozygous knockout mice for IGF-1 and IGF-2 suggesting that before E13.5 the IGF-1R exclusively mediates IGF-2 actions and later, with increasing IGF-1 expression, the IGF-1R interacts with both IGFs (Baker et al. 1993). IGF-2 was found to be upregultaed in IGF-1 $\%$ mice suggesting that IGF-2 may partially compensate for the loss of IGF-1 expression and function (Ye et al. 2002).

Homozygous IGF-1R knockout mice (IGF-1R-/-) die at birth and have smaller brains (Liu et al. 1993). A similar growth retardation of the CNS was observed in transgenic mice overexpressing human IGFBP-1 (hIGFBP-1) suggesting reduced IGF-1 action via IGF-1Rs (D'Ercole et al. 1994). Conversely, transgenic mice overexpressing human IGF-1 (hIGF-1) show increased brain growth and myelination (Carson et al. 1993; Ye, Carson, and D'Ercole 1995). In both mouse models, the transgenic hIGFBP-1 and hIGF-1 mouse, the cerebral cortex, hippocampus and diencephalon were the most affected brain regions (Ye, Carson, and D'Ercole 1995). Myelination was increased in hIGF-1 and reduced in hIGFBP-1 transgenic mice as well as the number of oligodendrocytes and the expression of myelinspecific proteins, respectively (Ye, Carson, and D'Ercole 1995). During development, the increase of myelin protein expression in the cerebral cortex of hIGF-1 transgenic mice correlates with the hIGF-1 transgene mRNA levels (Ye, Carson, and D'Ercole 1995). In conclusion, IGF-1 plays a crucial role in regulating neuronal growth and differentiation (Werther et al. 1998), but also enhances oligodendrocyte survival and myelination (Beck et al. 1995).

Several studies suggested that transcriptional programs control the development of axons or dendrites including their growth and branching (Jan and Jan 2003; Goldberg 2004; Polleux, Ince-Dunn, and Ghosh 2007). Recently, the role of FoxO-transcription factors, major downstream-targets of IIS (Insulin/IGF-1 signalling pathway), within the developing brain and their action of conducting IGF-1 signalling started to become clearer. FoxO proteins were found to be key-regulators of neuronal polarity in the mammalian brain and to trigger differentiation from immature neurons to post-mitotic neurons with specified axon- and dendrite-formations (de la Torre-Ubieta et al. 2010). In addition, protein kinase Pak1 was identified as direct target of FoxO-transcription factors linking FoxO-dependent transcription in the nucleus to an enzyme that promotes axonal polarity by controlling actin and microtubule dynamics (Edwards et al. 1999; Wittmann, Bokoch, and Waterman-Storer 2004) as well as dendritic spine morphogenesis and synapse differentiation (Hayashi et al. 2004; Hayashi et al. 2007; Nikolic 2008). Apart from Pak1, FoxO knockdown neurons demonstrated a number of downregulated polarity genes, such as Par6, R-Ras, APC and CRMP2 (de la Torre-Ubieta et al. 2010). Additionally, FoxO3a was shown to regulate homeostasis of neuronal stem cells (NSCs) both in vitro and in vivo by controlling a set of genes that determines cell cycle re-entry and optimal oxygen and glucose metabolism (Renault et al. 2009). However, the effect of FoxO3a deficiency in NSCs only became apparent in adult animals, as NSCs were shown to influence learning, memory and mood 
(Zhang et al. 2008). Therefore, NSC homeostasis regulated by FoxO3a might influence the decline of cognitive function and possibly the onset of neurodegenerative diseases (de la Torre-Ubieta et al. 2010).

\subsection{Neuroendocrine regulation}

Embryonic brain IGF-1R and therefore the action of the IGF-1 pathway in the developing brain was found to play a crucial role in determining somatotrophic plasticity and hence postnatal GH and IGF-1 signalling. These observations were made in a brain specific IGF-1R knockout mouse model (bIGF-1RKO-/; bIGF-1RKO ${ }^{+/-}$) by the group of Holzenberger (Kappeler et al. 2008). Whereas homozygous mutants (bIGF-1RKO-/-) showed severe growth retardation and were infertile, heterozygous mutants (bIGF-1RKO $\left.\mathrm{RO}^{+-}\right)$were healthy and had an increased mean lifespan compared to controls (Kappeler et al. 2008). In bIGF-1RKO+/mutants, serum IGF-1 and GH were lowered and pituitaries, like most other organs, were smaller compared to controls (Kappeler et al. 2008). As IGF-1Rs are only diminished in the brain but not in the anterior pituitary in this mouse model, the observed phenotype was proposed to result from alterations in GH-regulatory neurons of the hypothalamus. Hypothalamic GHRH expression was found to be significantly lower, as well as the Pit-1 mRNA levels. bIGF-1RKO ${ }^{+/-}$mice had preserved gonado- and thyrotropic functions but were growth retarded with a body length $5 \%$ shorter than controls and a body weight of about $90 \%$ of controls at the age of 90 days (Kappeler et al. 2008). Interestingly, weight gain with age was slightly higher in adult bIGF-1RKO ${ }^{+/-}$mice than in controls, and female mutants finally reached the same body weight than controls (Kappeler et al. 2008). The gain of weight was most probably due to an enlargement of subcutaneous adipose tissue (AT), as there was less or no increase in visceral AT (Kappeler et al. 2008). In line with GH-deficient mouse models (Berryman et al. 2004; Berryman et al. 2006), the bIGF-1RKO+/- mice showed impaired glucose homeostasis and fat metabolism. Heterozygous inactivation of IGF-1R had no detectable effects on behaviour or other brain functions apart from the somatotrophic deficit. Compared to control littermates, bIGF-1RKO ${ }^{+/-}$mice had a significantly longer mean lifespan. However maximum lifespan was unchanged probably due to increased late-life mortality caused by hyperglycemia and dyslipidemia (Kappeler et al. 2008). Early dietary restriction showed a similar neuroendocrine response as the brain specific IGF-1R knockout (Kappeler et al. 2008), indicating a connection between nutrition, somatotrophic hormones, growth and their determination of lifespan.

Similar observations, in which morbidity in later life was determined during prenatal development, were made in humans. Long-term studies have been conducted on the Dutch famine birth cohort as well as on the Chinese famine cohort. Babies exposed in utero to calory restriction in late or mid gestation were growth retarded and showed impaired glucose tolerance in later life (Ravelli et al. 1998; Painter, Roseboom, and Bleker 2005). However, babies exposed in early gestation were not smaller than controls but demonstrated the most striking consequences of in utero undernutrition, namely a threefold increase in coronary heart disease, hyper-/dyslipidemia and more frequent obesity (Painter, Roseboom, and Bleker 2005; Ravelli et al. 1999; Roseboom, van der Meulen, Osmond, Barker, Ravelli, Schroeder-Tanka et al. 2000; Roseboom, van der Meulen, Osmond, Barker, Ravelli, and Bleker 2000). Interestingly, mortality rates at older (50+) ages are significantly higher in the exposed group, and residual life expectancy at age of 50 was reduced by approximately 3 years (Lindeboom, Portrait, and van den Berg 2010), which is in line with the increased late-life mortality observed in the bIGF-1R + - mice. In the cohort of 
the Chinese famine, fetal and infant exposure to undernutrition also resulted in increased risk for metabolic syndrome (Li et al. 2010; Li et al. 2011; Yang et al. 2008; Luo et al. 2006).

In summary, IGF-1 signalling during early development is defined by the number of brain IGF-1Rs or their sensitivity and determines endocrine as well as metabolic function in later life possibly playing a key-role in pathogenesis of age-associated diseases.

\begin{tabular}{|l|ll|}
\hline \multicolumn{1}{|c|}{$\begin{array}{c}\text { IGF-1 function in the developing } \\
\text { brain }\end{array}$} & IGF-1 function in the adult brain \\
\hline - $\begin{array}{l}\text { growth and differentiation } \\
\text { of neurons } \\
\text { neuronal polarity and } \\
\text { synapse formation } \\
\text { growth of }\end{array}$ & $\begin{array}{l}\text { preservation of neuronal } \\
\text { plasticity, for example in the } \\
\text { olfactory bulb } \\
\text { oligodendrocytes } \\
\text { enhancement of myelination } \\
\text { neuroendocrine regulation of } \\
\text { metabolism }\end{array}$ & $\begin{array}{l}\text { brain vessel growth } \\
\text { spatial learning and other } \\
\text { cognitive functions } \\
\text { neuroprotecetive in ischemic or } \\
\text { traumatic injuries and several } \\
\text { neurological disorders } \\
\text { reduced signalling extends } \\
\text { lifespan }\end{array}$ \\
\hline
\end{tabular}

Table 1. Function of IGF-1 in the brain

\section{IGF-1 in Alzheimer's disease}

Alzheimer's disease (AD) is a chronic and progressiv neurodegenerative disease and the most common form of dementia leading to the loss of cognitive abilities and finally to death (Citron 2002; Cole et al. 2007).

AD was first described by Alois Alzheimer, a German physician, in 1906 (Alzheimer et al. 1995). The disease is characterised by $\beta$-amyloid accumulation, formation of extracellular amyloid plaques as well as neurofibrillary tangles. The $\beta$-amyloid plaques mainly contain aggregated amyloid- $\beta$ (A $\beta$ ) peptides (Masters et al. 1985). In contrast, the main components of neurofibrillary tangles are hyperphosphorylated and aggregated tau proteins (Ross et al., 2005). The aggregation of $A \beta$ is thought to be the molecular basis of neurodegenration in $A D$ (Masters et al. 1985).

\subsection{Tau}

The tau proteins consist of a N-terminal projection domain, a short tail sequence and a Cterminal domain with microtubule-binding (MTB) repeats. Six isoforms of tau are known in the human brain. These isoforms emerge from alternative splicing of exons 2, 3 and 10. Exon 2 and 3 encode $\mathrm{N}$-terminal parts of tau and exon 10 codes for an additional MTB repeat. Thus, tau can present three or four MTB repeats (Ballatore, Lee, and Trojanowski 2007; Goedert and Spillantini 2006). Tau is predominantly located in the axons of neurons (Hirokawa et al. 1996) and is to less extend found in dendrites (Ittner et al. 2010). The function of tau is yet not completely understood, but it might influence the stabilisation of microtubules and regulation of axonal transport (Gotz, Ittner, and Kins 2006). Tau is phosporylated at several sites via kinases like glycogen synthase kinase 3 (GSK-3 $\beta$ ), cyclin-dependent kinase 5 (Cdk5), c-Jun N- 
terminal kinase (JNK) and ERK1/2 (Robertson et al. 1993; Hanger et al. 1992; Flaherty et al. 2000; Cho and Johnson 2004; Stoothoff and Johnson 2005). Abnormal high phosphorylation is called "hyperphosphorylation". Hyperphosphorylated tau proteins form so called paired helical filaments, which are characteristic for AD. The degradation of tau is inhibited by phosphorylation at the caspase cleavage sites. It has been shown that the mutation of Ser422, which causes a stable phosphorylation at this site, prevents caspase cleavage (GuillozetBongaarts et al. 2006). GSK-3 $\beta$ is one of the major tau kinases and is inactivated upon phosphorylation of Akt at Ser9 connecting insulin and IGF-1 signalling to tau phosphorylation. The major tau phosphatase in human brain is PP2A (Sontag et al. 1996), which is as well regulated via the IR/IGF-1R pathway suggesting that IR/IGF-1R signalling maintains an equilibrium of phosphorylation and dephosphorylation of tau (Liu et al. 2008; Millward, Zolnierowicz, and Hemmings 1999).

\subsection{Amyloid- $\beta$}

$\mathrm{A} \beta$ is generated by proteolytic cleavage of the amyloid precursor protein (APP), a type-1 integral membrane protein. APP was first described and cloned in 1987 (Kang et al. 1987; Tanzi et al. 1987; Goldgaber et al. 1987; Robakis et al. 1987). The APP gene is located on chromosome 21. Hence, patients with trisomy 21 show a higher risk to develop Alzheimer's disease, because of the additional APP allele. Accordingly, the duplication of the isolated APP gene causes cerebral amyloid angiopathy and amyloidosis suggesting that increased APP expression itself is sufficient to cause Alzheimer-like pathology (Rovelet-Lecrux et al. 2006; Sleegers et al. 2006). Another risk factor for AD are mutations of the APP gene (Vassar 2004; Bertram and Tanzi 2005). APP contains a N-terminal extracellular domain and a shorter C-terminal cytoplasmic domain. Alternative splicing of the APP gene results in different isoforms of APP which are distinguishable by length. APP with 751 and 770 (APP751 and APP770) amino acids mainly occur in non-neuronal tissue. APP695 is mainly localised in neurons (Kang and Muller-Hill 1990). The function of APP and the APP-like proteins (APLP) is not clear yet. These proteins are possibly involved in cell adhesion, apoptosis and axonal transport.

The $\beta$-secretase BACE1 ( $\beta$-site APP-cleaving enzyme) plays an essential role in the production of $\mathrm{A} \beta$. It cleaves $\mathrm{APP}$ at $\mathrm{Asp}^{+1}$ at the N-terminus. The resulting fragments are called APPs $\beta$ and the C-terminal fragment C99. Upon cleavage of C99 by the $\gamma$-secretase, a complex formed by presenilin, nicastrin, Aph- 1 and Pen-2, A $\beta$ peptides $(4 \mathrm{kDa})$ and the APP intracellular domain (AICD) with a size of $6 \mathrm{kDa}$ are generated. $A \beta$-peptides mainly occur in two variants: $A \beta 40$ which ends at residue 40 and $A \beta 42$ ending at residue 42 after cleavage. Predominantly, the $A \beta 42$ is prone to aggregate and forms toxic oligomers. Furthermore, APP is cleaved by the a-secretases ADAM10 (a disintegrin and metalloproteinase-like 10) or TACE (tumour necrosis factor-alpha convertase). This results in the C-terminal fragment C83 and APPsa. The cleavage of APP by a- or $\beta$-secretase is dependent on the competition between both enzymes. In case the $\beta$-secretase cleavage of APP increases, a-secretase processing decreases and vice versa (Vassar et al. 1999; Skovronsky et al. 2000) (Figure 3).

In a healthy brain, there is more production of $A \beta 40(\sim 90 \%)$ than there is of $A \beta 42(\sim 5-10 \%)$ (Walsh and Selkoe 2007). The accumulation of $A \beta 42$ is an important step in the formation of amyloid plaques (Iwatsubo et al. 1994). The A $\beta 42$ :A $\beta 40$ ratio is a diagnostic tool for APP processing and development of AD (Haass and Selkoe 2007).

In addition to age-associated $A \beta 42$ accumulation, mutations in presenilin 1, presenilin 2 and the APP gene lead to familiar early-onset AD (Tabaton and Tamagno 2007; Sherrington et al. 
1996; Tanzi et al. 1992; Schellenberg et al. 1992; Van Broeckhoven et al. 1992; St GeorgeHyslop et al. 1992; Rogaev et al. 1995).

The toxic effect of $A \beta$ is not fully understood yet, but might be induced via generation of ion channels, membrane disruption, oxidative stress, induction of apoptosis and inflammation (Hardy and Selkoe 2002; Nakagawa et al. 2000; Soto 2003; Roberson and Mucke 2006). The $\mathrm{A} \beta$ aggregation process produces different intermediates. $\mathrm{A} \beta$ monomers are soluble and amphipathic with an a-helical conformation and kink regions in water-alcohol mixture (Coles et al. 1998; Crescenzi et al. 2002). A $\beta 40$ displays a random coil structure in aqueous solution (Zhang et al. 2000) and $A \beta 42$ shows $\beta$-sheet structure at physiological conditions (Barrow and Zagorski 1991). A $\beta$ dimers are located intracellular in vivo and show a hydrophobic core (Roher et al. 1996). Small A $\beta$ oligomers are highly cytotoxic compared to mature A $\beta$ fibrils (Dahlgren et al. 2002; McLean et al. 1999; Cleary et al. 2005; Lesne et al. 2006). The so called $A \beta$-derived diffusible ligands (ADDLs) show no fibrillar structure and are neurotoxic in a size of about 17 to $42 \mathrm{kDa}$ (Chromy et al. 2003; Klein, Stine, and Teplow 2004; Lambert et al. 1998). The levels of ADDLs are linked to cognitive impairments in AD (Georganopoulou et al. 2005). A $\beta$ protofibrils are the precursors of $A \beta$ fibrils. These protofibrils are present as rod-like and flexible structures. The dyes Congo red and thioflavin $\mathrm{T}$ bind to the core of the protofibrils, which indicates a high level of $\beta$-sheets (Harper et al. 1999; Arimon et al. 2005; Harper et al. 1997; Kheterpal et al. 2003; Walsh et al. 1997; Williams et al. 2005). A $\beta$ fibrils are insoluble, thermodynamically stable aggregates containing repeats of $\beta$-sheets (Ross and Poirier 2005). They also bind Congo red and thioflavin T (Klunk, Jacob, and Mason 1999; LeVine 1999). The amyloid plaques are extracellular aggregates of insoluble A $\beta$ fibrils (Muller-Hill and Beyreuther 1989). These plaques are surrounded by activated microglia, astrocytes and dystrophic dendrites (Selkoe 2004).

Different clinical studies revealed an association of AD and type 2 diabetes (Janson et al. 2004; Ott et al. 1999; Stewart and Liolitsa 1999). A connection of glucose intolerance, impairment of insulin secretion and the risk to develop AD was recently discovered (Ott et al. 1996; Luchsinger et al. 2004; Ronnemaa et al. 2008). Furthermore, AD patients develop more frequently impaired glucose tolerance and type 2 diabetes (Janson et al. 2004) indicating that IR/IGF-1R signalling might influence AD pathogenesis.

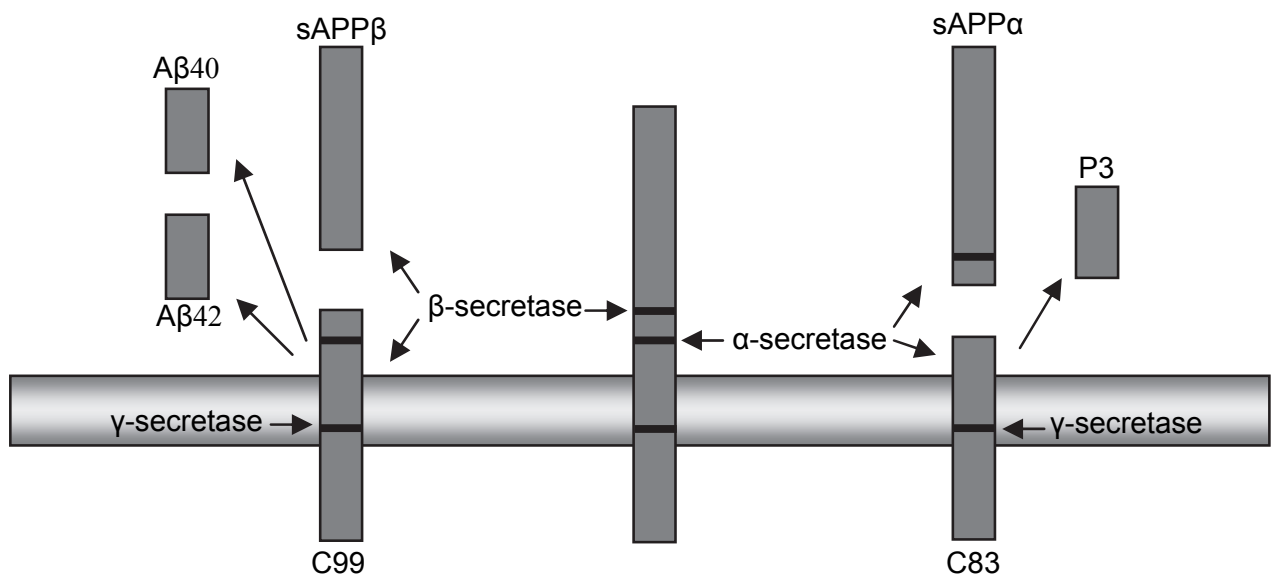

Fig. 3. Processing of amyloid precursor protein (APP). 
APP might be cleaved via the $\alpha-, \beta$ - or $\gamma$-secretase. $\alpha$-secretase cleavage generates a membrane bound C83 fragment and sAPPa. In case C83 is proteolytically cleaved by the $\gamma-$ secretase the $\mathrm{P} 3$ fragment occurs. $\beta$-secreatse processing produces the fragments sAPP $\beta$ and C99. In case of a simultaneous or subsequent cleavage via $\beta$ - and $\gamma$ - secretase the $A \beta 40$ or A $\beta 42$ peptides are released.

\subsection{IR, IGF-1R signalling and Alzheimer's disease}

The IR and IGF-1R signalling pathway is disturbed in the central nervous system (CNS) of AD patients (Frolich et al. 1998; Frolich et al. 1999; Moloney et al. 2010). Analysis of the mRNA level of insulin and the IR showed a decrease of about $80 \%$ in AD patients. Additionally, the expression of the IGF-1R was reduced in AD brains compared to controls (Moloney et al. 2010; Rivera et al. 2005). In contrast, the IGF-1 serum levels of AD patients are increased indicating IGF-1 resistance in AD (Rivera et al. 2005; Vardy et al. 2007). Furthermore, IRS-1 and -2 expression is reduced in AD brains and phosphorylation of IRS-1 at Ser312 and Ser616 is increased, which decreases IRS-1 action characterising AD as "brain type" diabetes (Pilcher 2006). Thus, brains of AD patients are insulin and IGF-1 resistant. Whether these changes are cause or consequence of neurodegeneration is a matter of debate. IGF-1 knockout mice display increase of tau phosphorylation at Ser396 and Ser202 while the tau protein level was not influenced (Cheng et al. 2005). In NIRKO mice, the brain-specific IR knockout mice, tau was hyperphosphorylated at Thr231 (Schubert et al. 2004), whereas IRS-2 knockout mice showed hyperphosphorylation at Ser202 (Schubert et al. 2003). The different phosphorylation patterns of tau in different insulin and IGF-1 resistant mouse models indicate that additional factors may play a role for tau phosphorylation in these models (Freude et al. 2009).

Tg2576 mice express the Swedish mutation of APP (APPsw) and are an established mouse model for analysing amyloid pathology (Vassar et al. 1999; De Strooper 2003; Harada et al. 2006). IRS-2 (IRS-2-/-) or neuron specific IGF-1R knockout (nIGF-1R-/-) in Tg2576 mice protects these mice from premature death and decreases $A \beta$-accumulation (Freude et al. 2009).

BACE-1 and Presenilin-1/-2, which cleave APP and generate neurotoxic A $\beta 42$, are possible targets for $\mathrm{AD}$ treatment since $\beta$-secretase cleavage is the rate limiting step of $\mathrm{A} \beta$ generation. During ageing, the expression of the neurotrophin receptor tyrosine kinase receptor A (TrkA) and the p75 neurotrophin receptor (p75NTR) changes considerably. Whereas TrkA receptor expression decreases, the p75 neurotrophin receptor increases with age. Human neuroblastoma cells SHSY5Y and primary cultured neurons showed a switch from TrkA to p75 ${ }^{\text {NTR }}$ expression after treatment with IGF-1 (Costantini, Scrable, and Puglielli 2006). This increases BACE-1 activity via hydrolysis of sphingomyelin and release of ceramide stabilising BACE-1 (Puglielli 2008; Puglielli et al. 2003). It has been shown that embryonic hippocampal neurons treated with $A \beta 42$ as ligand of p75NTR cause cell death. Neurons, which are deficient in p75NTR and also treated with $A \beta 42$, show less cell death. This may represent the molecular mechanism linking IR and IGF-1R signalling pathway to ageing and neurodegeneration (Sotthibundhu et al. 2008).

In Caenorhabditis elegans the knockdown of DAF-2, the orthologue of mammalian IR and IGF-1R, reduces $A \beta 42$ toxicity (Cohen et al. 2006). This reduced $A \beta 42$ toxicity results from the activity of the downstream transcription factors DAF-16, the orthologue of mammalian FoxO1 and $3 \mathrm{a}$ as well as heat shock transcription factor-1 (HSF-1) (Hsu, Murphy, and Kenyon 2003; Birkenkamp and Coffer 2003; Cohen et al. 2006). The 
detoxification of $\mathrm{A} \beta 42$ by decreased DAF-2 signalling involves two possible mechanisms. First, HSF-1 regulates disaggregation of toxic oligomers followed by degradation of the resulting fragments. Second, DAF-16 regulates the formation of aggregates with high molecular weight and low toxicity, which are built from aggregates with low molecular weight but high toxicity (A $\beta$ hyperaggregation) (Cohen et al. 2006). Recently, $A \beta$ hyperaggregation has been identified as a mechanism of $A \beta$ detoxification in an IGF-1 resistant mouse model of $\mathrm{AD}$ (Cohen et al. 2009).

Several ways of $A \beta$ clearance from the brain have been discovered contributing to $A \beta$ detoxification. A $\beta$ clearance is achieved via transport over the blood brain barrier, enzymatic degradation and phagocytosis by microglia. Recently, several enzymes have been discovered which degrade $A \beta$, e.g. insulin degrading enzyme (IDE), endothelin converting enzyme (ECE), neprilysin, and angiotensin converting enzyme (ACE). The expression of IDE is activated by IR and IGF-1R signalling (Zhao et al. 2004). Transport across the blood brain barrier (BBB) is mediated by distinct receptors. This transport is achieved via binding to the low-density lipoprotein receptor related protein (LRP). The binding of A $\beta$ to LRP occurs directly or in complex with APOE (apolipoprotein E) and/or a2-macroglobulin (a2M). After crossing the $\mathrm{BBB}, \mathrm{A} \beta$ is transported to peripheral tissues for degradation, for example the liver (Tanzi, Moir, and Wagner 2004). It has been proposed that high IGF-1 levels cause degradation or clearance of $\mathrm{A} \beta$. Tg2576 mice present decreased IGF-1 levels compared to wild type mice. The treatment with IGF- 1 yield to increased transport of $A \beta$ from the brain, possibly via the choroid plexus (Carro et al. 2002). Accordingly, the inactivation of the IGF$1 \mathrm{R}$ signalling in the choroid plexus caused AD-like pathology (Carro et al. 2006). In contrast, studies in rats and Tg2576 mice using acute, subchronic and chronic IGF-1 treatment found no changes in tau phosphorylation and A $\beta$ concentrations (Lanz et al. 2008). Possibly, chronic peripheral treatment with IGF-1 causes downregulation of the IGF-1R signalling pathway as it has been shown for a cohort of individuals with high serum IGF-1 level but low IGF-1R signalling (Suh et al. 2008). This might explain the conflicting results of the different studies. AD mouse models with induced insulin resistance via high fat diet displayed an exacerbation of amyloid pathology (Ho et al. 2004).

The different studies dealing with IR/IGF-1R signalling and AD prove a connection between this signalling pathways and $\mathrm{AD}$ pathology. However, the exact molecular mechanisms need to be elucidated.

\section{IGF-1 in the brain and ageing}

IR/IGF-1R signalling is a conserved pathway functioning in development, fertility (Liang et al. 2003; Tatar, Bartke, and Antebi 2003; Broughton et al. 2005), growth (Butler and Le Roith 2001; Ikeya et al. 2002) and metabolic regulation (Saltiel and Kahn 2001). Decreased IR/IGF$1 \mathrm{R}$ signalling causes lifespan extension in model organisms like Drosophila melanogaster, Caenorhabditis elegans and Mus musculus (Clancy et al. 2001; Holzenberger et al. 2003; Tatar et al. 2001).

The life expenctancy of humans has been increased upon environmental amelioration (Wilmoth 2000). However, this is accompanied by an increase of age associated disorders. Therefore, the study of the molecular mechanism of ageing might lead to identification of disease modifying pathways. One of these pathways is the IR/IGF-1R signalling cascade. Studies investigating temporal or spatial restricted changes of the IR/IGF-1R signalling pathway in different model organisms, using the RU486-induced GAL4/UAS (upstream 
activation sequence) in Drosophila, as well as RNAi (RNA interference) incorparation via feeding of bacteria to C. elegans and Cre/loxP system in mice (Roman et al. 2001; Sauer 1998), have been performed.

The CNS is responsible for endocrine release of insulin-like peptides which activate the IR/IGF-1R signalling cascade and subsequently shorten lifespan (Ikeya et al. 2002; Broughton et al. 2005). Confusingly, acute increase of IR/IGF1-R signalling is neuroprotective but reduction of the signalling causes lifespan extension (Bateman and McNeill 2006; Chrysis et al. 2001).

\subsection{IGF-1 signalling in C. elegans}

The impact of IR/IGF-1R-like signalling (IIS) pathway on lifespan was first discovered in C. elegans. IIS in C. elegans is similar to the pathway in mammals (Taguchi and White 2008). It is activated through binding of insulin-like peptides (INS) to DAF-2 (abnormal Dauer formation-2), the IR/IGF-1R in worms (Kenyon et al. 1993). Upon stimulation of DAF-2 an insulin receptor substrate 1 orthologue (IST-1) is recruited to DAF-2 and AGE-1 (AGEing alteration-1), orthologue to human p110. P110, the catalytic subunit of PI3K, promotes the generation of phosphatidylinositide-triphosphate $\left(\mathrm{PI}_{3,4,5} \mathrm{P}\right)$ which then activates AKT kinase family members (Morris, Tissenbaum, and Ruvkun 1996; Kops et al. 1999; Paradis and Ruvkun 1998).

The mutations of DAF-2 and AGE-1 cause lifespan extension in a DAF-16 dependent manner which is a forkhead transcription factor in worms (Kenyon et al. 1993; Lin et al. 1997; Ogg et al. 1997; Morris, Tissenbaum, and Ruvkun 1996) and homologue to the mammalian FoxO1 and FoxO3a.

AGE-1 and DAF-2 mutant worms show enhanced thermotaxis learning behaviour during ageing. This might be due to resistance to neuronal diseases and oxidative stress (Murakami 2007).

The insulin-like peptides (INS) are found throughout the whole body of C. elegans (Pierce et al. 2001; Li, Kennedy, and Ruvkun 2003). Specific sensory neurons regulate lifespan through DAF-16 (Alcedo and Kenyon 2004). The ablation of olfactory neurons causes lifespan extension being only partially dependent on DAF-16 indicating an involvement of other factors. The regulation of INS is not well analysed, but the sensory neurons seem to be the major source of INS for peripheral tissues (Alcedo and Kenyon 2004).

A study using tissue-specific expression of AGE-1 and DAF-16 revealed that wild-type AGE-1 recovers the extended lifespan of AGE-1 mutants. This was shown for wild-type AGE-1 expressed in neurons and the intestine. In addition, wild-type DAF-16 rescues reduced lifespan of DAF-16/AGE-1 double mutants when expressed in neurons or intestine. Moreover, wild-type DAF-16 exerts its full effect when expressed in neurons and the intestine exclusively. However, DAF-16 expression showed only minor effects when expressed in other tissues (Broughton and Partridge 2009; Iser, Gami, and Wolkow 2007).

\subsection{IGF-1 signalling in Drosophila melanogaster}

D. melanogaster posseses endocrine tissues, which are similar to mammals (Toivonen and Partridge 2009). The median neurosecretory cells (mNSCs) of Drosophila are localised in the pars intercerebralis. mNSCs generate three of the seven Drosophila insulin-like peptides (DILPs). These mNSCs are functionally similar to $\beta$-cells of the pancreas which produce 
insulin. These neurosecretory cells show an analogue development to the mammalian anterior pituitary (Wang et al. 2007). The ablation of mNSCs causes lifespan extension, because of the depletion of DILP-2, -3 and -5 (Broughton et al. 2005). In a further study using a dominant-negative form of p53 expressed in the CNS of flies, lifespan extension was induced (Bauer et al. 2005; Slee, O'Connor, and Lu 2004). This correlates with decreased DILP-2 expression and reduced PI3K activity in the periphery (Bauer et al. 2007).

In addition to ablation of mNSCs, mutation of the insulin-like receptor (InR) or of its substrate Chico extends lifespan (Clancy et al. 2001; Tu, Epstein, and Tatar 2002; Tatar et al. 2001). The activation of the InR causes phosphorylation of dFOXO, which is equivalent to nematode DAF-16 and mammalian FoxO1 and FoxO3a (Puig et al. 2003; Junger et al. 2003). $\mathrm{dFOXO}$ activation in the pericerebral fat body has been shown to regulate ageing. This activation of $\mathrm{dFOXO}$ reduces the expression of DLP-2 in mNSCs followed by downregulation of the InR signalling pathway in peripheral fat tissue (Hwangbo et al. 2004)

The JNK signalling pathway in neurons enhances stress resistance and lifespan extension partially via dFOXO (Essers et al. 2004; Wang, Bohmann, and Jasper 2005). Oxidative stress induces JNK signalling and subsequently promotes the nuclear localisation of $\mathrm{dFOXO}$ and induces expression of antioxidant proteins (Huang and Tindall 2007; Kops et al. 2002). Neurons are prone to oxidative stress based on the high production of ROS and low amount of antioxidant proteins (Lin and Beal 2006). Peroxiredoxin abolishes hydroperoxide using thioredoxin as hydrogen donor, which decreases ROS (reactive oxygen species) (Lim et al. 1993). Mammalians express six peroxiredoxins (I-VI). Peroxiredoxin II is solely expressed in the brain (Jin et al. 2005). Jafrac1, the homologue of the human Peroxiredoxin II (hPrxII), is a downstream protein of JNK signalling and target gene of dFOXO in neurons. Jafrac1 reduces reactive oxygen species (ROS) and extends lifespan (Lee et al. 2009) linking decreased IIS to increased clearance of ROS as possible mechanism for lifespan extension.

\subsection{IGF-1 signalling regulates mammalian lifespan}

In mice, it is well known that adult body size is an indicator of GH/IGF-1 actions and negatively correlated to longevity (Rollo 2002; Miller et al. 2002). Furthermore, IGF-1 plasma levels are negatively correlated with median lifespan (Yuan et al. 2009). Up to date, several mouse models of healthy ageing and longevity have been identified and analysed. Most of those long-lived mice have alterations within the IIS, GH or mTOR signalling pathway, indicating their key-role in influencing the process of ageing itself (Broughton and Partridge 2009; Kenyon 2010; Kenyon 2005; Piper et al. 2008; Bluher, Kahn, and Kahn 2003; Kappeler et al. 2008; Selman et al. 2008).

Highest impact on lifespan extension seems to have the ablation of GH signalling, as mutants with impaired GH action demonstrate higher increase of median and maximal lifespan than those with mutations that directly impact IGF-1 signalling (Coschigano et al. 2000; Coschigano et al. 2003; Brown-Borg et al. 1996; Flurkey et al. 2001). Examples for altered GH signalling are the Ames dwarf mice (Prop1def/def), Snell dwarf mice (Pit-1 def/def) and Laron dwarf mice (GHR-/). As the transcription factors Prop1 and Pit-1 are also essential for induction of thyroidea stimulating hormone (TSH) and prolactin, Ames dwarf mice and Snell dwarf mice are not only GH deficient but in addition produce less thyroidea stimulating hormone (TSH) and prolactin. Therefore, it can not be excluded that some of the effects seen in Ames and Snell dwarf mice might arise through deletion of TSH and prolactin. Laron dwarf mice (GHRKO ,GHR-/-) are only resistant to GH signalling, and their longevity phenotype has been reproducible in different laboratories on different genetic 
backgrounds and diets (Coschigano et al. 2003; Bartke and Brown-Borg 2004; Bonkowski et al. 2006).

As described above, GH action is mainly, but not completely, mediated by IGF-1 and circulating levels of IGF-1 are drastically reduced in GH-deficient Ames and Snell dwarf mice as well as in GH-resistant Laron dwarf mice (Brown-Borg et al. 1996; Coschigano et al. 2000; Flurkey et al. 2001). This reduction is primarily due to decreased expression of IGF-1 in the liver, whereas locally derived IGF-1 is, if at all, less affected (Bartke 2011). Normal expression of IGF-1 in the brain, especially in the hippocampus, might explain the maintenance of cognitive function in the long-lived mutants of the GH/IGF-1 system (Kinney et al. 2001). Besides reduced circulating IGF-1, lower insulin levels and enhanced insulin sensitivity are among the most prominent endocrine features shared by Ames dwarf, Snell dwarf and GHRKO mice (Bartke 2006) and have been found to be beneficial for ageing and survival (Bartke 2011). Additionally, increased adiponectin levels, which are associated with improved insulin sensitivity, anti-inflammatory and anti-atherogenic effects, were observed in all three mouse lines (Berryman et al. 2004; Wang et al. 2006). GH-deficient and -resistant mice were also found to have other phenotypic characteristics through which lifespan is thought to be increased, such as resistance to oxidative and other cytotoxic stresses (Bartke et al. 2001; Murakami, Salmon, and Miller 2003), increased activity of antioxidant enzymes (Hauck et al. 2002; Bartke et al. 2001; Romanick, Rakoczy, and BrownBorg 2004), reduced body temperature (Hunter et al. 1999; Hauck et al. 2001) and reduced susceptibility to cancer (Yang et al. 1996; Deitel et al. 2002; Ikeno et al. 2003).

Another model for extended healthy lifespan in mammals is the fat-specific insulin receptor knockout (FIRKO) mouse (Bluher, Kahn, and Kahn 2003). These mutant mice maintain low body fat despite normal food intake, have normal lipid metabolism and demonstrate improved glucose tolerance and insulin sensitivity throughout life (Bluher, Kahn, and Kahn 2003). The underlying mechanisms of this model are not well understood and apart from impaired IR signalling, altered inflammatory state and mitochondrial activity in these animals are discussed.

A remarkable increase of mean and maximal lifespan has been found in female and male mice lacking PAPP-A. PAPP-A is a metalloproteinase that cleaves inhibitory IGFBPs (as described above), thereby increasing local bioavailability of IGF-1 without altering IGF-1 expression (Lawrence et al. 1999). Conversely, deletion of PAPP-A in PAPP-A-/- mice results in reduced local IGF-1 levels, and thus PAPP-A $/-$ mice are born as dwarfs (Conover et al. 2004). In these mutants, extension of lifespan was not associated with impaired glucose or fat metabolism and serum IGF-1, insulin and GH levels were unaltered (Conover and Bale 2007). However, these mice have markedly reduced incidence of spontaneous tumors (Conover and Bale 2007) and were found to be resistant to develop experimentally induced neointimal hyperplasia and atherosclerosis (Harrington, Simari, and Conover 2007; Resch, Simari, and Conover 2006).

As described above, homozygous deletion of the IGF-1R or IGF-1 is lethal or produces severe developmental defects, however extended lifespan was reported in mice with heterozygous deletion of the IGF-1R (IGF-1R 1 -) (Holzenberger et al. 2003). IGF-1R 1 -- mice have upregulated serum IGF-1 levels, which might indicate an endocrine compensatory response to the reduced numbers of IGF-1R, and these mice do not develop dwarfism (Holzenberger et al. 2003). Those mutants have no alterations in energy metabolism, physical activity, fertility and reproduction but display greater resistance to oxidative stress (Holzenberger et al. 2003) probably causing the observed lifespan extension, which is 
predominantly seen in females. As described earlier, the selective reduction of IGF-1 signalling in the brain of bIGF1R $+/$ - mice leads to an increase in median but not maximal lifespan (Kappeler et al. 2008).

The knockout models for IRS-proteins provide evidence that interference with IGF1/insulin signalling downstream of the IGF-1 and insulin receptor influences lifespan in mice. Female IRS-1 knockout (IRS-1/-) mice were reported to be long-lived and resistant to a number of conditions related to neurological and neuromuscular, immune, skin and bone disease (Selman et al. 2008). In these animals, body weight including fat mass was reduced, but endocrine function of the pituitary as well as circulating IGF-1 levels were preserved (Selman et al. 2008). Additionally, female IRS-1\% mice were hyperinsulinemic and IGF1 /insulin resistant and rectal temperature was significantly elevated (Selman et al. 2008). All these characteristics are in contrast to the long-lived GH-deficient and GH-resistant mice, however female IRS-1 $/$ - mutants have similar alterations in expression of genes involved in oxidative stress defence and DNA repair (Selman et al. 2008). In the same study, no significant increase of lifespan was found for male IRS-1 $/$ - mice, as well as for IRS-1+/- and IRS-2+/- mice of both sexes, and IRS-2/- mice were even short-lived (Selman et al. 2008).

IRS-2+/- mice were found to be long-lived, slightly larger and more insulin sensitive and glucose tolerant than wild-type mice (Taguchi, Wartschow, and White 2007). However, the animals studied by Selman et al. (2008) were fed a 'standard' rodent diet with a fat content of $5 \%$, while those studied by Taguchi et al. (2007) were on a 'high energy' diet with a fat content of $9 \%$, hence indicating that the IRS-2+/- mice might be protected from the harming effects of a high-fat diet (Bartke 2008). In addition, Taguchi et al. (2007) reported that brain specific alterations of IRS-2 in bIRS-2+/- and bIRS-2 $/$ mice result in increased lifespan despite glucose and insulin resistance (Taguchi, Wartschow, and White 2007). Further work will be needed to clarify and reconcile the observations made in those two laboratories (Bartke 2008).

Regardless the criticism on the reproducibility of the observations made by Holzenberger (Kappeler et al. 2008) and Taguchi (2007), they provide evidence that selective disruption of the IIS pathway in neurons might not only extend lifespan in C.elegans and Drosophila (Wolkow et al. 2000; Kenyon 2005) but also in mammals. These findings may indirectly be verified by other studies that demonstrate a protection from AD pathology in a transgenic AD mouse model via deletion of IGF-1R or IRS-2 (Cohen et al. 2009; Freude et al. 2009; Killick et al. 2009).

\subsection{IGF-1 signalling and its relevance to human longevity}

The IIS pathway is highly conserved throughout evolution from nematodes and flies to mammals. In the last years, an increasing body of data suggests that this pathway is important for human longevity as well.

GH secretion and IGF-1 levels decrease with age (Rudman et al. 1981), which contributes to ageing-associated changes in body composition such as increased adipose tissue and reduced lean body mass leading to impaired insulin sensitivity and cardiovascular disease. The same observations are made in patients with GH deficiency (Khan et al. 2001) and mutation in the GHR gene: Low serum IGF-1 levels, short stature, obesity, glucose intolerance and possible mental retardation but no decrease in life expectancy (Rincon, Rudin, and Barzilai 2005). Conversely, pathologic GH excess in acromegaly leads to reduced life expectancy due to cardiovascular disease, diabetes and malignancies (Orme et al. 1998). Additionally, body height has been identified as a cancer risk in a number of large 
population studies (Bartke 2011) and serum IGF-1 levels correlate with cancer mortality in elderly men (Major et al. 2010). Therefore, the decline of GH secretion in the process of ageing might not simply reflect a progressive failure of the hypothalamus-somatotrope axis, but might be protective for the development of insulin resistance and cancer (Bartke 2003; Shechter et al. 2007). GH/IGF-1 therapy in elderly and GH deficient patients improves the ratio of lean and fat body mass, the lipid profile, protein synthesis, bone density, immune functions and memory (Khan et al. 2001), but certainly bears adverse side-effects, as GH is known to be diabetogenic and IGF-1 might increase the risk of cancer (Juul 1999; Khan et al. 2001; Pollak, Schernhammer, and Hankinson 2004; Major et al. 2010).

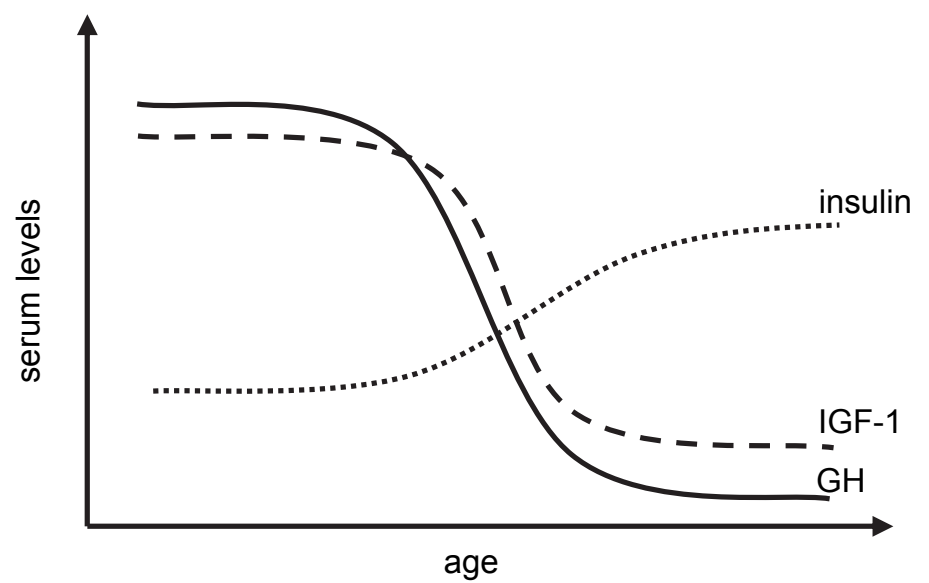

resulting changes

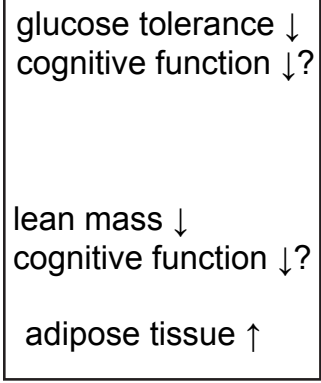

Fig. 4. GH/IGF-1 in ageing

Serum levels of growth hormone (GH) and insulin-like growth factor-1 (IGF-1) decrease during ageing contributing to increased fat mass and decreased lean mass and might influence cognitive function negatively. Serum insulin levels increase with age indicating age-associated insulin insensitivity possibly leading to impaired glucose tolerance and diabetes.

Recently, a study on a cohort of Ecuadorian patients carrying mutations in the GHR gene was published after 22 years of monitoring. Patients demonstrated severe GH resistance and reduced circulating IGF-1 and IGF-2 levels resulting in short stature (Guevara-Aguirre et al. 2011). No extension in lifespan was found in this cohort, which is in contrast to the GHR deficient mouse model (Guevara-Aguirre et al. 2011). However, causes of death were different in unaffected relatives compared to GHR deficient subjects, which died much more frequently from accidents, alcohol-related diseases and convulsive disorders, which might be the reason for unchanged lifespan (Guevara-Aguirre et al. 2011). Cancer accounted for 17 $\%$ and diabetes for $5 \%$ of all diseases in non-affected relatives, whereas only one nonlethal malignancy and no cases of diabetes, probably due to improved insulin sensitivity, were reported for the individuals with GHR mutations (Guevara-Aguirre et al. 2011). Importantly, GHR deficient subjects appear to have no increased mortality from vascular diseases compared to their relatives (30\% of deaths verses $33 \%$ of deaths in the nonaffected relatives), however the proportion of strokes (3\% verses $12 \%$ ) and cardiac disease (27\% verses $21 \%$ ) was slightly different (Guevara-Aguirre et al. 2011). 
In a cohort of Ashkenazi Jewish centenarians, a gender-specific increase in serum IGF-1 associated with smaller stature in female offspring was found to be due to heterozygous mutations in the IGF-1R gene (Suh et al. 2008). These rare mutations were significantly more common in female centenarians and overrepresented compared to controls (Suh et al. 2008). These observations are in line with the IGF-1R+/- mouse model, in which female mice show growth retardation and extended lifespan (Holzenberger et al. 2003) but IGF-1 resistance.

Further studies on human centenarians, mainly screening selectively genes of the IIS pathway, identified certain genes in the insulin/IGF-1 pathway to be important for human longevity. Several cohorts with different genetic background have reported an association of FOXO3A single nucleotide polymorphisms (SNPs) with longevity (Willcox et al. 2008; Flachsbart et al. 2009; Anselmi et al. 2009; Pawlikowska et al. 2009; Li et al. 2009). Interestingly, the study on long-lived Han Chinese revealed a SNP of FOXO1 associated with female longevity exclusively (Li et al. 2009).

Furthermore, in the Leiden 85-plus Study an association of a certain FOXO1 haplotype with higher HbA1c levels, higher prevalence of diabetes, myocardial infarction as well as increased mortality was observed (Kuningas et al. 2007). In addition, a certain haplotype of the FOXO3A gene revealed increased risks for stroke and mortality (Kuningas et al. 2007). These findings indicate that alterations within the FOXO genes might be causative involved in age-associated diseases and regulation of lifespan (Flachsbart et al. 2009).

\section{Conclusion}

Recent studies in different model organisms, including C. elegans, Drosophila melanogaster and Mus musculus have generated piling knowledge about the IIS pathway and its relevance for healthy ageing and longevity. The data obtained in these model organisms have been translated to humans and lead to the identification of the IIS pathway as regulator for human lifespan and ageing.

The GH and IGF-1 signalling pathway plays a key-role in regulating growth and metabolism, and alterations within this pathway have crucial effects on health and lifespan. Model-organisms with reduced GH or IGF-1 signalling are frequently long-lived or show an increased mean lifespan. Interestingly, serum GH and IGF-1 levels decrease with age, and this might be interpreted not solely as progressive failure of the hypothalamus-somatotrope axis but rather as protection for insulin resistance and malignancies.

IGF-1R signalling is required for normal brain development, and acute IGF-1 action might enhance cognitive functions and ameliorates ischemic or traumatic brain injuries. Additionally, recent studies demonstrate that IGF-1R signalling or the number of IGF-1Rs in the brain during early development determines metabolism and possibly age-associated diseases indicating a role of IGF-1 mediated signals as neuroendocrine regulator of health and lifespan.

Foxo-transcription factors have been identified as main downstream-target of IIS and seem to be essential for activating gene transcripton that mediates longevity. Furthermore, genomic screening of centenarians with different genetic background found matching SNPs or haplotypes in the FOXO3A gene suggesting a key-role of FOXO3A in influencing lifespan not only in model organisms but also in humans.

However, the role of IIS in AD still raises questions, as the impaired signalling might be cause or consequence of neurodegeneration. 
Therapeutic approaches altering the IIS pathway might not only improve treatment of neurodegenerative disorders but provide a possibility to prevent ageing-associated diseases in the future.

\section{References}

Alcedo, J., and C. Kenyon. (2004). Regulation of C. elegans longevity by specific gustatory and olfactory neurons. Neuron 41 (1):45-55.

Alessi, D. R., M. Andjelkovic, B. Caudwell, P. Cron, N. Morrice, P. Cohen, and B. A. Hemmings. (1996). Mechanism of activation of protein kinase B by insulin and IGF-1. EMBO J 15 (23):6541-51.

Altman, J., and S. A. Bayer. (1990). Migration and distribution of two populations of hippocampal granule cell precursors during the perinatal and postnatal periods. $J$ Comp Neurol 301 (3):365-81.

Altman, J., and S. A. Bayer. (1990). Mosaic organization of the hippocampal neuroepithelium and the multiple germinal sources of dentate granule cells. J Comp Neurol 301 (3):32542.

Alzheimer, A., R. A. Stelzmann, H. N. Schnitzlein, and F. R. Murtagh. (1995). An English translation of Alzheimer's 1907 paper, "Uber eine eigenartige Erkankung der Hirnrinde". Clin Anat 8 (6):429-31.

Anselmi, C. V., A. Malovini, R. Roncarati, V. Novelli, F. Villa, G. Condorelli, R. Bellazzi, and A. A. Puca. (2009). Association of the FOXO3A locus with extreme longevity in a southern Italian centenarian study. Rejuvenation Res 12 (2):95-104.

Arimon, M., I. Diez-Perez, M. J. Kogan, N. Durany, E. Giralt, F. Sanz, and X. FernandezBusquets. (2005). Fine structure study of Abeta1-42 fibrillogenesis with atomic force microscopy. FASEB J 19 (10):1344-6.

Astrinidis, A., and E. P. Henske. (2005). Tuberous sclerosis complex: linking growth and energy signaling pathways with human disease. Oncogene 24 (50):7475-81.

Baker, J., J. P. Liu, E. J. Robertson, and A. Efstratiadis. (1993). Role of insulin-like growth factors in embryonic and postnatal growth. Cell 75 (1):73-82.

Ballard, F. J., J. C. Wallace, G. L. Francis, L. C. Read, and F. M. Tomas. (1996). Des(1-3)IGF-I: a truncated form of insulin-like growth factor-I. Int J Biochem Cell Biol 28 (10):1085-7.

Ballatore, C., V. M. Lee, and J. Q. Trojanowski. (2007). Tau-mediated neurodegeneration in Alzheimer's disease and related disorders. Nat Rev Neurosci 8 (9):663-72.

Barrow, C. J., and M. G. Zagorski. (1991). Solution structures of beta peptide and its constituent fragments: relation to amyloid deposition. Science 253 (5016):179-82.

Bartke, A. (2003). Is growth hormone deficiency a beneficial adaptation to aging? Evidence from experimental animals. Trends Endocrinol Metab 14 (7):340-4.

Bartke, A. (2006). New findings in transgenic, gene knockout and mutant mice. Exp Gerontol 41 (12):1217-9.

Bartke, A. (2008). Impact of reduced insulin-like growth factor-1/insulin signaling on aging in mammals: novel findings. Aging Cell 7 (3):285-90.

Bartke, A. (2011). Growth hormone, insulin and aging: the benefits of endocrine defects. Exp Gerontol 46 (2-3):108-11.

Bartke, A., and H. Brown-Borg. (2004). Life extension in the dwarf mouse. Curr Top Dev Biol 63:189-225. 
Bartke, A., H. Brown-Borg, J. Mattison, B. Kinney, S. Hauck, and C. Wright. (2001). Prolonged longevity of hypopituitary dwarf mice. Exp Gerontol 36 (1):21-8.

Bateman, J. M., and H. McNeill. (2006). Insulin/IGF signalling in neurogenesis. Cell Mol Life Sci 63 (15):1701-5.

Bauer, J. H., C. Chang, S. N. Morris, S. Hozier, S. Andersen, J. S. Waitzman, and S. L. Helfand. (2007). Expression of dominant-negative Dmp53 in the adult fly brain inhibits insulin signaling. Proc Natl Acad Sci U S A 104 (33):13355-60.

Bauer, J. H., P. C. Poon, H. Glatt-Deeley, J. M. Abrams, and S. L. Helfand. (2005). Neuronal expression of p53 dominant-negative proteins in adult Drosophila melanogaster extends life span. Curr Biol 15 (22):2063-8.

Baxter, R. C. (1988). Characterization of the acid-labile subunit of the growth hormonedependent insulin-like growth factor binding protein complex. J Clin Endocrinol Metab 67 (2):265-72.

Baxter, R. C. (2000). Insulin-like growth factor (IGF)-binding proteins: interactions with IGFs and intrinsic bioactivities. Am J Physiol Endocrinol Metab 278 (6):E967-76.

Baxter, R. C., and J. L. Martin. (1989). Structure of the Mr 140,000 growth hormone-dependent insulin-like growth factor binding protein complex: determination by reconstitution and affinity-labeling. Proc Natl Acad Sci U S A 86 (18):6898-902.

Baxter, R. C., J. L. Martin, and V. A. Beniac. (1989). High molecular weight insulin-like growth factor binding protein complex. Purification and properties of the acid-labile subunit from human serum. J Biol Chem 264 (20):11843-8.

Baxter, R. C., S. Meka, and S. M. Firth. (2002). Molecular distribution of IGF binding protein-5 in human serum. J Clin Endocrinol Metab 87 (1):271-6.

Beck, K. D., L. Powell-Braxton, H. R. Widmer, J. Valverde, and F. Hefti. (1995). Igf1 gene disruption results in reduced brain size, CNS hypomyelination, and loss of hippocampal granule and striatal parvalbumin-containing neurons. Neuron 14 (4):717-30.

Berryman, D. E., E. O. List, K. T. Coschigano, K. Behar, J. K. Kim, and J. J. Kopchick. (2004). Comparing adiposity profiles in three mouse models with altered $\mathrm{GH}$ signaling. Growth Horm IGF Res 14 (4):309-18.

Berryman, D. E., E. O. List, D. T. Kohn, K. T. Coschigano, R. J. Seeley, and J. J. Kopchick. (2006). Effect of growth hormone on susceptibility to diet-induced obesity. Endocrinology 147 (6):2801-8.

Bertolotto, C., L. Maulon, N. Filippa, G. Baier, and P. Auberger. (2000). Protein kinase C theta and epsilon promote T-cell survival by a rsk-dependent phosphorylation and inactivation of BAD. J Biol Chem 275 (47):37246-50.

Bertram, L., and R. E. Tanzi. (2005). The genetic epidemiology of neurodegenerative disease. J Clin Invest 115 (6):1449-57.

Bick, T., Z. Hochberg, T. Amit, O. G. Isaksson, and J. O. Jansson. (1992). Roles of pulsatility and continuity of growth hormone (GH) administration in the regulation of hepatic GHreceptors, and circulating GH-binding protein and insulin-like growth factor-I. Endocrinology 131 (1):423-9.

Biggs, W. H., 3rd, J. Meisenhelder, T. Hunter, W. K. Cavenee, and K. C. Arden. (1999). Protein kinase B/Akt-mediated phosphorylation promotes nuclear exclusion of the winged helix transcription factor FKHR1. Proc Natl Acad Sci U S A 96 (13):7421-6. 
Birkenkamp, K. U., and P. J. Coffer. (2003). Regulation of cell survival and proliferation by the FOXO (Forkhead box, class O) subfamily of Forkhead transcription factors. Biochem Soc Trans 31 (Pt 1):292-7.

Bluher, M., B. B. Kahn, and C. R. Kahn. (2003). Extended longevity in mice lacking the insulin receptor in adipose tissue. Science 299 (5606):572-4.

Bohannon, N. J., E. S. Corp, B. J. Wilcox, D. P. Figlewicz, D. M. Dorsa, and D. G. Baskin. (1988). Characterization of insulin-like growth factor I receptors in the median eminence of the brain and their modulation by food restriction. Endocrinology 122 (5):1940-7.

Bohlooly, Y. M., B. Olsson, A. Gritli-Linde, O. Brusehed, O. G. Isaksson, C. Ohlsson, B. Soderpalm, and J. Tornell. (2001). Enhanced spontaneous locomotor activity in bovine GH transgenic mice involves peripheral mechanisms. Endocrinology 142 (10):4560-7.

Boisclair, Y. R., R. P. Rhoads, I. Ueki, J. Wang, and G. T. Ooi. (2001). The acid-labile subunit (ALS) of the $150 \mathrm{kDa}$ IGF-binding protein complex: an important but forgotten component of the circulating IGF system. J Endocrinol 170 (1):63-70.

Bondy, C. A., and W. H. Lee. (1993). Patterns of insulin-like growth factor and IGF receptor gene expression in the brain. Functional implications. Ann N Y Acad Sci 692:33-43.

Bondy, C. A., H. Werner, C. T. Roberts, Jr., and D. LeRoith. (1990). Cellular pattern of insulinlike growth factor-I (IGF-I) and type I IGF receptor gene expression in early organogenesis: comparison with IGF-II gene expression. Mol Endocrinol 4 (9):1386-98.

Bondy, C., and W. H. Lee. (1993). Correlation between insulin-like growth factor (IGF)-binding protein 5 and IGF-I gene expression during brain development. J Neurosci 13 (12):5092-104.

Bondy, C., H. Werner, C. T. Roberts, Jr., and D. LeRoith. (1992). Cellular pattern of type-I insulin-like growth factor receptor gene expression during maturation of the rat brain: comparison with insulin-like growth factors I and II. Neuroscience 46 (4):909-23.

Bonkowski, M. S., R. W. Pamenter, J. S. Rocha, M. M. Masternak, J. A. Panici, and A. Bartke. (2006). Long-lived growth hormone receptor knockout mice show a delay in agerelated changes of body composition and bone characteristics. J Gerontol A Biol Sci Med Sci 61 (6):562-7.

Boura-Halfon, S., and Y. Zick. (2009). Phosphorylation of IRS proteins, insulin action, and insulin resistance. Am J Physiol Endocrinol Metab 296 (4):E581-91.

Braulke, T. (1999). Type-2 IGF receptor: a multi-ligand binding protein. Horm Metab Res 31 (23):242-6.

Broughton, S. J., M. D. Piper, T. Ikeya, T. M. Bass, J. Jacobson, Y. Driege, P. Martinez, E. Hafen, D. J. Withers, S. J. Leevers, and L. Partridge. (2005). Longer lifespan, altered metabolism, and stress resistance in Drosophila from ablation of cells making insulinlike ligands. Proc Natl Acad Sci U S A 102 (8):3105-10.

Broughton, S., and L. Partridge. (2009). Insulin/IGF-like signalling, the central nervous system and aging. Biochem J 418 (1):1-12.

Brown-Borg, H. M., K. E. Borg, C. J. Meliska, and A. Bartke. (1996). Dwarf mice and the ageing process. Nature 384 (6604):33.

Brunet, A., A. Bonni, M. J. Zigmond, M. Z. Lin, P. Juo, L. S. Hu, M. J. Anderson, K. C. Arden, J. Blenis, and M. E. Greenberg. (1999). Akt promotes cell survival by phosphorylating and inhibiting a Forkhead transcription factor. Cell 96 (6):857-68. 
Brunet, A., D. Roux, P. Lenormand, S. Dowd, S. Keyse, and J. Pouyssegur. (1999). Nuclear translocation of $\mathrm{p} 42 / \mathrm{p} 44$ mitogen-activated protein kinase is required for growth factor-induced gene expression and cell cycle entry. EMBO J 18 (3):664-74.

Brunet, A., L. B. Sweeney, J. F. Sturgill, K. F. Chua, P. L. Greer, Y. Lin, H. Tran, S. E. Ross, R. Mostoslavsky, H. Y. Cohen, L. S. Hu, H. L. Cheng, M. P. Jedrychowski, S. P. Gygi, D. A. Sinclair, F. W. Alt, and M. E. Greenberg. (2004). Stress-dependent regulation of FOXO transcription factors by the SIRT1 deacetylase. Science 303 (5666):2011-5.

Bruning, J. C., D. Gautam, D. J. Burks, J. Gillette, M. Schubert, P. C. Orban, R. Klein, W. Krone, D. Muller-Wieland, and C. R. Kahn. (2000). Role of brain insulin receptor in control of body weight and reproduction. Science 289 (5487):2122-5.

Busby, W. H., Jr., T. J. Nam, A. Moralez, C. Smith, M. Jennings, and D. R. Clemmons. (2000). The complement component $\mathrm{C} 1 \mathrm{~s}$ is the protease that accounts for cleavage of insulinlike growth factor-binding protein-5 in fibroblast medium. J Biol Chem 275 (48):3763844.

Butler, A. A., and D. Le Roith. (2001). Control of growth by the somatropic axis: growth hormone and the insulin-like growth factors have related and independent roles. Annu Rev Physiol 63:141-64.

Butler, A. A., and D. LeRoith. (2001). Minireview: tissue-specific versus generalized gene targeting of the igf1 and igf1r genes and their roles in insulin-like growth factor physiology. Endocrinology 142 (5):1685-8.

Byun, D., S. Mohan, M. Yoo, C. Sexton, D. J. Baylink, and X. Qin. (2001). Pregnancy-associated plasma protein-A accounts for the insulin-like growth factor (IGF)-binding protein-4 (IGFBP-4) proteolytic activity in human pregnancy serum and enhances the mitogenic activity of IGF by degrading IGFBP-4 in vitro. J Clin Endocrinol Metab 86 (2):847-54.

Carlsson-Skwirut, C., M. Lake, M. Hartmanis, K. Hall, and V. R. Sara. (1989). A comparison of the biological activity of the recombinant intact and truncated insulin-like growth factor 1 (IGF-1). Biochim Biophys Acta 1011 (2-3):192-7.

Carlsson, L., and J. O. Jansson. (1990). Endogenous growth hormone (GH) secretion in male rats is synchronized to pulsatile GH infusions given at 3-hour intervals. Endocrinology $126(1): 6-10$.

Carro, E., A. Nunez, S. Busiguina, and I. Torres-Aleman. (2000). Circulating insulin-like growth factor I mediates effects of exercise on the brain. J Neurosci 20 (8):2926-33.

Carro, E., C. Spuch, J. L. Trejo, D. Antequera, and I. Torres-Aleman. (2005). Choroid plexus megalin is involved in neuroprotection by serum insulin-like growth factor I. $J$ Neurosci 25 (47):10884-93.

Carro, E., J. L. Trejo, T. Gomez-Isla, D. LeRoith, and I. Torres-Aleman. (2002). Serum insulinlike growth factor I regulates brain amyloid-beta levels. Nat Med 8 (12):1390-7.

Carro, E., J. L. Trejo, C. Spuch, D. Bohl, J. M. Heard, and I. Torres-Aleman. (2006). Blockade of the insulin-like growth factor I receptor in the choroid plexus originates Alzheimer'slike neuropathology in rodents: new cues into the human disease? Neurobiol Aging 27 (11):1618-31.

Carson, M. J., R. R. Behringer, R. L. Brinster, and F. A. McMorris. (1993). Insulin-like growth factor I increases brain growth and central nervous system myelination in transgenic mice. Neuron 10 (4):729-40. 
Cheatham, B., and C. R. Kahn. (1995). Insulin action and the insulin signaling network. Endocr Rev 16 (2):117-42.

Chen, J., P. R. Somanath, O. Razorenova, W. S. Chen, N. Hay, P. Bornstein, and T. V. Byzova. (2005). Akt1 regulates pathological angiogenesis, vascular maturation and permeability in vivo. Nat Med 11 (11):1188-96.

Cheng, C. M., V. Tseng, J. Wang, D. Wang, L. Matyakhina, and C. A. Bondy. (2005). Tau is hyperphosphorylated in the insulin-like growth factor-I null brain. Endocrinology 146 (12):5086-91.

Cho, J. H., and G. V. Johnson. (2004). Primed phosphorylation of tau at Thr231 by glycogen synthase kinase 3beta (GSK3beta) plays a critical role in regulating tau's ability to bind and stabilize microtubules. J Neurochem 88 (2):349-58.

Chou, C. K., T. J. Dull, D. S. Russell, R. Gherzi, D. Lebwohl, A. Ullrich, and O. M. Rosen. (1987). Human insulin receptors mutated at the ATP-binding site lack protein tyrosine kinase activity and fail to mediate postreceptor effects of insulin. J Biol Chem 262 (4):1842-7.

Chromy, B. A., R. J. Nowak, M. P. Lambert, K. L. Viola, L. Chang, P. T. Velasco, B. W. Jones, S. J. Fernandez, P. N. Lacor, P. Horowitz, C. E. Finch, G. A. Krafft, and W. L. Klein. (2003). Self-assembly of Abeta(1-42) into globular neurotoxins. Biochemistry 42 (44):12749-60.

Chrysis, D., A. S. Calikoglu, P. Ye, and A. J. D'Ercole. (2001). Insulin-like growth factor-I overexpression attenuates cerebellar apoptosis by altering the expression of $\mathrm{Bcl}$ family proteins in a developmentally specific manner. J Neurosci 21 (5):1481-9.

Citron, M. (2002). Alzheimer's disease: treatments in discovery and development. Nat Neurosci 5 Suppl:1055-7.

Clancy, D. J., D. Gems, L. G. Harshman, S. Oldham, H. Stocker, E. Hafen, S. J. Leevers, and L. Partridge. (2001). Extension of life-span by loss of CHICO, a Drosophila insulin receptor substrate protein. Science 292 (5514):104-6.

Clark, K. L., E. D. Halay, E. Lai, and S. K. Burley. (1993). Co-crystal structure of the HNF3/fork head DNA-recognition motif resembles histone H5. Nature 364 (6436):412-20.

Clark, R. G., J. O. Jansson, O. Isaksson, and I. C. Robinson. (1985). Intravenous growth hormone: growth responses to patterned infusions in hypophysectomized rats. $J$ Endocrinol 104 (1):53-61.

Cleary, J. P., D. M. Walsh, J. J. Hofmeister, G. M. Shankar, M. A. Kuskowski, D. J. Selkoe, and K. H. Ashe. (2005). Natural oligomers of the amyloid-beta protein specifically disrupt cognitive function. Nat Neurosci 8 (1):79-84.

Cohen, E., J. Bieschke, R. M. Perciavalle, J. W. Kelly, and A. Dillin. (2006). Opposing activities protect against age-onset proteotoxicity. Science 313 (5793):1604-10.

Cohen, E., J. F. Paulsson, P. Blinder, T. Burstyn-Cohen, D. Du, G. Estepa, A. Adame, H. M. Pham, M. Holzenberger, J. W. Kelly, E. Masliah, and A. Dillin. (2009). Reduced IGF-1 signaling delays age-associated proteotoxicity in mice. Cell 139 (6):1157-69.

Cohick, W. S., and D. R. Clemmons. (1993). The insulin-like growth factors. Annu Rev Physiol 55:131-53.

Cole, A. R., A. Astell, C. Green, and C. Sutherland. (2007). Molecular connexions between dementia and diabetes. Neurosci Biobehav Rev 31 (7):1046-63. 
Coles, M., W. Bicknell, A. A. Watson, D. P. Fairlie, and D. J. Craik. (1998). Solution structure of amyloid beta-peptide(1-40) in a water-micelle environment. Is the membranespanning domain where we think it is? Biochemistry 37 (31):11064-77.

Conover, C. A. (1995). Insulin-like growth factor binding protein proteolysis in bone cell models. Prog Growth Factor Res 6 (2-4):301-9.

Conover, C. A., and L. K. Bale. (2007). Loss of pregnancy-associated plasma protein A extends lifespan in mice. Aging Cell 6 (5):727-9.

Conover, C. A., L. K. Bale, M. T. Overgaard, E. W. Johnstone, U. H. Laursen, E. M. Fuchtbauer, C. Oxvig, and J. van Deursen. (2004). Metalloproteinase pregnancy-associated plasma protein A is a critical growth regulatory factor during fetal development. Development 131 (5):1187-94.

Conover, C. A., G. F. Faessen, K. E. Ilg, Y. A. Chandrasekher, M. Christiansen, M. T. Overgaard, C. Oxvig, and L. C. Giudice. (2001). Pregnancy-associated plasma protein$\mathrm{a}$ is the insulin-like growth factor binding protein-4 protease secreted by human ovarian granulosa cells and is a marker of dominant follicle selection and the corpus luteum. Endocrinology 142 (5):2155.

Coschigano, K. T., D. Clemmons, L. L. Bellush, and J. J. Kopchick. (2000). Assessment of growth parameters and life span of GHR/BP gene-disrupted mice. Endocrinology 141 (7):2608-13.

Coschigano, K. T., A. N. Holland, M. E. Riders, E. O. List, A. Flyvbjerg, and J. J. Kopchick. (2003). Deletion, but not antagonism, of the mouse growth hormone receptor results in severely decreased body weights, insulin, and insulin-like growth factor I levels and increased life span. Endocrinology 144 (9):3799-810.

Costantini, C., H. Scrable, and L. Puglielli. (2006). An aging pathway controls the TrkA to p75NTR receptor switch and amyloid beta-peptide generation. EMBO J 25 (9):19972006.

Couce, M. E., A. J. Weatherington, and J. F. McGinty. (1992). Expression of insulin-like growth factor-II (IGF-II) and IGF-II/mannose-6-phosphate receptor in the rat hippocampus: an in situ hybridization and immunocytochemical study. Endocrinology 131 (4):163642.

Crescenzi, O., S. Tomaselli, R. Guerrini, S. Salvadori, A. M. D'Ursi, P. A. Temussi, and D. Picone. (2002). Solution structure of the Alzheimer amyloid beta-peptide (1-42) in an apolar microenvironment. Similarity with a virus fusion domain. Eur J Biochem 269 (22):5642-8.

D'Ercole, A. J., Z. Dai, Y. Xing, C. Boney, M. B. Wilkie, J. M. Lauder, V. K. Han, and D. R. Clemmons. (1994). Brain growth retardation due to the expression of human insulin like growth factor binding protein-1 in transgenic mice: an in vivo model for the analysis of igf function in the brain. Brain Res Dev Brain Res 82 (1-2):213-22.

Dahlgren, K. N., A. M. Manelli, W. B. Stine, Jr., L. K. Baker, G. A. Krafft, and M. J. LaDu. (2002). Oligomeric and fibrillar species of amyloid-beta peptides differentially affect neuronal viability. J Biol Chem 277 (35):32046-53.

Daitoku, H., M. Hatta, H. Matsuzaki, S. Aratani, T. Ohshima, M. Miyagishi, T. Nakajima, and A. Fukamizu. (2004). Silent information regulator 2 potentiates Foxo1-mediated transcription through its deacetylase activity. Proc Natl Acad Sci U S A 101 (27):100427. 
de la Torre-Ubieta, L., B. Gaudilliere, Y. Yang, Y. Ikeuchi, T. Yamada, S. DiBacco, J. Stegmuller, U. Schuller, D. A. Salih, D. Rowitch, A. Brunet, and A. Bonni. (2010). A FOXO-Pak1 transcriptional pathway controls neuronal polarity. Genes Dev 24 (8):799-813.

De Strooper, B. (2003). Aph-1, Pen-2, and Nicastrin with Presenilin generate an active gammaSecretase complex. Neuron 38 (1):9-12.

Deitel, K., D. Dantzer, P. Ferguson, M. Pollak, W. Beamer, I. Andrulis, and R. Bell. (2002). Reduced growth of human sarcoma xenografts in hosts homozygous for the lit mutation. J Surg Oncol 81 (2):75-9.

Dijkers, P. F., R. H. Medema, J. W. Lammers, L. Koenderman, and P. J. Coffer. (2000). Expression of the pro-apoptotic Bcl-2 family member Bim is regulated by the forkhead transcription factor FKHR-L1. Curr Biol 10 (19):1201-4.

Dijkers, P. F., R. H. Medema, C. Pals, L. Banerji, N. S. Thomas, E. W. Lam, B. M. Burgering, J. A. Raaijmakers, J. W. Lammers, L. Koenderman, and P. J. Coffer. (2000). Forkhead transcription factor FKHR-L1 modulates cytokine-dependent transcriptional regulation of p27(KIP1). Mol Cell Biol 20 (24):9138-48.

Dong, M. Q., J. D. Venable, N. Au, T. Xu, S. K. Park, D. Cociorva, J. R. Johnson, A. Dillin, and J. R. Yates, 3rd. (2007). Quantitative mass spectrometry identifies insulin signaling targets in C. elegans. Science 317 (5838):660-3.

Dore, S., S. Kar, and R. Quirion. (1997). Presence and differential internalization of two distinct insulin-like growth factor receptors in rat hippocampal neurons. Neuroscience 78 (2):373-83.

Duan, C., and Q. Xu. (2005). Roles of insulin-like growth factor (IGF) binding proteins in regulating IGF actions. Gen Comp Endocrinol 142 (1-2):44-52.

Duffy, K. R., W. M. Pardridge, and R. G. Rosenfeld. (1988). Human blood-brain barrier insulinlike growth factor receptor. Metabolism 37 (2):136-40.

Edwards, D. C., L. C. Sanders, G. M. Bokoch, and G. N. Gill. (1999). Activation of LIM-kinase by Pak1 couples Rac/Cdc42 GTPase signalling to actin cytoskeletal dynamics. Nat Cell Biol 1 (5):253-9.

Essers, M. A., S. Weijzen, A. M. de Vries-Smits, I. Saarloos, N. D. de Ruiter, J. L. Bos, and B. M. Burgering. (2004). FOXO transcription factor activation by oxidative stress mediated by the small GTPase Ral and JNK. EMBO J 23 (24):4802-12.

Firth, S. M., and R. C. Baxter. (2002). Cellular actions of the insulin-like growth factor binding proteins. Endocr Rev 23 (6):824-54.

Flachsbart, F., A. Caliebe, R. Kleindorp, H. Blanche, H. von Eller-Eberstein, S. Nikolaus, S. Schreiber, and A. Nebel. (2009). Association of FOXO3A variation with human longevity confirmed in German centenarians. Proc Natl Acad Sci U S A 106 (8):2700-5.

Flaherty, D. B., J. P. Soria, H. G. Tomasiewicz, and J. G. Wood. (2000). Phosphorylation of human tau protein by microtubule-associated kinases: GSK3beta and cdk5 are key participants. J Neurosci Res 62 (3):463-72.

Flurkey, K., J. Papaconstantinou, R. A. Miller, and D. E. Harrison. (2001). Lifespan extension and delayed immune and collagen aging in mutant mice with defects in growth hormone production. Proc Natl Acad Sci U S A 98 (12):6736-41.

Fowlkes, J. L., K. M. Thrailkill, D. M. Serra, K. Suzuki, and H. Nagase. (1995). Matrix metalloproteinases as insulin-like growth factor binding protein-degrading proteinases. Prog Growth Factor Res 6 (2-4):255-63. 
Francis, G. L., F. M. Upton, F. J. Ballard, K. A. McNeil, and J. C. Wallace. (1988). Insulin-like growth factors 1 and 2 in bovine colostrum. Sequences and biological activities compared with those of a potent truncated form. Biochem J 251 (1):95-103.

Frasca, F., G. Pandini, P. Scalia, L. Sciacca, R. Mineo, A. Costantino, I. D. Goldfine, A. Belfiore, and R. Vigneri. (1999). Insulin receptor isoform A, a newly recognized, high-affinity insulin-like growth factor II receptor in fetal and cancer cells. Mol Cell Biol 19 (5):327888.

Fratiglioni, L., S. Paillard-Borg, and B. Winblad. (2004). An active and socially integrated lifestyle in late life might protect against dementia. Lancet Neurol 3 (6):343-53.

Freude, S., M. M. Hettich, C. Schumann, O. Stohr, L. Koch, C. Kohler, M. Udelhoven, U. Leeser, M. Muller, N. Kubota, T. Kadowaki, W. Krone, H. Schroder, J. C. Bruning, and M. Schubert. (2009). Neuronal IGF-1 resistance reduces Abeta accumulation and protects against premature death in a model of Alzheimer's disease. FASEB J 23 (10):3315-24.

Freude, S., K. Schilbach, and M. Schubert. (2009). The role of IGF-1 receptor and insulin receptor signaling for the pathogenesis of Alzheimer's disease: from model organisms to human disease. Curr Alzheimer Res 6 (3):213-23.

Frohman, L. A., and J. O. Jansson. (1986). Growth hormone-releasing hormone. Endocr Rev 7 (3):223-53.

Frolich, L., D. Blum-Degen, H. G. Bernstein, S. Engelsberger, J. Humrich, S. Laufer, D. Muschner, A. Thalheimer, A. Turk, S. Hoyer, R. Zochling, K. W. Boissl, K. Jellinger, and P. Riederer. (1998). Brain insulin and insulin receptors in aging and sporadic Alzheimer's disease. J Neural Transm 105 (4-5):423-38.

Frolich, L., D. Blum-Degen, P. Riederer, and S. Hoyer. (1999). A disturbance in the neuronal insulin receptor signal transduction in sporadic Alzheimer's disease. Ann N Y Acad Sci 893:290-3.

Fruman, D. A., R. E. Meyers, and L. C. Cantley. (1998). Phosphoinositide kinases. Annu Rev Biochem 67:481-507.

Fruman, D.A., L.E. Rameh, and L.C. Cantley. (1999). Phosphoinositide binding domains: Embracing 3-phosphate. Cell. 97(7):817-820

Furuyama, T., T. Nakazawa, I. Nakano, and N. Mori. (2000). Identification of the differential distribution patterns of mRNAs and consensus binding sequences for mouse DAF-16 homologues. Biochem J 349 (Pt 2):629-34.

Gage, P. J., M. L. Roller, T. L. Saunders, L. M. Scarlett, and S. A. Camper. (1996). Anterior pituitary cells defective in the cell-autonomous factor, $\mathrm{df}$, undergo cell lineage specification but not expansion. Development 122 (1):151-60.

Garcia-Segura, L. M., J. Perez, S. Pons, M. T. Rejas, and I. Torres-Aleman. (1991). Localization of insulin-like growth factor I (IGF-I)-like immunoreactivity in the developing and adult rat brain. Brain Res 560 (1-2):167-74.

Georganopoulou, D. G., L. Chang, J. M. Nam, C. S. Thaxton, E. J. Mufson, W. L. Klein, and C. A. Mirkin. (2005). Nanoparticle-based detection in cerebral spinal fluid of a soluble pathogenic biomarker for Alzheimer's disease. Proc Natl Acad Sci U S A 102 (7):2273-6.

Ghahary, A., E. E. Tredget, Q. Shen, R. T. Kilani, P. G. Scott, and Y. Houle. (2000). Mannose-6phosphate/IGF-II receptors mediate the effects of IGF-1-induced latent transforming growth factor beta 1 on expression of type I collagen and collagenase in dermal fibroblasts. Growth Factors 17 (3):167-76. 
Giovannone, B., M.L. Scaldaferri, M. Federici, O. Porzio, D. Lauro, A. Fusco, P. Sbraccia, P. Borboni, R. Lauro and G. Sesti. Insulin receptor substrate (IRS) transduction system: distinct and overlapping signaling potential. (2000). Diabetes Metab Res Rev. 16(6):434441.

Giustina, A., and J. D. Veldhuis. (1998). Pathophysiology of the neuroregulation of growth hormone secretion in experimental animals and the human. Endocr Rev 19 (6):717-97.

Goedert, M., and M. G. Spillantini. (2006). A century of Alzheimer's disease. Science 314 (5800):777-81.

Goldberg, J. L. (2004). Intrinsic neuronal regulation of axon and dendrite growth. Curr Opin Neurobiol 14 (5):551-7.

Goldgaber, D., M. I. Lerman, O. W. McBride, U. Saffiotti, and D. C. Gajdusek. (1987). Characterization and chromosomal localization of a cDNA encoding brain amyloid of Alzheimer's disease. Science 235 (4791):877-80.

Goldstein, B. J., and C. R. Kahn. (1989). Analysis of mRNA heterogeneity by ribonuclease H mapping: application to the insulin receptor. Biochem Biophys Res Commun 159 (2):6649.

Gotz, J., L. M. Ittner, and S. Kins. (2006). Do axonal defects in tau and amyloid precursor protein transgenic animals model axonopathy in Alzheimer's disease? J Neurochem 98 (4):993-1006.

Gual, P., T. Gremeaux, T. Gonzalez, Y. Le Marchand-Brustel, and J. F. Tanti. (2003). MAP kinases and mTOR mediate insulin-induced phosphorylation of insulin receptor substrate-1 on serine residues 307, 612 and 632. Diabetologia 46 (11):1532-42.

Gual, P., Y. Le Marchand-Brustel, and J. F. Tanti. (2005). Positive and negative regulation of insulin signaling through IRS-1 phosphorylation. Biochimie 87 (1):99-109.

Guan, J., H. J. Waldvogel, R. L. Faull, P. D. Gluckman, and C. E. Williams. (1999). The effects of the N-terminal tripeptide of insulin-like growth factor-1, glycine-proline-glutamate in different regions following hypoxic-ischemic brain injury in adult rats. Neuroscience 89 (3):649-59.

Guevara-Aguirre, J., P. Balasubramanian, M. Guevara-Aguirre, M. Wei, F. Madia, C. W. Cheng, D. Hwang, A. Martin-Montalvo, J. Saavedra, S. Ingles, R. de Cabo, P. Cohen, and V. D. Longo. (2011). Growth hormone receptor deficiency is associated with a major reduction in pro-aging signaling, cancer, and diabetes in humans. Sci Transl Med 3 (70):70ra13.

Guillozet-Bongaarts, A. L., M. E. Cahill, V. L. Cryns, M. R. Reynolds, R. W. Berry, and L. I. Binder. (2006). Pseudophosphorylation of tau at serine 422 inhibits caspase cleavage: in vitro evidence and implications for tangle formation in vivo. J Neurochem 97 (4):1005-14.

Haass, C., and D. J. Selkoe. (2007). Soluble protein oligomers in neurodegeneration: lessons from the Alzheimer's amyloid beta-peptide. Nat Rev Mol Cell Biol 8 (2):101-12.

Hanger, D. P., K. Hughes, J. R. Woodgett, J. P. Brion, and B. H. Anderton. (1992). Glycogen synthase kinase-3 induces Alzheimer's disease-like phosphorylation of tau: generation of paired helical filament epitopes and neuronal localisation of the kinase. Neurosci Lett 147 (1):58-62.

Harada, H., B. Becknell, M. Wilm, M. Mann, L. J. Huang, S. S. Taylor, J. D. Scott, and S. J. Korsmeyer. (1999). Phosphorylation and inactivation of BAD by mitochondriaanchored protein kinase A. Mol Cell 3 (4):413-22. 
Hardy, J., and D. J. Selkoe. (2002). The amyloid hypothesis of Alzheimer's disease: progress and problems on the road to therapeutics. Science 297 (5580):353-6.

Harper, J. D., and P. T. Lansbury, Jr. (1997). Models of amyloid seeding in Alzheimer's disease and scrapie: mechanistic truths and physiological consequences of the timedependent solubility of amyloid proteins. Annu Rev Biochem 66:385-407.

Harper, J. D., S. S. Wong, C. M. Lieber, and P. T. Lansbury, Jr. (1999). Assembly of A beta amyloid protofibrils: an in vitro model for a possible early event in Alzheimer's disease. Biochemistry 38 (28):8972-80.

Harrington, S. C., R. D. Simari, and C. A. Conover. (2007). Genetic deletion of pregnancyassociated plasma protein-A is associated with resistance to atherosclerotic lesion development in apolipoprotein E-deficient mice challenged with a high-fat diet. Circ Res 100 (12):1696-702.

Hauck, S. J., J. M. Aaron, C. Wright, J. J. Kopchick, and A. Bartke. (2002). Antioxidant enzymes, free-radical damage, and response to paraquat in liver and kidney of long-living growth hormone receptor/binding protein gene-disrupted mice. Horm Metab Res 34 (9):481-6.

Hauck, S. J., W. S. Hunter, N. Danilovich, J. J. Kopchick, and A. Bartke. (2001). Reduced levels of thyroid hormones, insulin, and glucose, and lower body core temperature in the growth hormone receptor/binding protein knockout mouse. Exp Biol Med (Maywood) 226 (6):552-8.

Hawkes, C., and S. Kar. (2004). The insulin-like growth factor-II/mannose-6-phosphate receptor: structure, distribution and function in the central nervous system. Brain Res Brain Res Rev 44 (2-3):117-40.

Hayashi, M. L., S. Y. Choi, B. S. Rao, H. Y. Jung, H. K. Lee, D. Zhang, S. Chattarji, A. Kirkwood, and S. Tonegawa. (2004). Altered cortical synaptic morphology and impaired memory consolidation in forebrain- specific dominant-negative PAK transgenic mice. Neuron 42 (5):773-87.

Hayashi, M. L., B. S. Rao, J. S. Seo, H. S. Choi, B. M. Dolan, S. Y. Choi, S. Chattarji, and S. Tonegawa. (2007). Inhibition of p21-activated kinase rescues symptoms of fragile $X$ syndrome in mice. Proc Natl Acad Sci U S A 104 (27):11489-94.

Herschkovitz, A., Y. F. Liu, E. Ilan, D. Ronen, S. Boura-Halfon, and Y. Zick. (2007). Common inhibitory serine sites phosphorylated by IRS-1 kinases, triggered by insulin and inducers of insulin resistance. J Biol Chem 282 (25):18018-27.

Hirokawa, N., T. Funakoshi, R. Sato-Harada, and Y. Kanai. (1996). Selective stabilization of tau in axons and microtubule-associated protein $2 \mathrm{C}$ in cell bodies and dendrites contributes to polarized localization of cytoskeletal proteins in mature neurons. J Cell Biol 132 (4):667-79.

Ho, L., W. Qin, P. N. Pompl, Z. Xiang, J. Wang, Z. Zhao, Y. Peng, G. Cambareri, A. Rocher, C. V. Mobbs, P. R. Hof, and G. M. Pasinetti. (2004). Diet-induced insulin resistance promotes amyloidosis in a transgenic mouse model of Alzheimer's disease. FASEB J 18 (7):902-4.

Hoeflich, A., R. Reisinger, B. S. Schuett, M. W. Elmlinger, V. C. Russo, G. A. Vargas, P. M. Jehle, H. Lahm, I. Renner-Muller, and E. Wolf. (2004). Peri/nuclear localization of intact insulin-like growth factor binding protein-2 and a distinct carboxyl-terminal IGFBP-2 fragment in vivo. Biochem Biophys Res Commun 324 (2):705-10. 
Hoekman, M. F., F. M. Jacobs, M. P. Smidt, and J. P. Burbach. (2006). Spatial and temporal expression of FoxO transcription factors in the developing and adult murine brain. Gene Expr Patterns 6 (2):134-40.

Holzenberger, M., J. Dupont, B. Ducos, P. Leneuve, A. Geloen, P. C. Even, P. Cervera, and Y. Le Bouc. (2003). IGF-1 receptor regulates lifespan and resistance to oxidative stress in mice. Nature 421 (6919):182-7.

Holzenberger, M., G. Hamard, R. Zaoui, P. Leneuve, B. Ducos, C. Beccavin, L. Perin, and Y. Le Bouc. (2001). Experimental IGF-I receptor deficiency generates a sexually dimorphic pattern of organ-specific growth deficits in mice, affecting fat tissue in particular. Endocrinology 142 (10):4469-78.

Hresko, R. C., H. Murata, and M. Mueckler. (2003). Phosphoinositide-dependent kinase-2 is a distinct protein kinase enriched in a novel cytoskeletal fraction associated with adipocyte plasma membranes. J Biol Chem 278 (24):21615-22.

Hsu, A. L., C. T. Murphy, and C. Kenyon. (2003). Regulation of aging and age-related disease by DAF-16 and heat-shock factor. Science 300 (5622):1142-5.

Huang, H., K. M. Regan, F. Wang, D. Wang, D. I. Smith, J. M. van Deursen, and D. J. Tindall. (2005). Skp2 inhibits FOXO1 in tumor suppression through ubiquitin-mediated degradation. Proc Natl Acad Sci U S A 102 (5):1649-54.

Huang, H., and D. J. Tindall. (2007). Dynamic FoxO transcription factors. J Cell Sci 120 (Pt 15):2479-87.

Hunter, W. S., W. B. Croson, A. Bartke, M. V. Gentry, and C. J. Meliska. (1999). Low body temperature in long-lived Ames dwarf mice at rest and during stress. Physiol Behav 67 (3):433-7.

Hwangbo, D. S., B. Gershman, M. P. Tu, M. Palmer, and M. Tatar. (2004). Drosophila dFOXO controls lifespan and regulates insulin signalling in brain and fat body. Nature 429 (6991):562-6.

Ikeno, Y., R. T. Bronson, G. B. Hubbard, S. Lee, and A. Bartke. (2003). Delayed occurrence of fatal neoplastic diseases in ames dwarf mice: correlation to extended longevity. $J$ Gerontol A Biol Sci Med Sci 58 (4):291-6.

Ikeya, T., M. Galic, P. Belawat, K. Nairz, and E. Hafen. (2002). Nutrient-dependent expression of insulin-like peptides from neuroendocrine cells in the CNS contributes to growth regulation in Drosophila. Curr Biol 12 (15):1293-300.

Iser, W. B., M. S. Gami, and C. A. Wolkow. (2007). Insulin signaling in Caenorhabditis elegans regulates both endocrine-like and cell-autonomous outputs. Dev Biol 303 (2):434-47.

Isgaard, J., L. Carlsson, O. G. Isaksson, and J. O. Jansson. (1988). Pulsatile intravenous growth hormone $(\mathrm{GH})$ infusion to hypophysectomized rats increases insulin-like growth factor I messenger ribonucleic acid in skeletal tissues more effectively than continuous GH infusion. Endocrinology 123 (6):2605-10.

Ittner, L. M., Y. D. Ke, F. Delerue, M. Bi, A. Gladbach, J. van Eersel, H. Wolfing, B. C. Chieng, M. J. Christie, I. A. Napier, A. Eckert, M. Staufenbiel, E. Hardeman, and J. Gotz. (2010). Dendritic function of tau mediates amyloid-beta toxicity in Alzheimer's disease mouse models. Cell 142 (3):387-97.

Iwatsubo, T., A. Odaka, N. Suzuki, H. Mizusawa, N. Nukina, and Y. Ihara. (1994). Visualization of A beta 42(43) and A beta 40 in senile plaques with end-specific A beta monoclonals: evidence that an initially deposited species is A beta 42(43). Neuron 13 (1):45-53. 
Jacobs, F. M., L. P. van der Heide, P. J. Wijchers, J. P. Burbach, M. F. Hoekman, and M. P. Smidt. (2003). FoxO6, a novel member of the FoxO class of transcription factors with distinct shuttling dynamics. J Biol Chem 278 (38):35959-67.

Jacobs, S., F. C. Kull, Jr., H. S. Earp, M. E. Svoboda, J. J. Van Wyk, and P. Cuatrecasas. (1983). Somatomedin-C stimulates the phosphorylation of the beta-subunit of its own receptor. J Biol Chem 258 (16):9581-4.

Jaffe, C. A., B. Ocampo-Lim, W. Guo, K. Krueger, I. Sugahara, R. DeMott-Friberg, M. Bermann, and A. L. Barkan. (1998). Regulatory mechanisms of growth hormone secretion are sexually dimorphic. J Clin Invest 102 (1):153-64.

Jan, Y. N., and L. Y. Jan. (2003). The control of dendrite development. Neuron 40 (2):229-42.

Janson, J., T. Laedtke, J. E. Parisi, P. O'Brien, R. C. Petersen, and P. C. Butler. (2004). Increased risk of type 2 diabetes in Alzheimer disease. Diabetes 53 (2):474-81.

Jansson, J. O., S. Eden, and O. Isaksson. (1985). Sexual dimorphism in the control of growth hormone secretion. Endocr Rev 6 (2):128-50.

Jessup, S. K., E. V. Dimaraki, K. V. Symons, and A. L. Barkan. (2003). Sexual dimorphism of growth hormone $(\mathrm{GH})$ regulation in humans: endogenous $\mathrm{GH}$-releasing hormone maintains basal GH in women but not in men. J Clin Endocrinol Metab 88 (10):4776-80.

Jin, M. H., Y. H. Lee, J. M. Kim, H. N. Sun, E. Y. Moon, M. H. Shong, S. U. Kim, S. H. Lee, T. H. Lee, D. Y. Yu, and D. S. Lee. (2005). Characterization of neural cell types expressing peroxiredoxins in mouse brain. Neurosci Lett 381 (3):252-7.

Jones, J. I., and D. R. Clemmons. (1995). Insulin-like growth factors and their binding proteins: biological actions. Endocr Rev 16 (1):3-34.

Junger, M. A., F. Rintelen, H. Stocker, J. D. Wasserman, M. Vegh, T. Radimerski, M. E. Greenberg, and E. Hafen. (2003). The Drosophila forkhead transcription factor FOXO mediates the reduction in cell number associated with reduced insulin signaling. $J$ Biol 2 (3):20.

Kang, J., H. G. Lemaire, A. Unterbeck, J. M. Salbaum, C. L. Masters, K. H. Grzeschik, G. Multhaup, K. Beyreuther, and B. Muller-Hill. (1987). The precursor of Alzheimer's disease amyloid A4 protein resembles a cell-surface receptor. Nature 325 (6106):733-6.

Kang, J., and B. Muller-Hill. (1990). Differential splicing of Alzheimer's disease amyloid A4 precursor RNA in rat tissues: PreA4(695) mRNA is predominantly produced in rat and human brain. Biochem Biophys Res Commun 166 (3):1192-200.

Kappeler, L., C. De Magalhaes Filho, J. Dupont, P. Leneuve, P. Cervera, L. Perin, C. Loudes, A. Blaise, R. Klein, J. Epelbaum, Y. Le Bouc, and M. Holzenberger. (2008). Brain IGF-1 receptors control mammalian growth and lifespan through a neuroendocrine mechanism. PLoS Biol 6 (10):e254.

Kasuga, M., F. A. Karlsson, and C. R. Kahn. (1982). Insulin stimulates the phosphorylation of the 95,000-dalton subunit of its own receptor. Science 215 (4529):185-7.

Kasuga, M., Y. Zick, D. L. Blithe, M. Crettaz, and C. R. Kahn. (1982). Insulin stimulates tyrosine phosphorylation of the insulin receptor in a cell-free system. Nature 298 (5875):667-9.

Kelley, K. M., Y. Oh, S. E. Gargosky, Z. Gucev, T. Matsumoto, V. Hwa, L. Ng, D. M. Simpson, and R. G. Rosenfeld. (1996). Insulin-like growth factor-binding proteins (IGFBPs) and their regulatory dynamics. Int J Biochem Cell Biol 28 (6):619-37.

Kenyon, C. (2005). The plasticity of aging: insights from long-lived mutants. Cell 120 (4):449-60.

Kenyon, C., J. Chang, E. Gensch, A. Rudner, and R. Tabtiang. (1993). A C. elegans mutant that lives twice as long as wild type. Nature 366 (6454):461-4. 
Kenyon, C. J. (2010). The genetics of ageing. Nature 464 (7288):504-12.

Khan, A. S., C. D. Lynch, D. C. Sane, M. C. Willingham, and W. E. Sonntag. (2001). Growth hormone increases regional coronary blood flow and capillary density in aged rats. $J$ Gerontol A Biol Sci Med Sci 56 (8):B364-71.

Kheterpal, I., H. A. Lashuel, D. M. Hartley, T. Walz, P. T. Lansbury, Jr., and R. Wetzel. (2003). Abeta protofibrils possess a stable core structure resistant to hydrogen exchange. Biochemistry 42 (48):14092-8.

Kiess, W., Y. Yang, U. Kessler, and A. Hoeflich. (1994). Insulin-like growth factor II (IGF-II) and the IGF-II/mannose-6-phosphate receptor: the myth continues. Horm Res 41 Suppl 2:66-73.

Killick, R., G. Scales, K. Leroy, M. Causevic, C. Hooper, E. E. Irvine, A. I. Choudhury, L. Drinkwater, F. Kerr, H. Al-Qassab, J. Stephenson, Z. Yilmaz, K. P. Giese, J. P. Brion, D. J. Withers, and S. Lovestone. (2009). Deletion of Irs2 reduces amyloid deposition and rescues behavioural deficits in APP transgenic mice. Biochem Biophys Res Commun 386 (1):257-62.

Kim, H. S., S. R. Nagalla, Y. Oh, E. Wilson, C. T. Roberts, Jr., and R. G. Rosenfeld. (1997). Identification of a family of low-affinity insulin-like growth factor binding proteins (IGFBPs): characterization of connective tissue growth factor as a member of the IGFBP superfamily. Proc Natl Acad Sci U S A 94 (24):12981-6.

Kinney, B. A., K. T. Coschigano, J. J. Kopchick, R. W. Steger, and A. Bartke. (2001). Evidence that age-induced decline in memory retention is delayed in growth hormone resistant GH-R-KO (Laron) mice. Physiol Behav 72 (5):653-60.

Kitamura, Y. I., T. Kitamura, J. P. Kruse, J. C. Raum, R. Stein, W. Gu, and D. Accili. (2005). FoxO1 protects against pancreatic beta cell failure through NeuroD and MafA induction. Cell Metab 2 (3):153-63.

Klein, W. L., W. B. Stine, Jr., and D. B. Teplow. (2004). Small assemblies of unmodified amyloid beta-protein are the proximate neurotoxin in Alzheimer's disease. Neurobiol Aging 25 (5):569-80.

Kops, G. J., T. B. Dansen, P. E. Polderman, I. Saarloos, K. W. Wirtz, P. J. Coffer, T. T. Huang, J. L. Bos, R. H. Medema, and B. M. Burgering. (2002). Forkhead transcription factor FOXO3a protects quiescent cells from oxidative stress. Nature 419 (6904):316-21.

Kops, G. J., N. D. de Ruiter, A. M. De Vries-Smits, D. R. Powell, J. L. Bos, and B. M. Burgering. (1999). Direct control of the Forkhead transcription factor AFX by protein kinase B. Nature 398 (6728):630-4.

Kuningas, M., R. Magi, R. G. Westendorp, P. E. Slagboom, M. Remm, and D. van Heemst. (2007). Haplotypes in the human Foxo1a and Foxo3a genes; impact on disease and mortality at old age. Eur J Hum Genet 15 (3):294-301.

Lambert, M. P., A. K. Barlow, B. A. Chromy, C. Edwards, R. Freed, M. Liosatos, T. E. Morgan, I. Rozovsky, B. Trommer, K. L. Viola, P. Wals, C. Zhang, C. E. Finch, G. A. Krafft, and W. L. Klein. (1998). Diffusible, nonfibrillar ligands derived from Abeta1-42 are potent central nervous system neurotoxins. Proc Natl Acad Sci U S A 95 (11):6448-53.

Lanz, T. A., C. T. Salatto, A. R. Semproni, M. Marconi, T. M. Brown, K. E. Richter, K. Schmidt, F. R. Nelson, and J. B. Schachter. (2008). Peripheral elevation of IGF-1 fails to alter Abeta clearance in multiple in vivo models. Biochem Pharmacol 75 (5):1093-103. 
Lavan, B. E., V. R. Fantin, E. T. Chang, W. S. Lane, S. R. Keller, and G. E. Lienhard. (1997). A novel $160-\mathrm{kDa}$ phosphotyrosine protein in insulin-treated embryonic kidney cells is a new member of the insulin receptor substrate family. J Biol Chem 272 (34):21403-7.

Lavan, B. E., W. S. Lane, and G. E. Lienhard. (1997). The 60-kDa phosphotyrosine protein in insulin-treated adipocytes is a new member of the insulin receptor substrate family. $J$ Biol Chem 272 (17):11439-43.

Lawlor, M. A., and D. R. Alessi. (2001). PKB/Akt: a key mediator of cell proliferation, survival and insulin responses? J Cell Sci 114 (Pt 16):2903-10.

Lawrence, J. B., C. Oxvig, M. T. Overgaard, L. Sottrup-Jensen, G. J. Gleich, L. G. Hays, J. R. Yates, 3rd, and C. A. Conover. (1999). The insulin-like growth factor (IGF)-dependent IGF binding protein-4 protease secreted by human fibroblasts is pregnancyassociated plasma protein-A. Proc Natl Acad Sci U S A 96 (6):3149-53.

Lee, K. S., K. Iijima-Ando, K. Iijima, W. J. Lee, J. H. Lee, K. Yu, and D. S. Lee. (2009). JNK/FOXO-mediated neuronal expression of fly homologue of peroxiredoxin II reduces oxidative stress and extends life span. J Biol Chem 284 (43):29454-61.

LeRoith, D. (2000). Insulin-like growth factor I receptor signaling--overlapping or redundant pathways? Endocrinology 141 (4):1287-8.

Lesne, S., M. T. Koh, L. Kotilinek, R. Kayed, C. G. Glabe, A. Yang, M. Gallagher, and K. H. Ashe. (2006). A specific amyloid-beta protein assembly in the brain impairs memory. Nature 440 (7082):352-7.

Leung, K. C., G. Johannsson, G. M. Leong, and K. K. Ho. (2004). Estrogen regulation of growth hormone action. Endocr Rev 25 (5):693-721.

LeVine, H., 3rd. (1999). Quantification of beta-sheet amyloid fibril structures with thioflavin T. Methods Enzymol 309:274-84.

Li, M., J. Luo, C. L. Brooks, and W. Gu. (2002). Acetylation of p53 inhibits its ubiquitination by Mdm2. J Biol Chem 277 (52):50607-11.

Li, W., S. G. Kennedy, and G. Ruvkun. (2003). daf-28 encodes a C. elegans insulin superfamily member that is regulated by environmental cues and acts in the DAF-2 signaling pathway. Genes Dev 17 (7):844-58.

Li, Y., Y. He, L. Qi, V. W. Jaddoe, E. J. Feskens, X. Yang, G. Ma, and F. B. Hu. (2010). Exposure to the Chinese famine in early life and the risk of hyperglycemia and type 2 diabetes in adulthood. Diabetes 59 (10):2400-6.

Li, Y., V. W. Jaddoe, L. Qi, Y. He, D. Wang, J. Lai, J. Zhang, P. Fu, X. Yang, and F. B. Hu. (2011). Exposure to the Chinese Famine in Early Life and the Risk of Metabolic Syndrome in Adulthood. Diabetes Care.

Li, Y., W. J. Wang, H. Cao, J. Lu, C. Wu, F. Y. Hu, J. Guo, L. Zhao, F. Yang, Y. X. Zhang, W. Li, G. Y. Zheng, H. Cui, X. Chen, Z. Zhu, H. He, B. Dong, X. Mo, Y. Zeng, and X. L. Tian. (2009). Genetic association of FOXO1A and FOXO3A with longevity trait in Han Chinese populations. Hum Mol Genet 18 (24):4897-904.

Liang, H., E. J. Masoro, J. F. Nelson, R. Strong, C. A. McMahan, and A. Richardson. (2003). Genetic mouse models of extended lifespan. Exp Gerontol 38 (11-12):1353-64.

Lim, Y. S., M. K. Cha, H. K. Kim, T. B. Uhm, J. W. Park, K. Kim, and I. H. Kim. (1993). Removals of hydrogen peroxide and hydroxyl radical by thiol-specific antioxidant protein as a possible role in vivo. Biochem Biophys Res Commun 192 (1):273-80. 
Lin, K., J. B. Dorman, A. Rodan, and C. Kenyon. (1997). daf-16: An HNF-3/forkhead family member that can function to double the life-span of Caenorhabditis elegans. Science 278 (5341):1319-22.

Lin, M. T., and M. F. Beal. (2006). Mitochondrial dysfunction and oxidative stress in neurodegenerative diseases. Nature 443 (7113):787-95.

Lindeboom, M., F. Portrait, and G. J. van den Berg. (2010). Long-run effects on longevity of a nutritional shock early in life: the Dutch Potato famine of 1846-1847. J Health Econ 29 (5):617-29.

Liu, J. P., J. Baker, A. S. Perkins, E. J. Robertson, and A. Efstratiadis. (1993). Mice carrying null mutations of the genes encoding insulin-like growth factor I (Igf-1) and type 1 IGF receptor (Igf1r). Cell 75 (1):59-72.

Liu, R., X. W. Zhou, H. Tanila, C. Bjorkdahl, J. Z. Wang, Z. Z. Guan, Y. Cao, J. A. Gustafsson, B. Winblad, and J. J. Pei. (2008). Phosphorylated PP2A (tyrosine 307) is associated with Alzheimer neurofibrillary pathology. J Cell Mol Med 12 (1):241-57.

Lopez-Lopez, C., D. LeRoith, and I. Torres-Aleman. (2004). Insulin-like growth factor I is required for vessel remodeling in the adult brain. Proc Natl Acad Sci U S A 101 (26):9833-8.

Louvi, A., D. Accili, and A. Efstratiadis. (1997). Growth-promoting interaction of IGF-II with the insulin receptor during mouse embryonic development. Dev Biol 189 (1):33-48.

Luchsinger, J. A., M. X. Tang, S. Shea, and R. Mayeux. (2004). Hyperinsulinemia and risk of Alzheimer disease. Neurology 63 (7):1187-92.

Luo, M., P. Langlais, Z. Yi, N. Lefort, E. A. De Filippis, H. Hwang, C. Y. Christ-Roberts, and L. J. Mandarino. (2007). Phosphorylation of human insulin receptor substrate-1 at Serine 629 plays a positive role in insulin signaling. Endocrinology 148 (10):4895-905.

Luo, M., S. Reyna, L. Wang, Z. Yi, C. Carroll, L. Q. Dong, P. Langlais, S. T. Weintraub, and L. J. Mandarino. (2005). Identification of insulin receptor substrate 1 serine/threonine phosphorylation sites using mass spectrometry analysis: regulatory role of serine 1223. Endocrinology 146 (10):4410-6.

Luo, Z. C., W. D. Fraser, P. Julien, C. L. Deal, F. Audibert, G. N. Smith, X. Xiong, and M. Walker. (2006). Tracing the origins of "fetal origins" of adult diseases: programming by oxidative stress? Med Hypotheses 66 (1):38-44.

Maile, L. A., and J. M. Holly. (1999). Insulin-like growth factor binding protein (IGFBP) proteolysis: occurrence, identification, role and regulation. Growth Horm IGF Res 9 (2):85-95.

Major, J. M., G. A. Laughlin, D. Kritz-Silverstein, D. L. Wingard, and E. Barrett-Connor. (2010). Insulin-like growth factor-I and cancer mortality in older men. J Clin Endocrinol Metab 95 (3):1054-9.

Marks, J. L., D. Porte, Jr., and D. G. Baskin. (1991). Localization of type I insulin-like growth factor receptor messenger RNA in the adult rat brain by in situ hybridization. Mol Endocrinol 5 (8):1158-68.

Masters, C. L., G. Simms, N. A. Weinman, G. Multhaup, B. L. McDonald, and K. Beyreuther. (1985). Amyloid plaque core protein in Alzheimer disease and Down syndrome. Proc Natl Acad Sci U S A 82 (12):4245-9.

Matsuo, K., M. Niwa, M. Kurihara, K. Shigematsu, S. Yamashita, M. Ozaki, and S. Nagataki. (1989). Receptor autoradiographic analysis of insulin-like growth factor-I (IGF-I) binding sites in rat forebrain and pituitary gland. Cell Mol Neurobiol 9 (3):357-67. 
Matthieu, J. M., S. Widmer, and N. Herschkowitz. (1973). Biochemical changes in mouse brain composition during myelination. Brain Res 55 (2):391-402.

McClain, D. A. (1991). Different ligand affinities of the two human insulin receptor splice variants are reflected in parallel changes in sensitivity for insulin action. Mol Endocrinol 5 (5):734-9.

McLean, C. A., R. A. Cherny, F. W. Fraser, S. J. Fuller, M. J. Smith, K. Beyreuther, A. I. Bush, and C. L. Masters. (1999). Soluble pool of Abeta amyloid as a determinant of severity of neurodegeneration in Alzheimer's disease. Ann Neurol 46 (6):860-6.

McMorris, F. A., and M. Dubois-Dalcq. (1988). Insulin-like growth factor I promotes cell proliferation and oligodendroglial commitment in rat glial progenitor cells developing in vitro. J Neurosci Res 21 (2-4):199-209.

McMorris, F. A., T. M. Smith, S. DeSalvo, and R. W. Furlanetto. (1986). Insulin-like growth factor I/somatomedin C: a potent inducer of oligodendrocyte development. Proc Natl Acad Sci U S A 83 (3):822-6.

Medema, R. H., G. J. Kops, J. L. Bos, and B. M. Burgering. (2000). AFX-like Forkhead transcription factors mediate cell-cycle regulation by Ras and PKB through p27kip1. Nature 404 (6779):782-7.

Michaluk, P., and L. Kaczmarek. (2007). Matrix metalloproteinase-9 in glutamate-dependent adult brain function and dysfunction. Cell Death Differ 14 (7):1255-8.

Miller, R. A., J. M. Harper, A. Galecki, and D. T. Burke. (2002). Big mice die young: early life body weight predicts longevity in genetically heterogeneous mice. Aging Cell 1 (1):229.

Millward, T. A., S. Zolnierowicz, and B. A. Hemmings. (1999). Regulation of protein kinase cascades by protein phosphatase 2A. Trends Biochem Sci 24 (5):186-91.

Mohan, S., and D. J. Baylink. (2002). IGF-binding proteins are multifunctional and act via IGFdependent and -independent mechanisms. J Endocrinol 175 (1):19-31.

Mohseni-Zadeh, S., and M. Binoux. (1997). Insulin-like growth factor (IGF) binding protein-3 interacts with the type 1 IGF receptor, reducing the affinity of the receptor for its ligand: an alternative mechanism in the regulation of IGF action. Endocrinology 138 (12):5645-8.

Moller, D. E., A. Yokota, J. F. Caro, and J. S. Flier. (1989). Tissue-specific expression of two alternatively spliced insulin receptor mRNAs in man. Mol Endocrinol 3 (8):1263-9.

Moloney, A. M., R. J. Griffin, S. Timmons, R. O'Connor, R. Ravid, and C. O'Neill. (2010). Defects in IGF-1 receptor, insulin receptor and IRS-1/2 in Alzheimer's disease indicate possible resistance to IGF-1 and insulin signalling. Neurobiol Aging 31 (2):22443.

Morell, P., S. Greenfield, E. Costantino-Ceccarini, and H. Wisniewski. (1972). Changes in the protein composition of mouse brain myelin during development. J Neurochem 19 (11):2545-54.

Morgan, D. O., J. C. Edman, D. N. Standring, V. A. Fried, M. C. Smith, R. A. Roth, and W. J. Rutter. (1987). Insulin-like growth factor II receptor as a multifunctional binding protein. Nature 329 (6137):301-7.

Morris, J. Z., H. A. Tissenbaum, and G. Ruvkun. (1996). A phosphatidylinositol-3-OH kinase family member regulating longevity and diapause in Caenorhabditis elegans. Nature 382 (6591):536-9. 
Moxham, C. P., V. Duronio, and S. Jacobs. (1989). Insulin-like growth factor I receptor betasubunit heterogeneity. Evidence for hybrid tetramers composed of insulin-like growth factor I and insulin receptor heterodimers. J Biol Chem 264 (22):13238-44.

Mozell, R. L., and F. A. McMorris. (1991). Insulin-like growth factor I stimulates oligodendrocyte development and myelination in rat brain aggregate cultures. $J$ Neurosci Res 30 (2):382-90.

Muller-Hill, B., and K. Beyreuther. (1989). Molecular biology of Alzheimer's disease. Annu Rev Biochem 58:287-307.

Mullis, P. E. (2005). Genetic control of growth. Eur J Endocrinol 152 (1):11-31.

Murakami, S. (2007). Caenorhabditis elegans as a model system to study aging of learning and memory. Mol Neurobiol 35 (1):85-94.

Murakami, S., A. Salmon, and R. A. Miller. (2003). Multiplex stress resistance in cells from long-lived dwarf mice. FASEB J 17 (11):1565-6.

Nakagawa, T., H. Zhu, N. Morishima, E. Li, J. Xu, B. A. Yankner, and J. Yuan. (2000). Caspase12 mediates endoplasmic-reticulum-specific apoptosis and cytotoxicity by amyloidbeta. Nature 403 (6765):98-103.

Nikolic, M. (2008). The Pak1 kinase: an important regulator of neuronal morphology and function in the developing forebrain. Mol Neurobiol 37 (2-3):187-202.

Nishijima, T., J. Piriz, S. Duflot, A. M. Fernandez, G. Gaitan, U. Gomez-Pinedo, J. M. Verdugo, F. Leroy, H. Soya, A. Nunez, and I. Torres-Aleman. (2010). Neuronal activity drives localized blood-brain-barrier transport of serum insulin-like growth factor-I into the CNS. Neuron 67 (5):834-46.

Nojima, H., C. Tokunaga, S. Eguchi, N. Oshiro, S. Hidayat, K. Yoshino, K. Hara, N. Tanaka, J. Avruch, and K. Yonezawa. (2003). The mammalian target of rapamycin (mTOR) partner, raptor, binds the mTOR substrates p70 S6 kinase and 4E-BP1 through their TOR signaling (TOS) motif. J Biol Chem 278 (18):15461-4.

Ogasawara, M., K. P. Karey, H. Marquardt, and D. A. Sirbasku. (1989). Identification and purification of truncated insulin-like growth factor I from porcine uterus. Evidence for high biological potency. Biochemistry 28 (6):2710-21.

Ogg, S., S. Paradis, S. Gottlieb, G. I. Patterson, L. Lee, H. A. Tissenbaum, and G. Ruvkun. (1997). The Fork head transcription factor DAF-16 transduces insulin-like metabolic and longevity signals in C. elegans. Nature 389 (6654):994-9.

Oh, Y., M. W. Beukers, H. M. Pham, P. A. Smanik, M. C. Smith, and R. G. Rosenfeld. (1991). Altered affinity of insulin-like growth factor II (IGF-II) for receptors and IGF-binding proteins, resulting from limited modifications of the IGF-II molecule. Biochem J 278 ( Pt 1):249-54.

Oh, Y., H. L. Muller, G. Lamson, and R. G. Rosenfeld. (1993). Insulin-like growth factor (IGF)independent action of IGF-binding protein-3 in Hs578T human breast cancer cells. Cell surface binding and growth inhibition. J Biol Chem 268 (20):14964-71.

Ohlsson, C., S. Mohan, K. Sjogren, A. Tivesten, J. Isgaard, O. Isaksson, J. O. Jansson, and J. Svensson. (2009). The role of liver-derived insulin-like growth factor-I. Endocr Rev 30 (5):494-535.

Orme, S. M., R. J. McNally, R. A. Cartwright, and P. E. Belchetz. (1998). Mortality and cancer incidence in acromegaly: a retrospective cohort study. United Kingdom Acromegaly Study Group. J Clin Endocrinol Metab 83 (8):2730-4. 
Oshiro, N., K. Yoshino, S. Hidayat, C. Tokunaga, K. Hara, S. Eguchi, J. Avruch, and K. Yonezawa. (2004). Dissociation of raptor from mTOR is a mechanism of rapamycininduced inhibition of mTOR function. Genes Cells 9 (4):359-66.

Ott, A., R. P. Stolk, A. Hofman, F. van Harskamp, D. E. Grobbee, and M. M. Breteler. (1996). Association of diabetes mellitus and dementia: the Rotterdam Study. Diabetologia 39 (11):1392-7.

Ott, A., R. P. Stolk, F. van Harskamp, H. A. Pols, A. Hofman, and M. M. Breteler. (1999). Diabetes mellitus and the risk of dementia: The Rotterdam Study. Neurology 53 (9):1937-42.

Ott, A., C. T. van Rossum, F. van Harskamp, H. van de Mheen, A. Hofman, and M. M. Breteler. (1999). Education and the incidence of dementia in a large population-based study: the Rotterdam Study. Neurology 52 (3):663-6.

P, E. Mullis. (2010). Genetics of isolated growth hormone deficiency. J Clin Res Pediatr Endocrinol 2 (2):52-62.

Painter, R. C., T. J. Roseboom, and O. P. Bleker. (2005). Prenatal exposure to the Dutch famine and disease in later life: an overview. Reprod Toxicol 20 (3):345-52.

Pan, W., and A. J. Kastin. (2000). Interactions of IGF-1 with the blood-brain barrier in vivo and in situ. Neuroendocrinology 72 (3):171-8.

Pandini, G., F. Frasca, R. Mineo, L. Sciacca, R. Vigneri, and A. Belfiore. (2002). Insulin/insulinlike growth factor I hybrid receptors have different biological characteristics depending on the insulin receptor isoform involved. J Biol Chem 277 (42):39684-95.

Paradis, S., and G. Ruvkun. (1998). Caenorhabditis elegans Akt/PKB transduces insulin receptor-like signals from AGE-1 PI3 kinase to the DAF-16 transcription factor. Genes Dev 12 (16):2488-98.

Partridge, L., and J. C. Bruning. (2008). Forkhead transcription factors and ageing. Oncogene 27 (16):2351-63.

Pawlikowska, L., D. Hu, S. Huntsman, A. Sung, C. Chu, J. Chen, A. H. Joyner, N. J. Schork, W. C. Hsueh, A. P. Reiner, B. M. Psaty, G. Atzmon, N. Barzilai, S. R. Cummings, W. S. Browner, P. Y. Kwok, and E. Ziv. (2009). Association of common genetic variation in the insulin/IGF1 signaling pathway with human longevity. Aging Cell 8 (4):460-72.

Pierce, S. B., M. Costa, R. Wisotzkey, S. Devadhar, S. A. Homburger, A. R. Buchman, K. C. Ferguson, J. Heller, D. M. Platt, A. A. Pasquinelli, L. X. Liu, S. K. Doberstein, and G. Ruvkun. (2001). Regulation of DAF-2 receptor signaling by human insulin and ins-1, a member of the unusually large and diverse $\mathrm{C}$. elegans insulin gene family. Genes Dev 15 (6):672-86.

Pilcher, H. (2006). Alzheimer's disease could be "type 3 diabetes". Lancet Neurol 5 (5):388-9.

Piper, M. D., C. Selman, J. J. McElwee, and L. Partridge. (2008). Separating cause from effect: how does insulin/IGF signalling control lifespan in worms, flies and mice? J Intern Med 263 (2):179-91.

Pollak, M. N., E. S. Schernhammer, and S. E. Hankinson. (2004). Insulin-like growth factors and neoplasia. Nat Rev Cancer 4 (7):505-18.

Polleux, F., G. Ince-Dunn, and A. Ghosh. (2007). Transcriptional regulation of vertebrate axon guidance and synapse formation. Nat Rev Neurosci 8 (5):331-40.

Poretsky, L., N. A. Cataldo, Z. Rosenwaks, and L. C. Giudice. (1999). The insulin-related ovarian regulatory system in health and disease. Endocr Rev 20 (4):535-82. 
Puglielli, L. (2008). Aging of the brain, neurotrophin signaling, and Alzheimer's disease: is IGF1-R the common culprit? Neurobiol Aging 29 (6):795-811.

Puglielli, L., B. C. Ellis, A. J. Saunders, and D. M. Kovacs. (2003). Ceramide stabilizes beta-site amyloid precursor protein-cleaving enzyme 1 and promotes amyloid beta-peptide biogenesis. J Biol Chem 278 (22):19777-83.

Puig, O., M. T. Marr, M. L. Ruhf, and R. Tjian. (2003). Control of cell number by Drosophila FOXO: downstream and feedback regulation of the insulin receptor pathway. Genes Dev 17 (16):2006-20.

Qin, X., D. D. Strong, D. J. Baylink, and S. Mohan. (1998). Structure-function analysis of the human insulin-like growth factor binding protein-4. J Biol Chem 273 (36):23509-16.

Radulescu, R. T. (1994). Nuclear localization signal in insulin-like growth factor-binding protein type 3. Trends Biochem Sci 19 (7):278.

Rajah, R., L. Katz, S. Nunn, P. Solberg, T. Beers, and P. Cohen. (1995). Insulin-like growth factor binding protein (IGFBP) proteases: functional regulators of cell growth. Prog Growth Factor Res 6 (2-4):273-84.

Rajaram, S., D. J. Baylink, and S. Mohan. (1997). Insulin-like growth factor-binding proteins in serum and other biological fluids: regulation and functions. Endocr Rev 18 (6):801-31.

Ravelli, A. C., J. H. van der Meulen, R. P. Michels, C. Osmond, D. J. Barker, C. N. Hales, and O. P. Bleker. (1998). Glucose tolerance in adults after prenatal exposure to famine. Lancet 351 (9097):173-7.

Ravelli, A. C., J. H. van Der Meulen, C. Osmond, D. J. Barker, and O. P. Bleker. (1999). Obesity at the age of $50 \mathrm{y}$ in men and women exposed to famine prenatally. Am J Clin Nutr 70 (5):811-6.

Rechler, M. M. (1993). Insulin-like growth factor binding proteins. Vitam Horm 47:1-114.

Rechler, M. M., and D. R. Clemmons. (1998). Regulatory Actions of Insulin-like Growth Factorbinding Proteins. Trends Endocrinol Metab 9 (5):176-83.

Rena, G., S. Guo, S. C. Cichy, T. G. Unterman, and P. Cohen. (1999). Phosphorylation of the transcription factor forkhead family member FKHR by protein kinase B. J Biol Chem $274(24): 17179-83$.

Renault, V. M., V. A. Rafalski, A. A. Morgan, D. A. Salih, J. O. Brett, A. E. Webb, S. A. Villeda, P. U. Thekkat, C. Guillerey, N. C. Denko, T. D. Palmer, A. J. Butte, and A. Brunet. (2009). FoxO3 regulates neural stem cell homeostasis. Cell Stem Cell 5 (5):527-39.

Resch, Z. T., R. D. Simari, and C. A. Conover. (2006). Targeted disruption of the pregnancyassociated plasma protein-A gene is associated with diminished smooth muscle cell response to insulin-like growth factor-I and resistance to neointimal hyperplasia after vascular injury. Endocrinology 147 (12):5634-40.

Rincon, M., E. Rudin, and N. Barzilai. (2005). The insulin/IGF-1 signaling in mammals and its relevance to human longevity. Exp Gerontol 40 (11):873-7.

Rivera, E. J., A. Goldin, N. Fulmer, R. Tavares, J. R. Wands, and S. M. de la Monte. (2005). Insulin and insulin-like growth factor expression and function deteriorate with progression of Alzheimer's disease: link to brain reductions in acetylcholine. $J$ Alzheimers Dis 8 (3):247-68.

Robakis, N. K., H. M. Wisniewski, E. C. Jenkins, E. A. Devine-Gage, G. E. Houck, X. L. Yao, N. Ramakrishna, G. Wolfe, W. P. Silverman, and W. T. Brown. (1987). Chromosome 21q21 sublocalisation of gene encoding beta-amyloid peptide in cerebral vessels and 
neuritic (senile) plaques of people with Alzheimer disease and Down syndrome. Lancet 1 (8529):384-5.

Roberson, E. D., and L. Mucke. (2006). 100 years and counting: prospects for defeating Alzheimer's disease. Science 314 (5800):781-4.

Robertson, J., T. L. Loviny, M. Goedert, R. Jakes, K. J. Murray, B. H. Anderton, and D. P. Hanger. (1993). Phosphorylation of tau by cyclic-AMP-dependent protein kinase. Dementia 4 (5):256-63.

Rogaev, E. I., R. Sherrington, E. A. Rogaeva, G. Levesque, M. Ikeda, Y. Liang, H. Chi, C. Lin, K. Holman, T. Tsuda, and et al. (1995). Familial Alzheimer's disease in kindreds with missense mutations in a gene on chromosome 1 related to the Alzheimer's disease type 3 gene. Nature 376 (6543):775-8.

Roher, A. E., M. O. Chaney, Y. M. Kuo, S. D. Webster, W. B. Stine, L. J. Haverkamp, A. S. Woods, R. J. Cotter, J. M. Tuohy, G. A. Krafft, B. S. Bonnell, and M. R. Emmerling. (1996). Morphology and toxicity of Abeta-(1-42) dimer derived from neuritic and vascular amyloid deposits of Alzheimer's disease. J Biol Chem 271 (34):20631-5.

Rollo, C. D. (2002). Growth negatively impacts the life span of mammals. Evol Dev 4 (1):55-61.

Roman, G., K. Endo, L. Zong, and R. L. Davis. (2001). P[Switch], a system for spatial and temporal control of gene expression in Drosophila melanogaster. Proc Natl Acad Sci U $S$ A 98 (22):12602-7.

Romanick, M. A., S. G. Rakoczy, and H. M. Brown-Borg. (2004). Long-lived Ames dwarf mouse exhibits increased antioxidant defense in skeletal muscle. Mech Ageing Dev 125 (4):269-81.

Romero, C. J., Y. Ng, R. M. Luque, R. D. Kineman, L. Koch, J. C. Bruning, and S. Radovick. (2010). Targeted deletion of somatotroph insulin-like growth factor-I signaling in a cell-specific knockout mouse model. Mol Endocrinol 24 (5):1077-89.

Ronnemaa, E., B. Zethelius, J. Sundelof, J. Sundstrom, M. Degerman-Gunnarsson, C. Berne, L. Lannfelt, and L. Kilander. (2008). Impaired insulin secretion increases the risk of Alzheimer disease. Neurology 71 (14):1065-71.

Roseboom, T. J., J. H. van der Meulen, C. Osmond, D. J. Barker, A. C. Ravelli, and O. P. Bleker. (2000). Plasma lipid profiles in adults after prenatal exposure to the Dutch famine. Am J Clin Nutr 72 (5):1101-6.

Roseboom, T. J., J. H. van der Meulen, C. Osmond, D. J. Barker, A. C. Ravelli, J. M. SchroederTanka, G. A. van Montfrans, R. P. Michels, and O. P. Bleker. (2000). Coronary heart disease after prenatal exposure to the Dutch famine, 1944-45. Heart 84 (6):595-8.

Ross, C. A., and M. A. Poirier. (2005). Opinion: What is the role of protein aggregation in neurodegeneration? Nat Rev Mol Cell Biol 6 (11):891-8.

Rotwein, P., S. K. Burgess, J. D. Milbrandt, and J. E. Krause. (1988). Differential expression of insulin-like growth factor genes in rat central nervous system. Proc Natl Acad Sci U S A 85 (1):265-9.

Rovelet-Lecrux, A., D. Hannequin, G. Raux, N. Le Meur, A. Laquerriere, A. Vital, C. Dumanchin, S. Feuillette, A. Brice, M. Vercelletto, F. Dubas, T. Frebourg, and D. Campion. (2006). APP locus duplication causes autosomal dominant early-onset Alzheimer disease with cerebral amyloid angiopathy. Nat Genet 38 (1):24-6.

Rubin, J. B., M. A. Shia, and P. F. Pilch. (1983). Stimulation of tyrosine-specific phosphorylation in vitro by insulin-like growth factor I. Nature 305 (5933):438-40. 
Rubin, R., and R. Baserga. (1995). Insulin-like growth factor-I receptor. Its role in cell proliferation, apoptosis, and tumorigenicity. Lab Invest 73 (3):311-31.

Rudman, D., A. G. Feller, H. S. Nagraj, G. A. Gergans, P. Y. Lalitha, A. F. Goldberg, R. A. Schlenker, L. Cohn, I. W. Rudman, and D. E. Mattson. (1990). Effects of human growth hormone in men over 60 years old. N Engl J Med 323 (1):1-6.

Rudman, D., M. H. Kutner, C. M. Rogers, M. F. Lubin, G. A. Fleming, and R. P. Bain. (1981). Impaired growth hormone secretion in the adult population: relation to age and adiposity. J Clin Invest 67 (5):1361-9.

Russo, V. C., P. D. Gluckman, E. L. Feldman, and G. A. Werther. (2005). The insulin-like growth factor system and its pleiotropic functions in brain. Endocr Rev 26 (7):916-43.

Russo, V. C., B. S. Schutt, E. Andaloro, S. I. Ymer, A. Hoeflich, M. B. Ranke, L. A. Bach, and G. A. Werther. (2005). Insulin-like growth factor binding protein-2 binding to extracellular matrix plays a critical role in neuroblastoma cell proliferation, migration, and invasion. Endocrinology 146 (10):4445-55.

Sakano, K., T. Enjoh, F. Numata, H. Fujiwara, Y. Marumoto, N. Higashihashi, Y. Sato, J. F. Perdue, and Y. Fujita-Yamaguchi. (1991). The design, expression, and characterization of human insulin-like growth factor II (IGF-II) mutants specific for either the IGFII/cation-independent mannose 6-phosphate receptor or IGF-I receptor. J Biol Chem 266 (31):20626-35.

Saltiel, A. R., and C. R. Kahn. (2001). Insulin signalling and the regulation of glucose and lipid metabolism. Nature 414 (6865):799-806.

Sauer, B. (1998). Inducible gene targeting in mice using the Cre/lox system. Methods 14 (4):38192.

Sawka-Verhelle, D., V. Baron, I. Mothe, C. Filloux, M. F. White, and E. Van Obberghen. (1997). Tyr624 and Tyr628 in insulin receptor substrate- 2 mediate its association with the insulin receptor. J Biol Chem 272 (26):16414-20.

Sawka-Verhelle, D., S. Tartare-Deckert, M. F. White, and E. Van Obberghen. (1996). Insulin receptor substrate-2 binds to the insulin receptor through its phosphotyrosinebinding domain and through a newly identified domain comprising amino acids 591786. J Biol Chem 271 (11):5980-3.

Schedlich, L. J., T. F. Young, S. M. Firth, and R. C. Baxter. (1998). Insulin-like growth factorbinding protein (IGFBP)-3 and IGFBP-5 share a common nuclear transport pathway in T47D human breast carcinoma cells. J Biol Chem 273 (29):18347-52.

Schellenberg, G. D., T. D. Bird, E. M. Wijsman, H. T. Orr, L. Anderson, E. Nemens, J. A. White, L. Bonnycastle, J. L. Weber, M. E. Alonso, and et al. (1992). Genetic linkage evidence for a familial Alzheimer's disease locus on chromosome 14. Science 258 (5082):668-71.

Schubert, M., D. P. Brazil, D. J. Burks, J. A. Kushner, J. Ye, C. L. Flint, J. Farhang-Fallah, P. Dikkes, X. M. Warot, C. Rio, G. Corfas, and M. F. White. (2003). Insulin receptor substrate-2 deficiency impairs brain growth and promotes tau phosphorylation. $J$ Neurosci 23 (18):7084-92.

Schubert, M., D. Gautam, D. Surjo, K. Ueki, S. Baudler, D. Schubert, T. Kondo, J. Alber, N. Galldiks, E. Kustermann, S. Arndt, A. H. Jacobs, W. Krone, C. R. Kahn, and J. C. Bruning. (2004). Role for neuronal insulin resistance in neurodegenerative diseases. Proc Natl Acad Sci U S A 101 (9):3100-5. 
Schutt, B. S., M. Langkamp, U. Rauschnabel, M. B. Ranke, and M. W. Elmlinger. (2004). Integrin-mediated action of insulin-like growth factor binding protein-2 in tumor cells. J Mol Endocrinol 32 (3):859-68.

Seino, S., and G. I. Bell. (1989). Alternative splicing of human insulin receptor messenger RNA. Biochem Biophys Res Commun 159 (1):312-6.

Seino, S., M. Seino, S. Nishi, and G. I. Bell. (1989). Structure of the human insulin receptor gene and characterization of its promoter. Proc Natl Acad Sci U S A 86 (1):114-8.

Selkoe, D. J. (2004). Cell biology of protein misfolding: the examples of Alzheimer's and Parkinson's diseases. Nat Cell Biol 6 (11):1054-61.

Selman, C., S. Lingard, A. I. Choudhury, R. L. Batterham, M. Claret, M. Clements, F. Ramadani, K. Okkenhaug, E. Schuster, E. Blanc, M. D. Piper, H. Al-Qassab, J. R. Speakman, D. Carmignac, I. C. Robinson, J. M. Thornton, D. Gems, L. Partridge, and D. J. Withers. (2008). Evidence for lifespan extension and delayed age-related biomarkers in insulin receptor substrate 1 null mice. FASEB J 22 (3):807-18.

Sharfi, H., and H. Eldar-Finkelman. (2008). Sequential phosphorylation of insulin receptor substrate-2 by glycogen synthase kinase-3 and c-Jun NH2-terminal kinase plays a role in hepatic insulin signaling. Am J Physiol Endocrinol Metab 294 (2):E307-15.

Shechter, M., S. Ginsberg, M. Scheinowitz, M. S. Feinberg, and Z. Laron. (2007). Obese adults with primary growth hormone resistance (Laron Syndrome) have normal endothelial function. Growth Horm IGF Res 17 (2):165-70.

Sherrington, R., S. Froelich, S. Sorbi, D. Campion, H. Chi, E. A. Rogaeva, G. Levesque, E. I. Rogaev, C. Lin, Y. Liang, M. Ikeda, L. Mar, A. Brice, Y. Agid, M. E. Percy, F. ClergetDarpoux, S. Piacentini, G. Marcon, B. Nacmias, L. Amaducci, T. Frebourg, L. Lannfelt, J. M. Rommens, and P. H. St George-Hyslop. (1996). Alzheimer's disease associated with mutations in presenilin 2 is rare and variably penetrant. Hum Mol Genet 5 (7):985-8.

Siddle, K., M. A. Soos, C. E. Field, and B. T. Nave. (1994). Hybrid and atypical insulin/insulinlike growth factor I receptors. Horm Res 41 Suppl 2:56-64; discussion 65.

Sjogren, K., J. L. Liu, K. Blad, S. Skrtic, O. Vidal, V. Wallenius, D. LeRoith, J. Tornell, O. G. Isaksson, J. O. Jansson, and C. Ohlsson. (1999). Liver-derived insulin-like growth factor I (IGF-I) is the principal source of IGF-I in blood but is not required for postnatal body growth in mice. Proc Natl Acad Sci U S A 96 (12):7088-92.

Skovronsky, D. M., D. B. Moore, M. E. Milla, R. W. Doms, and V. M. Lee. (2000). Protein kinase C-dependent alpha-secretase competes with beta-secretase for cleavage of amyloidbeta precursor protein in the trans-golgi network. J Biol Chem 275 (4):2568-75.

Slee, E. A., D. J. O'Connor, and X. Lu. (2004). To die or not to die: how does p53 decide? Oncogene 23 (16):2809-18.

Sleegers, K., N. Brouwers, I. Gijselinck, J. Theuns, D. Goossens, J. Wauters, J. Del-Favero, M. Cruts, C. M. van Duijn, and C. Van Broeckhoven. (2006). APP duplication is sufficient to cause early onset Alzheimer's dementia with cerebral amyloid angiopathy. Brain 129 (Pt 11):2977-83.

Solinas, G., W. Naugler, F. Galimi, M. S. Lee, and M. Karin. (2006). Saturated fatty acids inhibit induction of insulin gene transcription by JNK-mediated phosphorylation of insulinreceptor substrates. Proc Natl Acad Sci U S A 103 (44):16454-9.

Sompol, P., W. Ittarat, J. Tangpong, Y. Chen, I. Doubinskaia, I. Batinic-Haberle, H. M. Abdul, D. A. Butterfield, and D. K. St Clair. (2008). A neuronal model of Alzheimer's disease: 
an insight into the mechanisms of oxidative stress-mediated mitochondrial injury. Neuroscience 153 (1):120-30.

Song, G., G. Ouyang, and S. Bao. (2005). The activation of Akt/PKB signaling pathway and cell survival. J Cell Mol Med 9 (1):59-71.

Sonntag, W. E., R. W. Steger, L. J. Forman, and J. Meites. (1980). Decreased pulsatile release of growth hormone in old male rats. Endocrinology 107 (6):1875-9.

Sontag, E., V. Nunbhakdi-Craig, G. Lee, G. S. Bloom, and M. C. Mumby. (1996). Regulation of the phosphorylation state and microtubule-binding activity of Tau by protein phosphatase 2A. Neuron 17 (6):1201-7.

Soos, M. A., and K. Siddle. (1989). Immunological relationships between receptors for insulin and insulin-like growth factor I. Evidence for structural heterogeneity of insulin-like growth factor I receptors involving hybrids with insulin receptors. Biochem J 263 (2):553-63.

Soos, M. A., J. Whittaker, R. Lammers, A. Ullrich, and K. Siddle. (1990). Receptors for insulin and insulin-like growth factor-I can form hybrid dimers. Characterisation of hybrid receptors in transfected cells. Biochem J 270 (2):383-90.

Soto, C. (2003). Unfolding the role of protein misfolding in neurodegenerative diseases. Nat Rev Neurosci 4 (1):49-60.

Sotthibundhu, A., A. M. Sykes, B. Fox, C. K. Underwood, W. Thangnipon, and E. J. Coulson. (2008). Beta-amyloid(1-42) induces neuronal death through the p75 neurotrophin receptor. J Neurosci 28 (15):3941-6.

St George-Hyslop, P., J. Haines, E. Rogaev, M. Mortilla, G. Vaula, M. Pericak-Vance, J. F. Foncin, M. Montesi, A. Bruni, S. Sorbi, and et al. (1992). Genetic evidence for a novel familial Alzheimer's disease locus on chromosome 14. Nat Genet 2 (4):330-4.

Stewart, C. E., and P. Rotwein. (1996). Growth, differentiation, and survival: multiple physiological functions for insulin-like growth factors. Physiol Rev 76 (4):1005-26.

Stewart, R., and D. Liolitsa. (1999). Type 2 diabetes mellitus, cognitive impairment and dementia. Diabet Med 16 (2):93-112.

Stokoe, D., L. R. Stephens, T. Copeland, P. R. Gaffney, C. B. Reese, G. F. Painter, A. B. Holmes, F. McCormick, and P. T. Hawkins. (1997). Dual role of phosphatidylinositol-3,4,5trisphosphate in the activation of protein kinase B. Science 277 (5325):567-70.

Stoothoff, W. H., and G. V. Johnson. (2005). Tau phosphorylation: physiological and pathological consequences. Biochim Biophys Acta 1739 (2-3):280-97.

Suh Y, Atzmon G, Cho MO, Hwang D, Liu B, Leahy DJ, Barzilai N, Cohen P. (2008). Functionally significant insulin-like growth factor I receptor mutations in centenarians. Proc Natl Acad Sci U S A 105(9):3438-3442.

Sun, X. J., P. Rothenberg, C. R. Kahn, J. M. Backer, E. Araki, P. A. Wilden, D. A. Cahill, B. J. Goldstein, and M. F. White. (1991). Structure of the insulin receptor substrate IRS-1 defines a unique signal transduction protein. Nature 352 (6330):73-7.

Svensson, J., M. Diez, J. Engel, C. Wass, A. Tivesten, J. O. Jansson, O. Isaksson, T. Archer, T. Hokfelt, and C. Ohlsson. (2006). Endocrine, liver-derived IGF-I is of importance for spatial learning and memory in old mice. J Endocrinol 189 (3):617-27.

Tabaton, M., and E. Tamagno. (2007). The molecular link between beta- and gamma-secretase activity on the amyloid beta precursor protein. Cell Mol Life Sci 64 (17):2211-8.

Taguchi, A., L. M. Wartschow, and M. F. White. (2007). Brain IRS2 signaling coordinates life span and nutrient homeostasis. Science 317 (5836):369-72. 
Taguchi, A., and M. F. White. (2008). Insulin-like signaling, nutrient homeostasis, and life span. Annu Rev Physiol 70:191-212.

Tang, E. D., G. Nunez, F. G. Barr, and K. L. Guan. (1999). Negative regulation of the forkhead transcription factor FKHR by Akt. J Biol Chem 274 (24):16741-6.

Tang, Z., R. Yu, Y. Lu, A. F. Parlow, and J. L. Liu. (2005). Age-dependent onset of liver-specific IGF-I gene deficiency and its persistence in old age: implications for postnatal growth and insulin resistance in LID mice. Am J Physiol Endocrinol Metab 289 (2):E288-95.

Tannenbaum, G. S., and J. B. Martin. (1976). Evidence for an endogenous ultradian rhythm governing growth hormone secretion in the rat. Endocrinology 98 (3):562-70.

Tanzi, R. E., J. F. Gusella, P. C. Watkins, G. A. Bruns, P. St George-Hyslop, M. L. Van Keuren, D. Patterson, S. Pagan, D. M. Kurnit, and R. L. Neve. (1987). Amyloid beta protein gene: cDNA, mRNA distribution, and genetic linkage near the Alzheimer locus. Science 235 (4791):880-4.

Tanzi, R. E., R. D. Moir, and S. L. Wagner. (2004). Clearance of Alzheimer's Abeta peptide: the many roads to perdition. Neuron 43 (5):605-8.

Tanzi, R. E., G. Vaula, D. M. Romano, M. Mortilla, T. L. Huang, R. G. Tupler, W. Wasco, B. T. Hyman, J. L. Haines, B. J. Jenkins, and et al. (1992). Assessment of amyloid betaprotein precursor gene mutations in a large set of familial and sporadic Alzheimer disease cases. Am J Hum Genet 51 (2):273-82.

Tatar, M., A. Bartke, and A. Antebi. (2003). The endocrine regulation of aging by insulin-like signals. Science 299 (5611):1346-51.

Tatar, M., A. Kopelman, D. Epstein, M. P. Tu, C. M. Yin, and R. S. Garofalo. (2001). A mutant Drosophila insulin receptor homolog that extends life-span and impairs neuroendocrine function. Science 292 (5514):107-10.

Toivonen, J. M., and L. Partridge. (2009). Endocrine regulation of aging and reproduction in Drosophila. Mol Cell Endocrinol 299 (1):39-50.

Trejo, J. L., E. Carro, and I. Torres-Aleman. (2001). Circulating insulin-like growth factor I mediates exercise-induced increases in the number of new neurons in the adult hippocampus. J Neurosci 21 (5):1628-34.

Trejo, J. L., M. V. Llorens-Martin, and I. Torres-Aleman. (2008). The effects of exercise on spatial learning and anxiety-like behavior are mediated by an IGF-I-dependent mechanism related to hippocampal neurogenesis. Mol Cell Neurosci 37 (2):402-11.

Tu, M. P., D. Epstein, and M. Tatar. (2002). The demography of slow aging in male and female Drosophila mutant for the insulin-receptor substrate homologue chico. Aging Cell 1 (1):75-80.

Ullrich, A., A. Gray, A. W. Tam, T. Yang-Feng, M. Tsubokawa, C. Collins, W. Henzel, T. Le Bon, S. Kathuria, E. Chen, and et al. (1986). Insulin-like growth factor I receptor primary structure: comparison with insulin receptor suggests structural determinants that define functional specificity. EMBO J 5 (10):2503-12.

Valentino, K. L., I. Ocrant, and R. G. Rosenfeld. (1990). Developmental expression of insulinlike growth factor-II receptor immunoreactivity in the rat central nervous system. Endocrinology 126 (2):914-20.

van der Horst, A., A. M. de Vries-Smits, A. B. Brenkman, M. H. van Triest, N. van den Broek, F. Colland, M. M. Maurice, and B. M. Burgering. (2006). FOXO4 transcriptional activity is regulated by monoubiquitination and USP7/HAUSP. Nat Cell Biol 8 (10):1064-73. 
Van Obberghen, E., M. Ksauga, A. Le Cam, J. A. Hedo, A. Itin, and L. C. Harrison. (1981). Biosynthetic labeling of insulin receptor: studies of subunits in cultured human IM-9 lymphocytes. Proc Natl Acad Sci U S A 78 (2):1052-6.

Vanhaesebroeck, B., K. Ali, A. Bilancio, B. Geering, and L. C. Foukas. (2005). Signalling by PI3K isoforms: insights from gene-targeted mice. Trends Biochem Sci 30 (4):194-204.

Vardy, E. R., P. J. Rice, P. C. Bowie, J. D. Holmes, P. J. Grant, and N. M. Hooper. (2007). Increased circulating insulin-like growth factor-1 in late-onset Alzheimer's disease. J Alzheimers Dis 12 (4):285-90.

Vassar, R. (2004). BACE1: the beta-secretase enzyme in Alzheimer's disease. J Mol Neurosci 23 (1-2):105-14.

Vassar, R., B. D. Bennett, S. Babu-Khan, S. Kahn, E. A. Mendiaz, P. Denis, D. B. Teplow, S. Ross, P. Amarante, R. Loeloff, Y. Luo, S. Fisher, J. Fuller, S. Edenson, J. Lile, M. A. Jarosinski, A. L. Biere, E. Curran, T. Burgess, J. C. Louis, F. Collins, J. Treanor, G. Rogers, and M. Citron. (1999). Beta-secretase cleavage of Alzheimer's amyloid precursor protein by the transmembrane aspartic protease BACE. Science 286 (5440):735-41.

Veldhuis, J. D., M. Bidlingmaier, S. M. Anderson, Z. Wu, and C. J. Strasburger. (2001). Lowering total plasma insulin-like growth factor I concentrations by way of a novel, potent, and selective growth hormone (GH) receptor antagonist, pegvisomant (B2036-peg), augments the amplitude of GH secretory bursts and elevates basal/nonpulsatile GH release in healthy women and men. J Clin Endocrinol Metab 86 (7):3304-10.

Veldhuis, J. D., D. M. Keenan, J. N. Bailey, A. Adeniji, J. M. Miles, R. Paulo, M. Cosma, and C. Soares-Welch. (2008). Estradiol supplementation in postmenopausal women attenuates suppression of pulsatile growth hormone secretion by recombinant human insulin-like growth factor type I. J Clin Endocrinol Metab 93 (11):4471-8.

Veldhuis, J. D., D. M. Keenan, J. N. Bailey, A. Adeniji, J. M. Miles, R. Paulo, M. Cosma, and C. Soares-Welch. (2009). Testosterone supplementation in older men restrains insulinlike growth factor's dose-dependent feedback inhibition of pulsatile growth hormone secretion. J Clin Endocrinol Metab 94 (1):246-54.

Vicario-Abejon, C., M. J. Yusta-Boyo, C. Fernandez-Moreno, and F. de Pablo. (2003). Locally born olfactory bulb stem cells proliferate in response to insulin-related factors and require endogenous insulin-like growth factor-I for differentiation into neurons and glia. J Neurosci 23 (3):895-906.

von Figura, K., and A. Hasilik. (1986). Lysosomal enzymes and their receptors. Annu Rev Biochem 55:167-93.

Walsh, D. M., A. Lomakin, G. B. Benedek, M. M. Condron, and D. B. Teplow. (1997). Amyloid beta-protein fibrillogenesis. Detection of a protofibrillar intermediate. J Biol Chem 272 (35):22364-72.

Walsh, D. M., and D. J. Selkoe. (2007). A beta oligomers - a decade of discovery. J Neurochem 101 (5):1172-84.

Wang, M. C., D. Bohmann, and H. Jasper. (2005). JNK extends life span and limits growth by antagonizing cellular and organism-wide responses to insulin signaling. Cell 121 (1):115-25. 
Wang, S., N. Tulina, D. L. Carlin, and E. J. Rulifson. (2007). The origin of islet-like cells in Drosophila identifies parallels to the vertebrate endocrine axis. Proc Natl Acad Sci U S A 104 (50):19873-8.

Wang, Z., K. A. Al-Regaiey, M. M. Masternak, and A. Bartke. (2006). Adipocytokines and lipid levels in Ames dwarf and calorie-restricted mice. J Gerontol A Biol Sci Med Sci 61 (4):323-31.

Weigert, C., A. M. Hennige, T. Brischmann, A. Beck, K. Moeschel, M. Schauble, K. Brodbeck, H. U. Haring, E. D. Schleicher, and R. Lehmann. (2005). The phosphorylation of Ser318 of insulin receptor substrate 1 is not per se inhibitory in skeletal muscle cells but is necessary to trigger the attenuation of the insulin-stimulated signal. J Biol Chem 280 (45):37393-9.

Werther, G. A., M. Abate, A. Hogg, H. Cheesman, B. Oldfield, D. Hards, P. Hudson, B. Power, K. Freed, and A. C. Herington. (1990). Localization of insulin-like growth factor-I mRNA in rat brain by in situ hybridization--relationship to IGF-I receptors. Mol Endocrinol 4 (5):773-8.

Werther, G. A., A. Hogg, B. J. Oldfield, M. J. McKinley, R. Figdor, and F. A. Mendelsohn. (1989). Localization and Characterization of Insulin-Like Growth Factor-I Receptors in Rat Brain and Pituitary Gland Using in vitro Autoradiography and Computerized Densitometry* A Distinct Distribution from Insulin Receptors. J Neuroendocrinol 1 (5):369-77.

Werther, G. A., V. Russo, N. Baker, and G. Butler. (1998). The role of the insulin-like growth factor system in the developing brain. Horm Res 49 Suppl 1:37-40.

White, M. F., and C. R. Kahn. (1994). The insulin signaling system. J Biol Chem 269 (1):1-4.

Wilczak, N., P. De Bleser, P. Luiten, A. Geerts, A. Teelken, and J. De Keyser. (2000). Insulin-like growth factor II receptors in human brain and their absence in astrogliotic plaques in multiple sclerosis. Brain Res 863 (1-2):282-8.

Willcox, B. J., T. A. Donlon, Q. He, R. Chen, J. S. Grove, K. Yano, K. H. Masaki, D. C. Willcox, B. Rodriguez, and J. D. Curb. (2008). FOXO3A genotype is strongly associated with human longevity. Proc Natl Acad Sci U S A 105 (37):13987-92.

Williams, A. D., M. Sega, M. Chen, I. Kheterpal, M. Geva, V. Berthelier, D. T. Kaleta, K. D. Cook, and R. Wetzel. (2005). Structural properties of Abeta protofibrils stabilized by a small molecule. Proc Natl Acad Sci U S A 102 (20):7115-20.

Wilmoth, J. R. (2000). Demography of longevity: past, present, and future trends. Exp Gerontol 35 (9-10):1111-29.

Wittmann, T., G. M. Bokoch, and C. M. Waterman-Storer. (2004). Regulation of microtubule destabilizing activity of Op18/stathmin downstream of Rac1. J Biol Chem 279 (7):6196203.

Wolkow, C. A., K. D. Kimura, M. S. Lee, and G. Ruvkun. (2000). Regulation of C. elegans lifespan by insulinlike signaling in the nervous system. Science 290 (5489):147-50.

Wortley, K. E., J. P. del Rincon, J. D. Murray, K. Garcia, K. Iida, M. O. Thorner, and M. W. Sleeman. (2005). Absence of ghrelin protects against early-onset obesity. J Clin Invest 115 (12):3573-8.

Yakar, S., J. L. Liu, B. Stannard, A. Butler, D. Accili, B. Sauer, and D. LeRoith. (1999). Normal growth and development in the absence of hepatic insulin-like growth factor I. Proc Natl Acad Sci U S A 96 (13):7324-9. 
Yakar, S., J. Setser, H. Zhao, B. Stannard, M. Haluzik, V. Glatt, M. L. Bouxsein, J. J. Kopchick, and D. LeRoith. (2004). Inhibition of growth hormone action improves insulin sensitivity in liver IGF-1-deficient mice. J Clin Invest 113 (1):96-105.

Yamaguchi, Y., J. S. Flier, A. Yokota, H. Benecke, J. M. Backer, and D. E. Moller. (1991). Functional properties of two naturally occurring isoforms of the human insulin receptor in Chinese hamster ovary cells. Endocrinology 129 (4):2058-66.

Yamanaka, Y., J. L. Fowlkes, E. M. Wilson, R. G. Rosenfeld, and Y. Oh. (1999). Characterization of insulin-like growth factor binding protein-3 (IGFBP-3) binding to human breast cancer cells: kinetics of IGFBP-3 binding and identification of receptor binding domain on the IGFBP-3 molecule. Endocrinology 140 (3):1319-28.

Yang, E., J. Zha, J. Jockel, L. H. Boise, C. B. Thompson, and S. J. Korsmeyer. (1995). Bad, a heterodimeric partner for Bcl-XL and Bcl-2, displaces Bax and promotes cell death. Cell 80 (2):285-91.

Yang, X. F., W. G. Beamer, H. Huynh, and M. Pollak. (1996). Reduced growth of human breast cancer xenografts in hosts homozygous for the lit mutation. Cancer Res 56 (7): 1509-11.

Yang, Z., W. Zhao, X. Zhang, R. Mu, Y. Zhai, L. Kong, and C. Chen. (2008). Impact of famine during pregnancy and infancy on health in adulthood. Obes Rev 9 Suppl 1:95-9.

Ye, P., J. Carson, and A. J. D'Ercole. (1995). In vivo actions of insulin-like growth factor-I (IGF-I) on brain myelination: studies of IGF-I and IGF binding protein-1 (IGFBP-1) transgenic mice. J Neurosci 15 (11):7344-56.

Ye, P., L. Li, R. G. Richards, R. P. DiAugustine, and A. J. D'Ercole. (2002). Myelination is altered in insulin-like growth factor-I null mutant mice. J Neurosci 22 (14):6041-51.

Yenush, L., and M.F.White MF. (1997). The IRS-signalling system during insulin and cytokine action. Bioessays 19(6):491-500

Yin, P., Q. Xu, and C. Duan. (2004). Paradoxical actions of endogenous and exogenous insulinlike growth factor-binding protein-5 revealed by RNA interference analysis. J Biol Chem 279 (31):32660-6.

Yuan, R., S. W. Tsaih, S. B. Petkova, C. Marin de Evsikova, S. Xing, M. A. Marion, M. A. Bogue, K. D. Mills, L. L. Peters, C. J. Bult, C. J. Rosen, J. P. Sundberg, D. E. Harrison, G. A. Churchill, and B. Paigen. (2009). Aging in inbred strains of mice: study design and interim report on median lifespans and circulating IGF1 levels. Aging Cell 8 (3):277-87.

Zha, J., H. Harada, K. Osipov, J. Jockel, G. Waksman, and S. J. Korsmeyer. (1997). BH3 domain of BAD is required for heterodimerization with BCL-XL and pro-apoptotic activity. $J$ Biol Chem 272 (39):24101-4.

Zhang, C. L., Y. Zou, W. He, F. H. Gage, and R. M. Evans. (2008). A role for adult TLX-positive neural stem cells in learning and behaviour. Nature 451 (7181):1004-7.

Zhang, S., K. Iwata, M. J. Lachenmann, J. W. Peng, S. Li, E. R. Stimson, Y. Lu, A. M. Felix, J. E. Maggio, and J. P. Lee. (2000). The Alzheimer's peptide a beta adopts a collapsed coil structure in water. J Struct Biol 130 (2-3):130-41.

Zhao, L., B. Teter, T. Morihara, G. P. Lim, S. S. Ambegaokar, O. J. Ubeda, S. A. Frautschy, and G. M. Cole. (2004). Insulin-degrading enzyme as a downstream target of insulin receptor signaling cascade: implications for Alzheimer's disease intervention. J Neurosci 24 (49):11120-6. 
Zigman, J. M., Y. Nakano, R. Coppari, N. Balthasar, J. N. Marcus, C. E. Lee, J. E. Jones, A. E. Deysher, A. R. Waxman, R. D. White, T. D. Williams, J. L. Lachey, R. J. Seeley, B. B. Lowell, and J. K. Elmquist. (2005). Mice lacking ghrelin receptors resist the development of diet-induced obesity. J Clin Invest 115 (12):3564-72. 


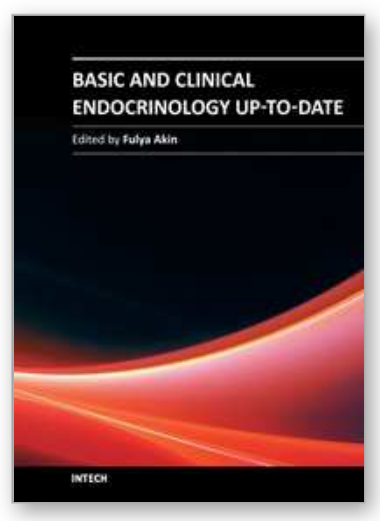

\author{
Basic and Clinical Endocrinology Up-to-Date \\ Edited by Dr. Fulya Akin
}

ISBN 978-953-307-340-8

Hard cover, 350 pages

Publisher InTech

Published online 17, October, 2011

Published in print edition October, 2011

This book provides the most up-to-date information on the basic and clinical aspects of endocrinology. It offers both researchers and clinicians experts, gold-standard analysis of endocrine research and translation into the treatment of diseases such as insulinoma, endocrine disease in pregnancy and steroid induced osteoporosis. Investigates both the endocrine functions of the kidneys and how the kidney acts as a target for hormones from other organ systems. Presents a uniquely comprehensive look at all aspects of endocrine changes in pregnancy and cardiovascular effects of androgens.

\title{
How to reference
}

In order to correctly reference this scholarly work, feel free to copy and paste the following:

Lorna Moll, Johanna Zemva and Markus Schubert (2011). Role of Central Insulin-Like Growth Factor-1 Receptor Signalling in Ageing and Endocrine Regulation, Basic and Clinical Endocrinology Up-to-Date, Dr. Fulya Akin (Ed.), ISBN: 978-953-307-340-8, InTech, Available from: http://www.intechopen.com/books/basicand-clinical-endocrinology-up-to-date/role-of-central-insulin-like-growth-factor-1-receptor-signalling-in-ageingand-endocrine-regulation

\section{INTECH}

open science | open minds

\section{InTech Europe}

University Campus STeP Ri Slavka Krautzeka 83/A 51000 Rijeka, Croatia Phone: +385 (51) 770447 Fax: +385 (51) 686166 www.intechopen.com

\section{InTech China}

Unit 405, Office Block, Hotel Equatorial Shanghai No.65, Yan An Road (West), Shanghai, 200040, China 中国上海市延安西路65号上海国际贵都大饭店办公楼405单元 Phone: +86-21-62489820

Fax: $+86-21-62489821$ 
(C) 2011 The Author(s). Licensee IntechOpen. This is an open access article distributed under the terms of the Creative Commons Attribution 3.0 License, which permits unrestricted use, distribution, and reproduction in any medium, provided the original work is properly cited. 